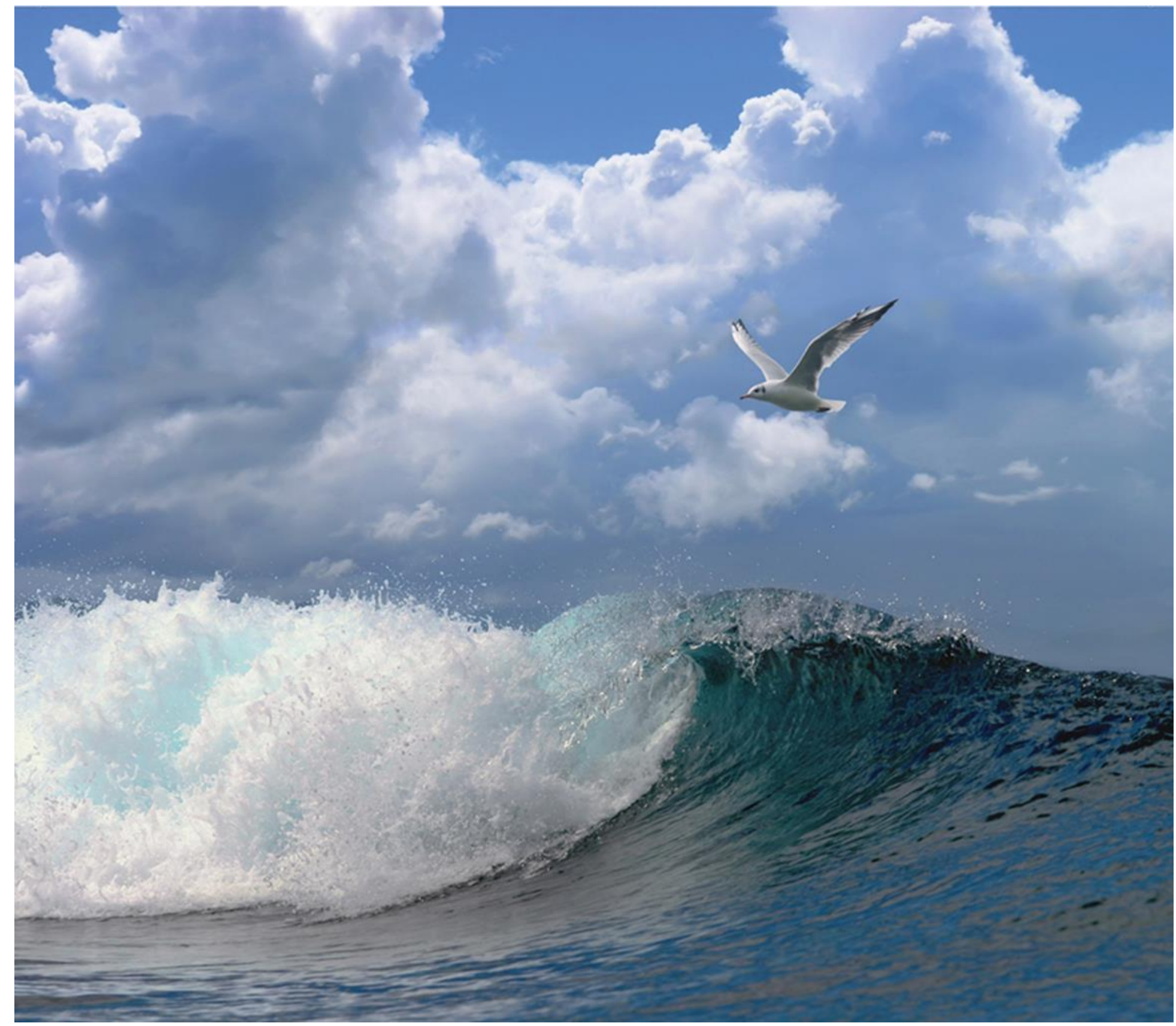

\title{
Slow Mill pilot Texel Voortoets Wet natuurbescherming
}




\section{Slow Mill pilot Texel \\ Voortoets Wet natuurbescherming}

Auteur(s): $\quad$ Ruud Jongbloed, Martijn Keur, Robbert Jak, Michaela Scholl

Wageningen Marine Research 
Keywords: golfslagenergieconverter, Wet natuurbescherming, Natura 2000, ecologische effecten natuurwaarden, stikstofdepositie

Opdrachtgever: NIOZ

Marcel van der Linden

Landsdiep 4

1797 SZ 't Horntje (Texel)

marcel.van.der.linden@nioz.nl

Namens deze:

Elias Consulting

Erwin Meijboom

erwin@eliasconsulting.nl

www.eliasconsulting. $\mathrm{nl}$

Dit rapport is gratis te downloaden van https://doi.org/10.18174/528931

Wageningen Marine Research verstrekt geen gedrukte exemplaren van rapporten.

Wageningen Marine Research is ISO 9001:2015 gecertificeerd.

(c) Wageningen Marine Research

Wageningen Marine Research, instituut binnen de rechtspersoon Stichting

Wageningen Research, hierbij

vertegenwoordigd door Drs. Ir. M.T. van

Manen, directeur bedrijfsvoering

KvK nr. 09098104,

WMR BTW nr. NL 8113.83.696.B16.

Code BIC/SWIFT address: RABONL2U

IBAN code: NL 73 RABO 0373599285
Wageningen Marine Research aanvaardt geen aansprakelijkheid voor gevolgschade, noch voor schade welke voortvloeit uit toepassingen van de resultaten van werkzaamheden of andere gegevens verkregen van Wageningen Marine Research. Opdrachtgever vrijwaart Wageningen Marine Research van aanspraken van derden in verband met deze toepassing.

Alle rechten voorbehouden. Niets uit deze uitgave mag weergegeven en/of gepubliceerd worden, gefotokopieerd of op enige andere manier gebruikt worden zonder schriftelijke toestemming van de uitgever of auteur. 


\section{Inhoud}

$\begin{array}{lr}\text { Samenvatting } & \mathbf{5}\end{array}$

$\begin{array}{llr}1 & \text { Inleiding } & 7\end{array}$

$\begin{array}{lll}1.1 & \text { Achtergrond } & 7\end{array}$

$\begin{array}{lll}1.2 & \text { Doel en toepassingsmogelijkheid van dit rapport } & 7\end{array}$

$\begin{array}{llc}1.3 & \text { Leeswijzer } & 8\end{array}$

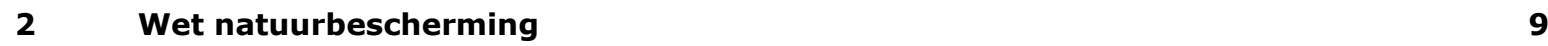

2.1 Beschermingsregime $\quad 9$

$\begin{array}{llr}2.2 & \text { Beschermingsbereik } & 10\end{array}$

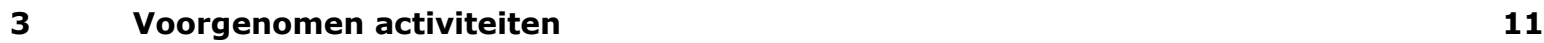

3.1 Beschrijving van plan-/studiegebied 11

3.2 Slow Mill-installatie $\quad 13$

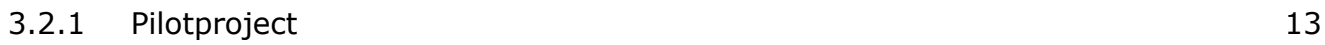

$\begin{array}{ll}3.2 .2 \text { Doorkijk } & 15\end{array}$

$\begin{array}{ll}3.3 & \text { Activiteitenbeschrijving } \\ \end{array}$

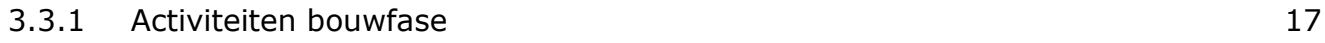

3.3.2 Activiteiten operationele fase 19

$\begin{array}{ll}\text { 3.3.3 Ontmantelingsfase } & 19\end{array}$

$\begin{array}{lll}3.4 & \text { Tijdsplanning } & 20\end{array}$

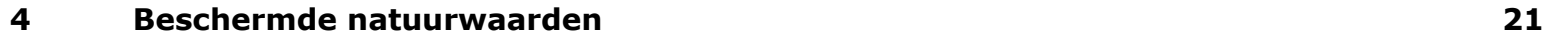

4.1 Natura 2000-gebied Noordzeekustzone 21

$\begin{array}{lll}4.1 .1 & \text { Beschermde natuurwaarden } & 21\end{array}$

4.1.2 Relevante beschermde natuurwaarden $\quad 22$

4.2 Natura 2000-gebied Duinen en Lage Land Texel 29

4.2.1 Beschermde natuurwaarden $\quad 29$

$\begin{array}{lll}\text { 4.2.2 Relevante beschermde natuurwaarden } & 29\end{array}$

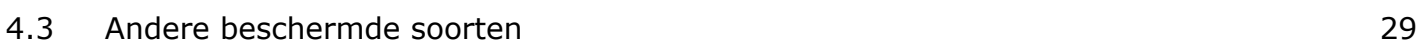

$\begin{array}{lll}4.3 .1 & \text { Vissen } & 30\end{array}$

$\begin{array}{lll}4.3 .2 \text { Vogels } & 30\end{array}$

$\begin{array}{lll}4.3 .3 & \text { Zoogdieren } & 30\end{array}$

$5 \quad$ Effectbeschrijving $\quad 31$

$\begin{array}{lll}5.1 & \text { Mogelijke verstoringsfactoren van de activiteiten } & 31\end{array}$

5.2 Mogelijke effecten o.b.v. literatuuronderzoek $\quad 32$

5.2.1 Botsingen en verstrikkingen $\quad 33$

5.2.2 Optische verstoring 33

$\begin{array}{lll}5.2 .3 & \text { Verstoring door geluid (boven water) } & 35\end{array}$

$\begin{array}{lll}5.2 .4 & \text { Verstoring door geluid (onder water) } & 35\end{array}$

5.2.5 Verandering golfslag 36

5.2.6 Verandering dynamiek substraat $\quad 36$

$\begin{array}{lll}5.2 .7 & \text { Introductie hard substraat } & 37\end{array}$

$\begin{array}{lll}5.2 .8 & \text { Vertroebeling } & 38\end{array}$

$\begin{array}{lll}5.2 .9 & \text { Verontreiniging (toxische stoffen) } & 38\end{array}$

5.2.10 Elektromagnetische straling 38

5.2.11 Stikstofdepositie $\quad 39$

5.2.12 Positieve effecten $\quad 39$ 
6.1 Temporele aanwezigheid 44

$\begin{array}{lll}6.2 & \text { Ruimtelijke aanwezigheid } & 47\end{array}$

6.3 Mogelijk optreden van effecten op habitattypen, soorten en hun $\begin{array}{ll}\text { instandhoudingsdoelstellingen } & 47\end{array}$

$\begin{array}{lll}\text { 6.3.1 Habitattypen } & 47\end{array}$

$\begin{array}{lll}\text { 6.3.2 Habitatrichtlijnsoorten } & 48\end{array}$

$\begin{array}{llr}7 & \text { Stikstofdepositie } & 50\end{array}$

8 Conclusies $\quad 52$

$9 \quad$ Kwaliteitsborging $\quad 53$

10 Literatur $\quad 54$

$\begin{array}{lr}\text { Verantwoording } & \mathbf{5 7}\end{array}$

Bijlage 1 Instandhoudingsdoelstellingen Natura 2000-gebied Noordzeekustzone 58

Bijlage 2 Instandhoudingsdoelstellingen Natura 2000-gebied Duinen en Lage Land $\begin{array}{ll}\text { Texel } & 60\end{array}$

Bijlage 3 Habitattypen van Natura 2000-gebieden Texel 62

Bijlage 4 Lijst van soorten die op bijlage IV van de habitatrichtlijn, bijlage II van Bern en/of bijlage I van Bonn staan

Bijlage 5 Lijst van waargenomen mariene soorten die op bijlage II, III en IV van de habitatrichtlijn staan

Bijlage 6 AERIUS ${ }^{\circledR}$-Calculator resultaten voor de verwachte stikstofuitstoot van de voorgenomen activiteiten 


\section{Samenvatting}

Initiatiefnemer Slow Mill Sustainable Power BV is voornemens om $4 \mathrm{~km}$ voor de Noordzeekust van Texel een pilot uit te voeren met de Slow Mill, een moderne 'watermolen' waarmee duurzame energie kan worden gewonnen uit de golfslag van de zee. De activiteiten die worden verricht in deze pilot betreffen: het installeren van de Slow Mill-converter aan een betonnen anker, het leggen van een elektriciteitskabel van de pilotlocatie naar strandpaal 20 (alternatief: paal 19) nabij De Koog, het testen van deze pilotinstallatie en de ontmanteling. De geprojecteerde doorlooptijd is vijf jaar.

Voor deze pilot met de Slow Mill dient de gebruikelijke vergunningprocedure voor activiteiten in Natura 2000-gebieden te worden doorlopen. Onderdeel van deze procedure is dat er een zogenaamde voortoets of een passende beoordeling wordt uitgevoerd, waarin op basis van de beschikbare kennis en informatie wordt getoetst of de beoogde activiteiten geen (wezenlijk) negatief effect hebben op de instandhoudingsdoelstellingen en daarmee de kernopgaven die in het aanwijzingsbesluit voor het of de betreffende Natura 2000-gebied(en) zijn geformuleerd.

Voor de Slow Mill-pilot heeft de initiatiefnemer ervoor gekozen om eerst een voortoets te laten uitvoeren. De activiteiten die gerelateerd zijn aan de Slow Mill-pilot, zijn geanalyseerd wat betreft de effecten op de instandhoudingsdoelstellingen, de habitats en soorten, van het Natura 2000-gebied Noordzeekustzone.

Ook is nagegaan of er externe werking kan optreden op het nabijgelegen Natura 2000-gebied Duinen en Lage Land Texel. Effecten op de instandhoudingsdoelen van dat Natura 2000-gebied worden uitgesloten geacht omdat de verstorende factoren van de projectactiviteiten, die zich dus buiten de begrenzing van dat gebied bevinden, niet zodanig doorwerken dat er blootstellingsniveaus worden bereikt waarbij effecten in het Natura 2000-gebied Duinen en Lage Land Texel te verwachten zijn. Hierbij wordt een uitzondering gemaakt voor de kleine mantelmeeuw van de broedkolonies op Texel, die ook foerageert voor de kust van De Koog en waarvoor (in het kader van deze voortoets) een effect niet op voorhand en met zekerheid kan worden uitgesloten.

Wave energy converters (WECs), waartoe ook de Slow Mill-pilotinstallatie behoort, zijn nog volop in ontwikkeling, met een beperkt aantal kleinschalige toepassingen. Er is nog maar weinig over eventuele effecten bekend waardoor er nog een grote mate van onzekerheid is over de potentiële effecten van WECs op het ecosysteem. Die onzekerheid leidt tot een voorzichtige benadering.

Wat betreft het Natura 2000-gebied Noordzeekustzone worden significante gevolgen van de Slow Millpilotinstallatie uitgesloten voor de volgende instandhoudingsdoelen:

- zeven habitattypen (H1110B, H1140B, H1310A, H1310B, H1330A, H2110, H2190B);

- drie broedvogelsoorten (bontbekplevier, strandplevier en dwergstern);

- twaalf niet-broedvogelsoorten (bergeend, topper, scholekster, kluut, bontbekplevier, zilverplevier, kanoet, drieteenstrandloper, bonte strandloper, rosse grutto, wulp en steenloper).

en kunnen significante gevolgen niet op voorhand worden uitgesloten voor:

- drie trekvissoorten (zeeprik, rivierprik en fint);

- drie zeezoogdiersoorten (gewone zeehond, grijze zeehond, bruinvis);

- $\quad$ zes niet-broedvogelsoorten (roodkeelduiker, parelduiker, aalscholver, eidereend, zwarte zeeeend en dwergmeeuw).

Voor de overige soorten die staan op bijlage IV van de habitatrichtlijn, bijlage II van Bern en/of bijlage I van Bonn (bijlage 4) én regelmatig in het studiegebied kunnen voorkomen, zijn de conclusies dat:

- effecten worden uitgesloten voor vijf vleermuissoorten (laatvlieger, gewone dwergvleermuis, noordse vleermuis, rosse vleermuis, ruige dwergvleermuis);

- $\quad$ potentieel negatieve effecten niet worden uitgesloten voor vier vissoorten (elft, houting, steur, zalm) en hun populaties. 
De totale uitstoot van de voorgenomen activiteiten van het Slow Mill-pilotproject op de relevante stikstofgevoelige Natura 2000-gebieden is in het jaar van de bouw 1,09 ton, in de operationele fase 0,37 ton per jaar en in het jaar van ontmanteling 0,08 ton. Over de duur van het gehele project (vijf jaar) is de totale berekende uitstoot 2,65 ton. Voor de Duinen en Lage Land van Texel levert dit een hoogste bijdrage op van 0,07 mol/ha/j. Voor de Natura 2000-gebieden Waddenzee en Duinen Den Helder-Callantsoog is de hoogste bijdrage $0,01 \mathrm{~mol} / \mathrm{ha} / \mathrm{j}$.

Een normtoetsing vindt uitsluitend door het bevoegd gezag plaats. 


\section{Inleiding}

\subsection{Achtergrond}

Initiatiefnemer Slow Mill Sustainable Power BV is voornemens om voor de Noordzeekust van het Waddeneiland Texel een pilot uit te voeren met een energieconverter waarmee duurzame energie kan worden gewonnen uit de golfslag van de zee. Hierbij gaat het om het installeren en testen van een full-scale model op $4 \mathrm{~km}$ voor de kust van Texel ter hoogte van strandpaal 19/20 en het leggen van de kabel voor het aanlanden van de opgewekte energie van de pilotlocatie naar strandpaal 20 (alternatief: 19). In de toekomst zou een golfenergiepark met zes converters kunnen ontstaan met een vermogen van in totaal 2,4 MW. De sterkte van de elektriciteitskabel voor de pilotinstallatie voorziet daar al in.

Voordat de proefopstelling kan worden gerealiseerd moeten de nodige milieuvergunningen worden verkregen. In het kader van de procedure volgens het Besluit Milieueffectrapportage (2018) moet een m.e.r.-beoordeling worden doorlopen. Hoewel de pilot geen ruimtelijk plan en geen complex besluit betreft, zal mogelijk een passende beoordeling (PB) ex Wet natuurbescherming (Wnb) moeten worden uitgevoerd omdat het project niet direct verband houdt met, of nodig is voor, het beheer van de onderhavige Natura 2000-gebieden.

Een PB is noodzakelijk wanneer niet bij voorbaat kan worden uitgesloten dat het initiatief afzonderlijk of in combinatie met andere projecten of plannen significante gevolgen kan hebben voor het betreffende gebied. Hier heeft de initiatiefnemer van het project ervoor gekozen om niet meteen een PB maar eerst een verkennende analyse, een zgn. voortoets, te laten uitvoeren.

\subsection{Doel en toepassingsmogelijkheid van dit rapport}

Dit rapport geeft de resultaten van de voortoets voor het project Slow Mill pilot Texel met één converter. Daarvoor zijn alle relevante aspecten van het project in kaart gebracht; vervolgens is beoordeeld welke ecologische effecten op de beschermde natuurwaarden te verwachten zijn.

Bij een voortoets worden drie mogelijke uitkomsten onderscheiden, die tot een ander vervolg leiden:

- de activiteiten hebben geen effect op de betrokken Natura 2000-gebieden $\rightarrow$ geen vervolg;

- als gevolg van de activiteiten treden mogelijk negatieve effecten op, maar deze zijn zeker niet significant $\rightarrow$ verstorings- en verslechteringstoets;

- $\quad$ als gevolg van de activiteiten treden mogelijk significant negatieve effecten op $\rightarrow$ Passende Beoordeling.

Aan de hand van dit rapport kan de initiatiefnemer in vooroverleg met het bevoegd gezag ${ }^{1}$ treden om het vervolgtraject zoals zich dat op basis van deze rapportage aftekent, nader te bepalen.

\footnotetext{
${ }^{1}$ Bevoegd gezag voor het verlenen van ontheffingen zijn de gedeputeerde staten van de provincie waarin een project valt (hier: NoordHolland). Voor het Natura 2000-gebied Noordzeekustzone geldt een specifieke regeling, nl. dat het ministerie van LNV het exclusieve bevoegd gezag is voor alle activiteiten in dat deel van dit gebied dat niet-provinciaal is ingedeeld.

(https://zoek.officielebekendmakingen.nl/stcrt-2013-11444.html; laatst geraadpleegd: augustus 2020). Het loket voor de aanvraag is de Rijksdienst voor Ondernemend Nederland (RVO), die tegenwoordig met een e-loket werkt.
} 


\subsection{Leeswijzer}

Voor de beoordeling is een indeling gekozen die tevens als leeswijzer dient. Na de inleiding (dit hoofdstuk) en een beknopte toelichting op de systematiek van de Wnb (hoofdstuk 2) worden de volgende onderdelen beschreven:

- de locatie, aard en planning van de projectactiviteiten (hoofdstuk 3)

- de relevante beschermde soorten en habitattypen (hoofdstuk 4)

- de relevante verstoringsfactoren en effecten van WECs en specifiek de Slow Mill-pilotinstallatie (hoofdstuk 5)

- de verwachte effecten van het project en een globale beoordeling ervan op de geïdentificeerde relevante beschermde soorten en habitattypen (hoofdstuk 6)

- de stikstofdepositie voor het meest aannemelijke scenario qua uitvoering van het project (hoofdstuk 7)

- de conclusies (hoofdstuk 8) 


\section{Wet natuurbescherming}

In dit hoofdstuk wordt een zeer beknopte toelichting gegeven op de Wet natuurbescherming $\left(\mathrm{Wnb}^{2}\right)$, de meest relevante begrippen en de systematiek die wordt gehanteerd in het kader van de vergunningverlening. Ook worden de betrokken Natura 2000-gebieden kort geïntroduceerd.

\subsection{Beschermingsregime}

De Wnb is de Nederlandse uitwerking van de richtlijnen 79/43/EEG van de Raad van de Europese Gemeenschappen van 2 april 1979 inzake het behoud van de vogelstand (Vogelrichtlijn; afgekort: VR) en 92/43/EEG van de Raad van de Europese Gemeenschappen van 21 mei 1992 inzake de instandhouding van de natuurlijke habitats en de wilde flora en fauna (Habitatrichtlijn; afgekort HR).

Bij de natuurwaarden die worden beschermd onder de Wnb gaat het om de bescherming van de dieren- en plantensoorten en gebieden waarvoor deze beide richtlijnen en de verdragen van Bonn en Bern voorschriften geven, aangevuld met andere soorten, die eveneens bescherming behoeven. De VR en HR (en dus ook de Wnb) kennen twee belangrijke beschermingsinstrumenten: het aanwijzen van zgn. speciale beschermingszones (SBZ; art. 4 VR) en de lijst met gebieden van communautair belang (art. $4 \mathrm{HR}$ ).

SBZ is de officiële naam voor een Natura 2000-gebied. De essentie van het beschermingsregime is dat voor deze gebieden instandhoudingsdoelstellingen worden vastgesteld die niet in gevaar mogen worden gebracht. Om dit te kunnen toetsen zijn projecten (en andere handelingen) die gevolgen kunnen hebben voor de soorten en habitats van de betreffende gebieden in beginsel vergunningplichtig.

Cruciaal is de aard en ernst van de eventuele effecten die van een project kunnen uitgaan. Wanneer significant negatieve gevolgen op de instandhoudingsdoelstellingen niet kunnen worden uitgesloten, kan slechts dan een vergunning worden verleend als er geen Alternatieven voor het project zijn, er Dwingende redenen van groot openbaar belang zijn, en Compenserende maatregelen worden genomen (kort: ADC-toets genoemd).

Allereerst moet daarom worden vastgesteld: zijn er negatieve effecten? Concreter: is er sprake van verstoring van soorten en/of een verslechtering van de kwaliteit van habitats of van habitats van soorten? Zo ja, dan is de volgende vraag: zijn die negatieve effecten significant?

Zoals reeds in paragraaf 1.2 geschetst zullen activiteiten die geen effect op de betrokken Natura 2000-gebieden hebben zonder vergunning doorgang kunnen vinden. Wanneer de analyse echter aangeeft dat er weliswaar negatieve effecten te verwachten zijn maar dat deze zeker niet significant zijn, kan worden volstaan met een zgn. verstorings- en verslechteringstoets op basis waarvan het bevoegd gezag de inschatting kan maken of de gevolgen inderdaad aanvaardbaar zijn. Wanneer niet met zekerheid kan worden uitgesloten dat er significant negatieve effecten optreden, moet het project aan een PB worden onderworpen. Bij de genoemde effecten kan het ook om effecten op Natura 2000gebieden gaan die buiten het plangebied liggen. Een plangebied hoeft niet per se zelf in een Natura 2000-gebied te liggen om toch effecten op een Natura 2000-gebied te kunnen hebben (externe werking).

Doorslaggevend is dus of een mogelijk negatief effect wel of niet significant kan zijn. Een activiteit heeft significante effecten wanneer daardoor de instandhoudingsdoelstellingen van een of meer betrokken Natura 2000-gebieden in gevaar worden gebracht. Aan het significantie-begrip moet een

\footnotetext{
2 De Wet natuurbescherming (Wnb) is sinds 1 januari 2017 van kracht en vervangt drie oude wetten: de Natuurbeschermingswet 1998, de Boswet en de Flora- en Faunawet.
} 
objectieve inhoud worden gegeven. Tegelijkertijd moet die inschatting gebaseerd zijn op de specifieke situatie die van toepassing is. De beoordeling wordt per effect gemaakt, maar ook de mogelijke opeenstapeling van effecten (cumulatie) moet onderzocht worden.

\subsection{Beschermingsbereik}

De bescherming van natuurwaarden valt uiteen in de bescherming van soorten en van gebieden (habitats).

\section{Soortenbescherming}

De bescherming van soorten heeft betrekking op de volgende dieren:

- alle van nature in Nederland in het wild levende vogels, zoals bedoeld in art. 1 van de VR

- in het wild levende dieren van bijlage IV onderdeel a bij de HR

- in het wild levende dieren van bijlage II bij het Verdrag van Bern

- in het wild levende dieren van bijlage I bij het Verdrag van Bonn

- de eieren, voortplantingsplaatsen of rustplaatsen van hierboven bedoelde dieren

Het betreft:

\begin{tabular}{|l|l|}
\hline Soortgroep & Soorten \\
\hline Vissen & Elft, fint, houting, steur, zalm, rivierprik, zeeprik (bijlage 4, bijlage 5) \\
\hline Vogels & Zo goed als alle soorten: zie lijsten (bijlage 4, bijlage 5) \\
\hline Vleermuizen & Zo goed als alle soorten: zie lijsten (bijlage 4, bijlage 5) \\
\hline Zeezoogdieren & Zo goed als alle soorten: zie lijsten (bijlage 4, bijlage 5) \\
\hline
\end{tabular}

Lijsten met alle soorten zijn in te zien via de link $h t t p: / / m i n e z . n e d e r l a n d s e s o o r t e n . n l / c o n t e n t / w e t-$ natuurbescherming-16-december-2015-paragraaf-32-beschermingsregime-soorten-van-de .

\section{Gebiedsbescherming}

Beschermd zijn de door Nederland aangewezen Natura 2000-gebieden. Voor het onderhavige Slow Mill-pilotproject zijn de relevante Natura 2000-gebieden: Noordzeekustzone en - vanwege de mogelijke externe werking van projectactiviteiten op extern gelegen beschermingsgebieden - ook het Natura 2000-gebied Duinen en Lage Land Texel. Voor de stikstofberekening komen daar de Natura 2000-gebieden Duinen Den Helder-Callantsoog en Waddenzee (automatisch) nog bij.

Gedetailleerde beschrijvingen van de kenmerken van de onderhavige Natura 2000-gebieden en de te beschermen habitattypen, habitatsoorten en vogelsoorten zijn te vinden in hoofdstuk 4 van dit rapport waarin onder andere informatie is verwerkt van de volgende webpagina's:

- Kaartenbijlage Natura 2000-beheerplan Noordzeekustzone Periode 2016-2022; https://www.rwsnatura2000.nl/gebieden/noordzeekustzone/nzkz_documenten/default.aspx

- Actuele documenten en kaarten met betrekking tot de aanwijzing van het Natura 2000-gebied Noordzeekustzone; https://www.natura2000.nl/gebieden/fries/and/noordzeekustzone

- Actuele documenten en kaarten met betrekking tot de aanwijzing van het Natura 2000-gebied Duinen en lage land Texel; https://www.natura2000.nl/gebieden/noord-holland/duinen-enlage-land-texel

- [website van alle Nederlandse provincies]; https://www.bij12.nl/onderwerpen/natuur-enlandschap/natura-2000-beheerplannen/2-duinen-en-lage-land-texel/

\section{Algemene verplichting Wnb}

In de Wnb is ook een algemene zorgplicht opgenomen die inhoudt dat planten en dieren (en hun directe leefomgeving) niet onnodig vernield/gedood of verstoord mogen worden. De focus ligt hierbij op individuele dieren en niet de natuurdoelen op een hoger niveau: het populatieniveau van een beschermde soort. De initiatiefnemer is dus verantwoordelijk voor een adequate naleving van deze algemene zorgplicht tijdens de uitvoering van de werkzaamheden. 


\section{Voorgenomen activiteiten}

In dit hoofdstuk wordt een beschrijving gegeven van het plangebied, de voorgenomen projectactiviteiten en de tijdsplanning voor het Slow Mill-pilotproject. Voor het beschrijven van de activiteiten wordt informatie gebruikt uit het projectplan Slow Mill pilot Texel en extra informatie zoals namens de initiatiefnemer is aangeleverd door Elias Consulting.

\subsection{Beschrijving van plan-/studiegebied}

De Slow Mill-pilotinstallatie komt ca. 4 km uit de kust van Texel ter hoogte van paal 19/20, zie figuur 1. Deze locatie valt binnen de grenzen van het Natura 2000-gebied Noordzeekustzone. Daarnaast wordt vanaf de installatie op zee een elektriciteitskabel getrokken die bij paal 20 (of eventueel paal 19) aan land komt en daar aan het bestaande elektriciteitsnet wordt gekoppeld. De beide aanlandlocaties op het strand liggen net als de installatie op zee, in het Natura 2000-gebied Noordzeekustzone en op zo'n 200-300 m van het Natura 2000-gebied Duinen en Lage Land Texel af; zie figuur 2 en 3 . Alle onderdelen van de Slow Mill-pilotinstallatie, inclusief het anker, worden van de Kooyhaven in Den Helder versleept naar de projectlocatie.

Voor de onderhavige voortoets is het van belang om twee gebieden te onderscheiden, namelijk het plangebied en het studiegebied. Deze worden als volgt gedefinieerd:

- Plangebied (projectgebied): het gebied rondom de Slow Mill-pilotinstallatie en de bekabeling, waar de voorgenomen projectactiviteiten zullen worden uitgevoerd.

- $\quad$ Studiegebied (onderzoeksgebied): het gebied dat wordt beschouwd voor de beoordeling van mogelijke effecten op habitattypen en -soorten. De grootte van dit gebied wordt bepaald door de reikwijdte (afstand) van de gevolgen. Deze worden behandeld in hoofdstuk 6 . Het is belangrijk op te merken dat de reikwijdte sterk kan verschillen per verstoringsfactor: optische verstoring, bovenwatergeluid, onderwatergeluid, elektromagnetische straling, etc.. Voor de begrenzing van het studiegebied kan een afstand van $5 \mathrm{~km}$ tot de Slow Mill-pilotinstallatie en de kabels worden aangehouden als maximale verstoringsafstand voor onderwatergeluid en stikstofdepositie op land. Deze inschatting is gebaseerd op de studie naar verstoring van zeezoogdieren door vaaractiviteiten van werkschepen (Pondera Consult, 2018) en een eigen zeer globale schatting van de stikstofemissie met bijbehorende depositie. Deze ruim geachte begrenzing van het studiegebied is indicatief; de werkelijke reikwijdte van effecten kan beperkter blijken te zijn. 


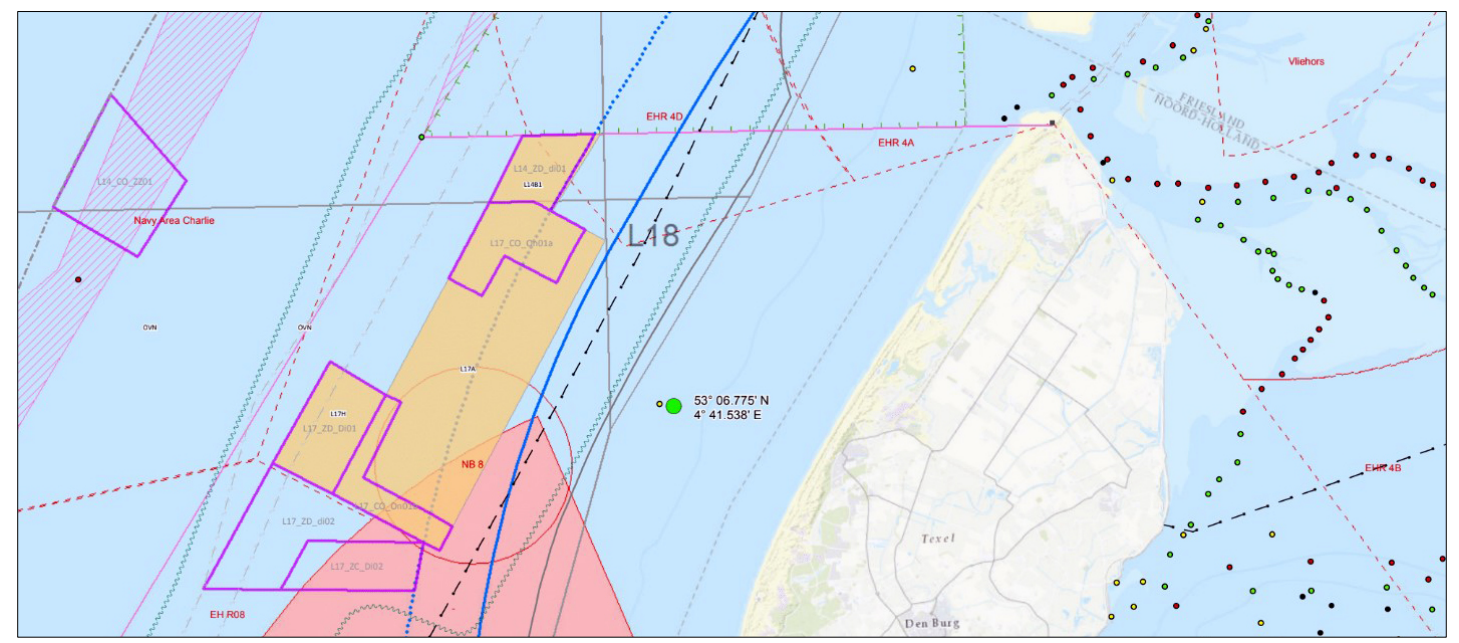

Figuur 1 Locatie van de Slow Mill-pilotinstallatie (groene stip) ter hoogte van De Koog (Texel); bron (via Elias Consulting): watervergunning RWS

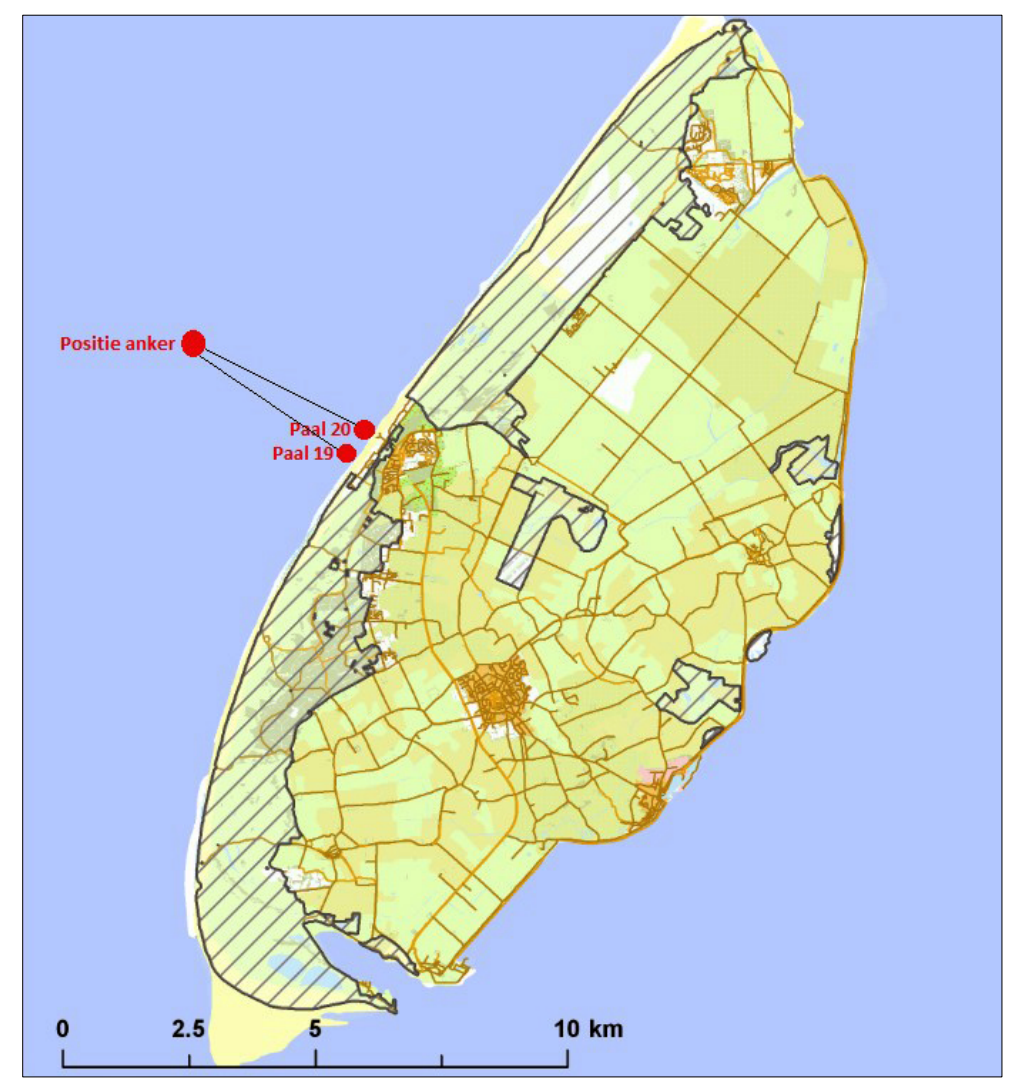

Figuur 2 Kaart van Texel met de positie van (het anker van) de Slow Mill-pilotinstallatie en de beide opties voor het kabeltracé met de aanlandingslocaties bij paal 20 (alternatief: paal 19). Het Natura 2000-gebied Duinen en Lage Land Texel is grijs gearceerd.; bron kaart:

https://nl.wikipedia.org/wiki/Bestand:Natura2000_-_Duinen_en_Lage_Land_Texel.png 


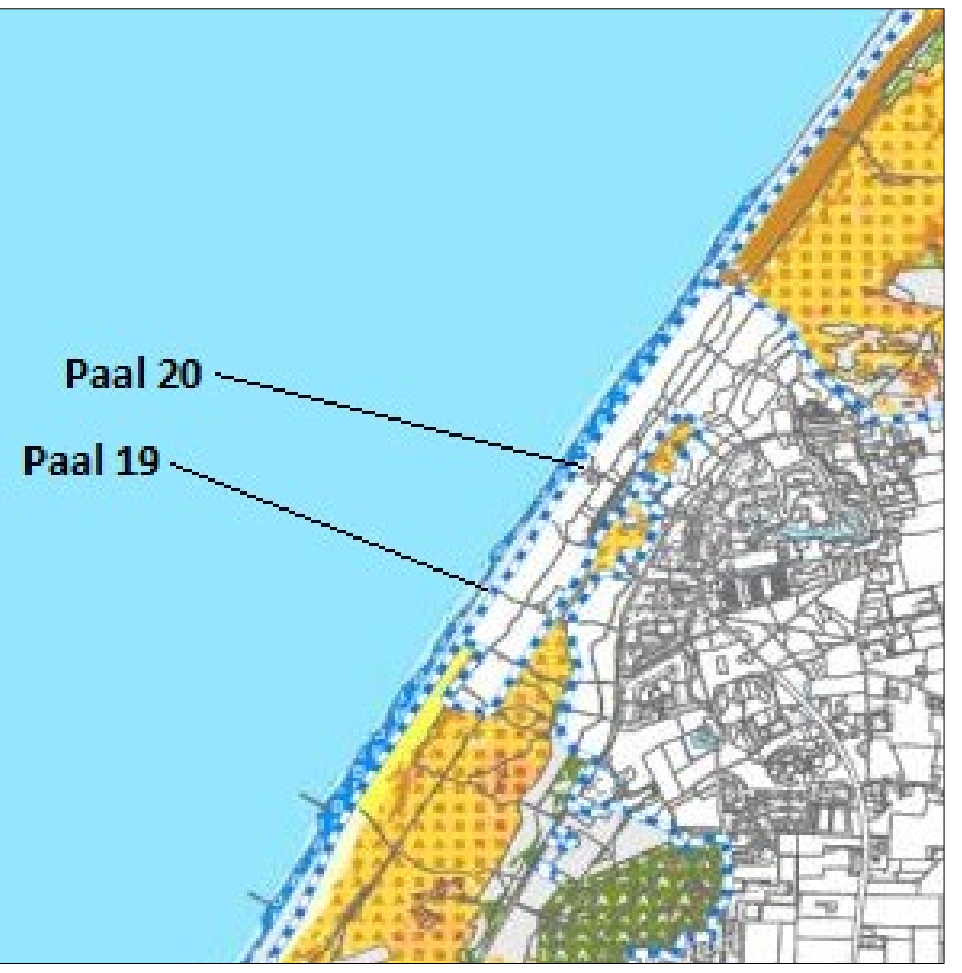

Figuur 3 Deel van het plangebied. Blauwe stippellijn: begrenzing van Natura 2000-gebied Duinen en Lage Land Texel. Aangeduid: de mogelijke aanlandlocaties voor de elektriciteitskabel bij paal 20 (alternatief: paal 19). Bron (kaart): https://nl.wikipedia.org/wiki/Lage_Land_van_Texel

\subsection{Slow Mill-installatie}

\subsubsection{Pilotproject}

De Slow Mill (de converter zelf) is een zogenaamde heave-and-surge golfenergieconverter. Dit is een nieuw type golfenergieconverter. Reeds bestaande converters worden geschaard onder de Engelse termen: point-absorbers, attentuators, oscillating water column terminators of overtopping devices). De Slow Mill-converter heeft een horizontale drijver die net boven het water uitkomt en dwars daarop een verticale drijver, die met een cilinder en zuigerstang verbonden is aan de horizontale drijver (zie figuur 4). Onder de horizontale drijver bevinden zich twee bladsystemen. De Slow Mill-converter is aan de onderzijde verbonden aan een anker (zie figuur 5) dat op de zeebodem staat. De hoogte van de converter vanaf het draaipunt op het anker, inclusief de horizontale drijver is circa $15 \mathrm{~m}$.

De Slow Mill-installatie maakt gebruik van de golven door in resonantie met de golf zowel de op- als neergaande bewegingen van de golf in een cirkelbeweging om te zetten in een verticale beweging in de cilinder, die een $400 \mathrm{~kW}$-generator aandrijft in de horizontale drijver. De opgewekte energie kan worden opgeslagen in een opslagbuffer en daarna via de elektriciteitskabel worden geleverd naar land. Bewegende delen onder water zijn slechts twee onderdelen: het scharnier tussen het anker en de zuigerstang van de Slow Mill-converter. Er vindt geen onderhoud onder water plaats. Voor inspectie en vervanging van de (bewegende) delen wordt de Slow Mill-installatie aan het wateroppervlak gebracht door lucht in het anker te blazen zodat het geheel gaat drijven. Daarvoor wordt de kabel, voordat die de zeebodem ingaat, in een lus, maximaal $5 \mathrm{~m}$ van het anker vandaan, bovenop de zeebodem gelegd. Eventueel wordt deze lus verzwaard zodat er geen losse delen in de waterkolom zweven.

Voor de Slow Mill-pilotinstallatie wordt geen aangroei-remmende coating gebruikt. Wel zullen de zes bladen elk met een andere anti-fouling-maatregel worden getest. Daarbij zal geen chemische of zgn. zelfslijpende antifouling worden toegepast. Bij de maatregelen gaat het om:

- $\quad$ Elektrische anti-fouling (current spikes)

- Spuitkoppen

- Wrapping folie

- Micro-haartjes (finsulate) 
- UV-led

- Akoestisch

- Wissers

- Referentieblad (geen anti-fouling)

Uit oogpunt van veiligheid zal rondom de Slow Mill-pilotinstallatie in een veiligheidszone moeten worden voorzien waarin geen andere activiteiten plaatsvinden (milieuzonering). De initiatiefnemer acht daarvoor een gebied met een straal van circa 20-30 m, voldoende. Hieraan ligt de berekening van het ruimtebeslag door de installatie ten grondslag (hoogte van de Slow Mill: $15 \mathrm{~m}$; draaicirkel bij 45 graden: circa sinus 45 graden $* 15 \mathrm{~m}=10,6 \mathrm{~m}$ ) waaraan een extra marge is toegevoegd.

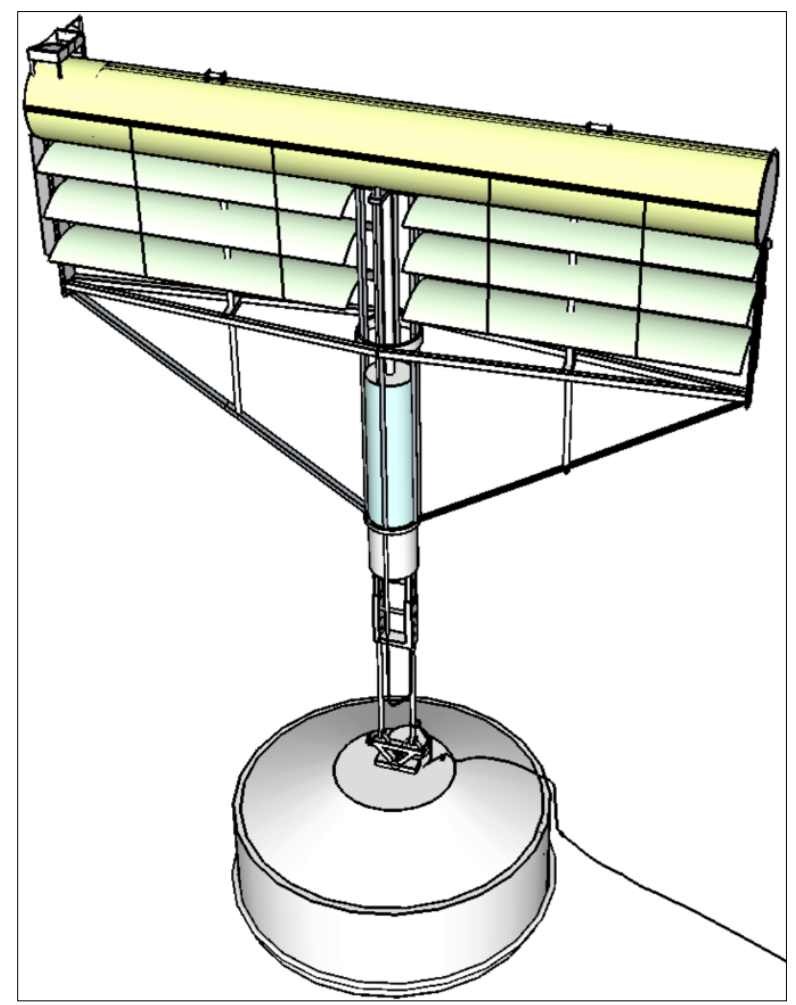

Figuur 4 Prototype Slow Mill-pilotinstallatie, inclusief anker en kabelaansluiting. De hoogte gemeten vanaf het draaipunt op het anker is circa $15 \mathrm{~m}$. Bron: Slow Mill Sustainable Power BV

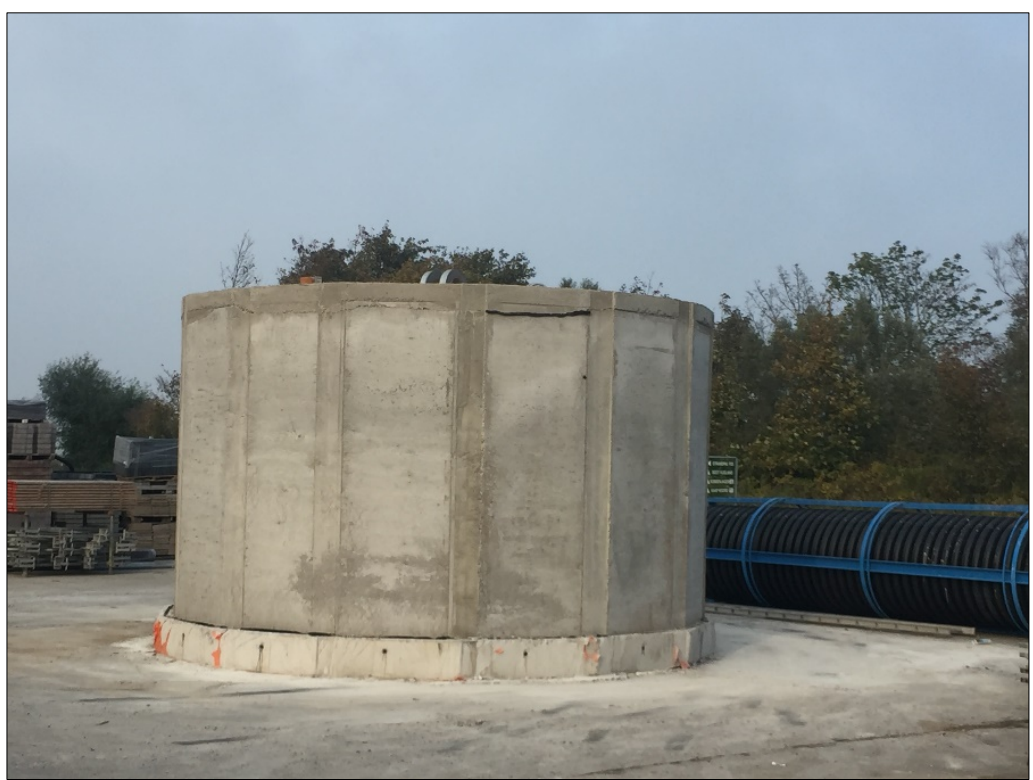

Figuur 5 Betonnen anker voor de Slow Mill-pilotinstallatie. Bron: Slow Mill Sustainable Power BV 


\subsubsection{Doorkijk}

Deze voortoets richt zich op het pilotproject: de Slow Mill-pilotinstallatie met één converter. Om alvast een doorkijk te geven van de mogelijkheden in de toekomst, wordt in figuur 6 een parkopstelling getoond. Daarin zijn vijf converters te zien maar het idee is om een park met zes converters te realiseren, die versprongen zijn opgesteld en een totale vermogen van 2,4 MW hebben. Als na de geprojecteerde doorlooptijd van de pilot (vijf jaar) voor uitbreiding met meerdere converters worden gekozen, zal de Slow Mill-converter van het pilotproject niet worden ontmanteld maar daar onderdeel van uitmaken.

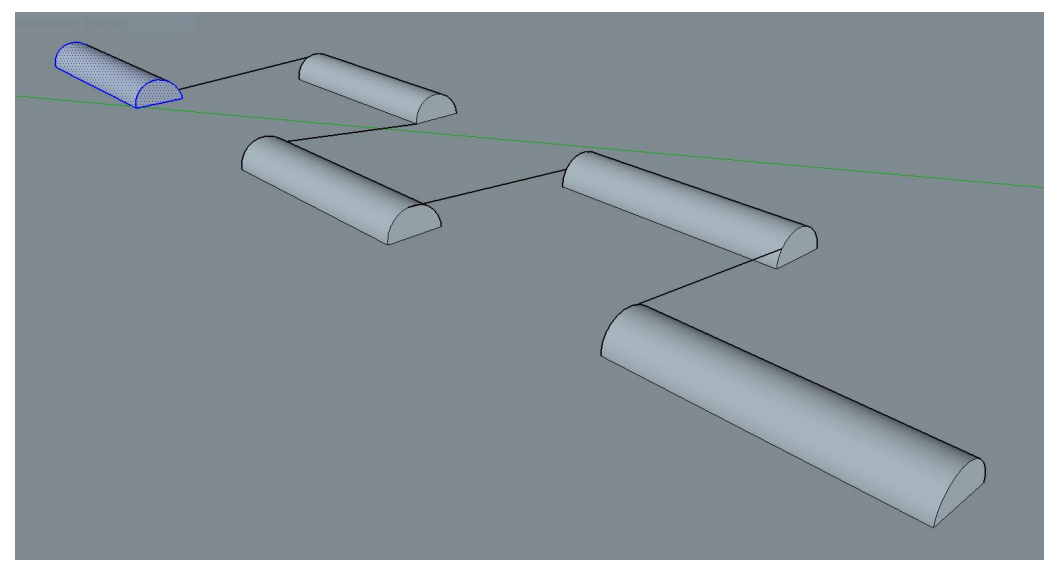

Figuur 6 Impressie van een parkopstelling met meerdere Slow Mill-converters. Getoond zijn de horizontale drijvers aan het wateroppervlak. Bron: Slow Mill Sustainable Power BV

\subsection{Activiteitenbeschrijving}

Voor de voortoets van het Slow Mill-pilotproject worden drie fases onderscheiden omdat de samenstelling, aard en omvang van de activiteiten in elke fase anders (kunnen) zijn, waardoor ook de effecten, afzonderlijk of in combinatie, verschillend kunnen doorwerken. In de bouw- en ontmantelingsfase zullen de activiteiten over het algemeen relatief kort van duur zijn, terwijl de activiteiten in de operationele fase aanhoudend of frequenter zijn, wat over de hele projectperiode gerekend een grotere milieubelasting kan geven, maar bij dieren ook de kans op gewenning aan de verstoringsbron kan betekenen.

\section{Bouwfase}

- Plaatsen elektriciteitskabels (in zee en via strand/duinen naar aansluitpunt met bestaande elektriciteitsnet)

- Graafwerkzaamheden

- Vaarwerkzaamheden

- $\quad$ Plaatsen van het anker

- Vaarwerkzaamheden

- Plaatsen van de Slow Mill-converter

- Vaarwerkzaamheden

- Inregelen installatie

- Vaarwerkzaamheden

Operationele fase

- Slow Mill-pilotinstallatie in bedrijf

- Preventief en correctief onderhoud en onderzoek

- Vaarwerkzaamheden

Ontmantelingsfase

- Opruimen Slow Mill-pilotinstallatie (alle onderdelen, inclusief kabel)

- Vaarwerkzaamheden 
In de volgende paragrafen en tabel 1 wordt gedetailleerde uitleg gegeven van iedere individuele activiteit, inclusief de frequentie, periode van uitvoering en welke schepen daarbij gebruikt zullen worden. Alle activiteiten worden overdag uitgevoerd.

Tabel 1 De voorziene activiteiten in de bouwfase, operationele fase en ontmantelingsfase van de Slow Mill-pilotinstallatie, met frequentie, duur/tijdstip van de dag, uitvoeringsperiode en benodigd transportmiddel.

\begin{tabular}{|c|c|c|c|c|c|}
\hline Activiteit & Toelichting & $\begin{array}{l}\text { Frequentie } \\
\text { (totale periode } \\
=5 \text { jaar) }\end{array}$ & Duur en tijdstip & $\begin{array}{l}\text { Uitvoerings- } \\
\text { periode }\end{array}$ & $\begin{array}{l}\text { Transportmiddel/ } \\
\text { materieel }\end{array}$ \\
\hline \multicolumn{6}{|l|}{ Bouwfase } \\
\hline $\begin{array}{l}\text { Vaarwerkzaamheden } \\
\text { tbv pilotinstallatie }\end{array}$ & $\begin{array}{l}\text { Diverse transporten van } \\
\text { Kooyhaven naar Slow } \\
\text { Mill-locatie in zee } 4 \mathrm{~km} \\
\text { uit de kust ter hoogte } \\
\text { van De Koog tbv } \\
\text { montage-/onderhouds- } \\
\text { /en testwerkzaamheden } \\
\text { (inregelen installatie) }\end{array}$ & 30 keer per jaar & 1 dag, overdag & maart-aug & $\begin{array}{l}\text { The Empiric } 12 \mathrm{~m}, \\
190 \text { pk diesel }\end{array}$ \\
\hline Plaatsen anker & $\begin{array}{l}\text { Betonnen anker } 12 \mathrm{~m} \\
\text { afzinken }\end{array}$ & eenmalig & 1 dag, overdag & maart-aug & $\begin{array}{l}\text { The Empiric } 12 \text { m, } \\
190 \text { pk diesel }\end{array}$ \\
\hline $\begin{array}{l}\text { Graaf- en } \\
\text { vaarwerkzaamheden tbv } \\
\text { elektriciteitskabel in zee }\end{array}$ & $\begin{array}{l}\text { Kabel } 50 \text { mm op 2-3 m } \\
\text { diepte ingraven in de } \\
\text { zeebodem, vanaf de } \\
\text { locatie in zee tot de } \\
\text { aanlandlocatie (paal 20; } \\
\text { alternatief 19) }\end{array}$ & eenmalig & $\begin{array}{l}3 \text { dagen met rustig } \\
\text { weer }\end{array}$ & maart-aug & $\begin{array}{l}\text { offshore support } \\
\text { vessel RAM } 57 \text { m } \\
600 \text { pk diesel, }\end{array}$ \\
\hline $\begin{array}{l}\text { Graafwerkzaamheden tbv } \\
\text { elektriciteitskabel in } \\
\text { strand/duin }\end{array}$ & $\begin{array}{l}\text { Kabel ingraven in strand } \\
\text { en door de duinen naar } \\
\text { aansluitpunt op } \\
\text { elektriciteitsnet ( } 200 \mathrm{~m} \\
\text { tot parkeerplaats, of } 400 \\
\text { m tot bebouwde kom) }\end{array}$ & eenmalig & $\begin{array}{l}3 \text { dagen met rustig } \\
\text { weer }\end{array}$ & maart-aug & $\begin{array}{l}\text { Graafmachine, } \\
\text { diesel, } 250 \text { pk }\end{array}$ \\
\hline $\begin{array}{l}\text { Vaarwerkzaamheden tbv } \\
\text { Slow Mill-converter }\end{array}$ & $\begin{array}{l}\text { Slow Mill slepen naar } \\
\text { anker }\end{array}$ & 2 keer per jaar & 1 dag, overdag & maart-aug & $\begin{array}{l}\text { The Empiric } 12 \mathrm{~m}, \\
190 \text { pk diesel }\end{array}$ \\
\hline $\begin{array}{l}\text { Plaatsen Slow Mill- } \\
\text { converter }\end{array}$ & $\begin{array}{l}\text { Anker ophalen, Slow Mill- } \\
\text { converter koppelen aan } \\
\text { anker, anker weer laten } \\
\text { afzinken }\end{array}$ & 3 keer per jaar & 1 dag, overdag & maart-aug & $\begin{array}{l}\text { The Empiric } 12 \mathrm{~m}, \\
190 \text { pk diesel }\end{array}$ \\
\hline \multicolumn{6}{|l|}{ Operationele fase } \\
\hline Slow Mill-pilotinstallatie & In bedrijf & $\begin{array}{l}\text { continu muv } \\
\text { onderhouds } \\
\text { periodes }\end{array}$ & 5 jaar & jan-dec & $\begin{array}{l}\text { Slow Mill 400, } \\
\text { potentieel } \\
\text { vermogen } 400 \mathrm{~kW}\end{array}$ \\
\hline $\begin{array}{l}\text { Vaarwerkzaamheden tbv } \\
\text { onderhoud }\end{array}$ & $\begin{array}{l}\text { Varen onderhouds- } \\
\text { platform van Kooyhaven } \\
\text { naar locatie op zee voor } \\
\text { gepland onderhoud }\end{array}$ & 15 keer per jaar & 1 dag, overdag & jan-dec & $\begin{array}{l}\text { The Empiric } 12 \mathrm{~m}, \\
190 \text { pk diesel }\end{array}$ \\
\hline \multicolumn{6}{|l|}{ Ontmantelingsfase } \\
\hline $\begin{array}{l}\text { Opruimen Slow Mill- } \\
\text { converter }\end{array}$ & $\begin{array}{l}\text { Anker omhoog blazen, } \\
\text { Slow Mill loskoppelen }\end{array}$ & eenmalig & 1 dag, overdag & maart-aug & $\begin{array}{l}\text { The Empiric } 12 \mathrm{~m}, \\
190 \text { pk diesel }\end{array}$ \\
\hline Vaarwerkzaamheden & $\begin{array}{l}\text { Anker en Slow Mill- } \\
\text { converter naar } \\
\text { Kooyhaven slepen }\end{array}$ & eenmalig & 1 dag, overdag & maart-aug & $\begin{array}{l}\text { The Empiric } 12 \mathrm{~m}, \\
190 \text { pk diesel }\end{array}$ \\
\hline $\begin{array}{l}\text { Opruimen kabel van/uit } \\
\text { zeebodem }\end{array}$ & $\begin{array}{l}\text { Lostrekken kabel en } \\
\text { verwijderen }\end{array}$ & eenmalig & 1 dag, overdag & maart-aug & $\begin{array}{l}\text { offshore support } \\
\text { vessel RAM } 57 \text { m } \\
600 \text { pk diesel, }\end{array}$ \\
\hline $\begin{array}{l}\text { Opruimen kabel van } \\
\text { strand/duin }\end{array}$ & $\begin{array}{l}\text { Lostrekken kabel en } \\
\text { verwijderen }\end{array}$ & eenmalig & 1 dag, overdag & maart-aug & $\begin{array}{l}\text { Graafmachine, } \\
\text { diesel, } 250 \text { pk }\end{array}$ \\
\hline
\end{tabular}




\subsubsection{Activiteiten bouwfase}

In de bouwfase zijn er drie activiteiten ten behoeve van het realiseren van de pilotinstallatie (voor de uitvoering in de tijd zie paragraaf 3.4):

- Plaatsen van het anker

- Plaatsen elektriciteitskabel in zee en strand en door de duinen

- Plaatsen van de Slow Mill-converter

- Inregelen installatie

Deze activiteiten gaan gepaard met vaar- en graafwerkzaamheden.

\subsubsection{Plaatsen van het anker}

Op de pilotlocatie (figuur 1) wordt in april 2021 eenmalig een betonnen anker van circa $12 \mathrm{~m}$ doorsnee geplaatst (figuur 5). Het anker wordt met een installatieplatform vanuit de Kooyhaven in Den Helder naar de testlocatie in zee gesleept (figuur 7). Dit platform, The Empiric, heeft een 190 pk dieselmotor. (Voorzien is een innovatieve aandrijving met steamjets. Idealiter kan de energie daarvoor vanuit de Slow Mill 'getankt' worden, waardoor er geen uitstoot van verbrandingsgassen zoals kooldioxide (CO2) of stikstofoxide (NOx) ontstaat.) Aangekomen bij de testlocatie worden de luchtkleppen van het anker opengezet zodat het volloopt met water en naar de bodem afzinkt.

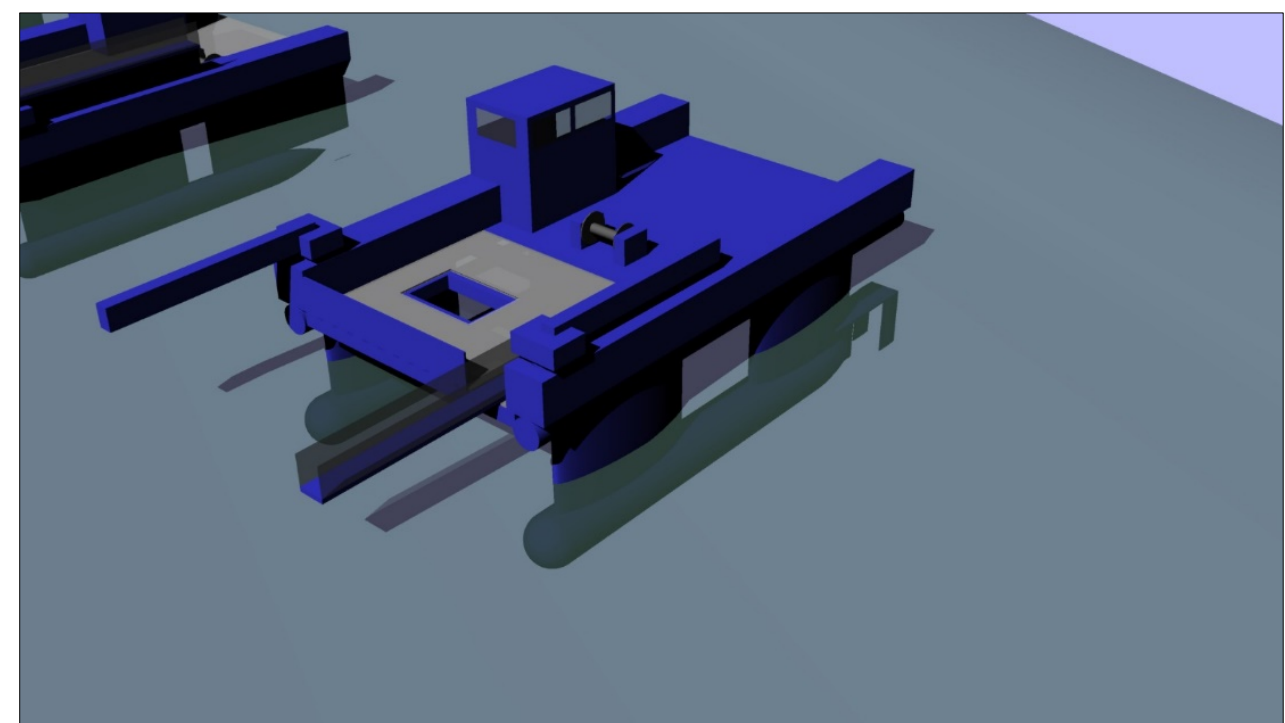

Figuur 7 Schematisch ontwerp installatie-/onderhoudsplatform The Empiric (lengte: ca. $12 \mathrm{~m}$, motorvermogen: 190 pk); bron: Slow Mill Sustainable Power BV

\subsubsection{Aanleggen van de elektriciteitskabel}

In de periode maart-mei 2021 wordt er een elektriciteitskabel aangelegd. Deze heeft een doorsnede van circa $50 \mathrm{~mm}$, en is geschikt voor een spanning van circa $10 \mathrm{kV}$ en een vermogen van circa 2 MVA. Het voorziene tracé verloopt vanaf de Slow Mill-pilotlocatie in zee naar strandpaal 20 (alternatief: 19) ter hoogte van De Koog, en verder door de duinen naar een punt waar de aansluiting met het bestaande elektriciteitsnetwerk kan worden gemaakt. Uit risico-overwegingen komt de kabel in zee op een diepte van 2-3 m onder het zeebodemoppervlak te liggen. Eerst wordt het reeds afgezonken anker omhoog gehaald door middel van het inspuiten van lucht waardoor het gaat drijven. Dan wordt de elektriciteitskabel aan het anker bevestigd. De kabel wordt naar de zeebodem geleid en daar, voordat de kabel wordt ingegraven, op een afstand van max. $5 \mathrm{~m}$ vanaf het anker in een lus op de zeebodem gelegd om speling te creëren voor het herhaaldelijk kunnen ophalen van de installatie. Zo nodig wordt de lus verzwaard. Vanaf het aanlandpunt op het strand wordt de kabel door de duinen getrokken/ingegraven tot aan de eerste mogelijkheid voor de koppeling met het elektriciteitsnet. Er zijn twee aanlandopties (figuur 8). Uitgangspunt bij beide opties is dat de kabel niet door Natura 2000-gebied wordt geleid. Als voor de optie paal 20 wordt gekozen, loopt de kabel langs/onder de Badweg (De Koog) over een afstand van circa $200 \mathrm{~m}$ (parkeerplaats) of $400 \mathrm{~m}$ (bebouwde kom; (figuur 9). Voor het leggen van de kabel in zee wordt een 600 pk diesel schip van $57 \mathrm{~m}$, de offshore support vessel MV RAM, gebruikt; voor het graafwerk aan land een diesel-graafmachine (250 pk). 


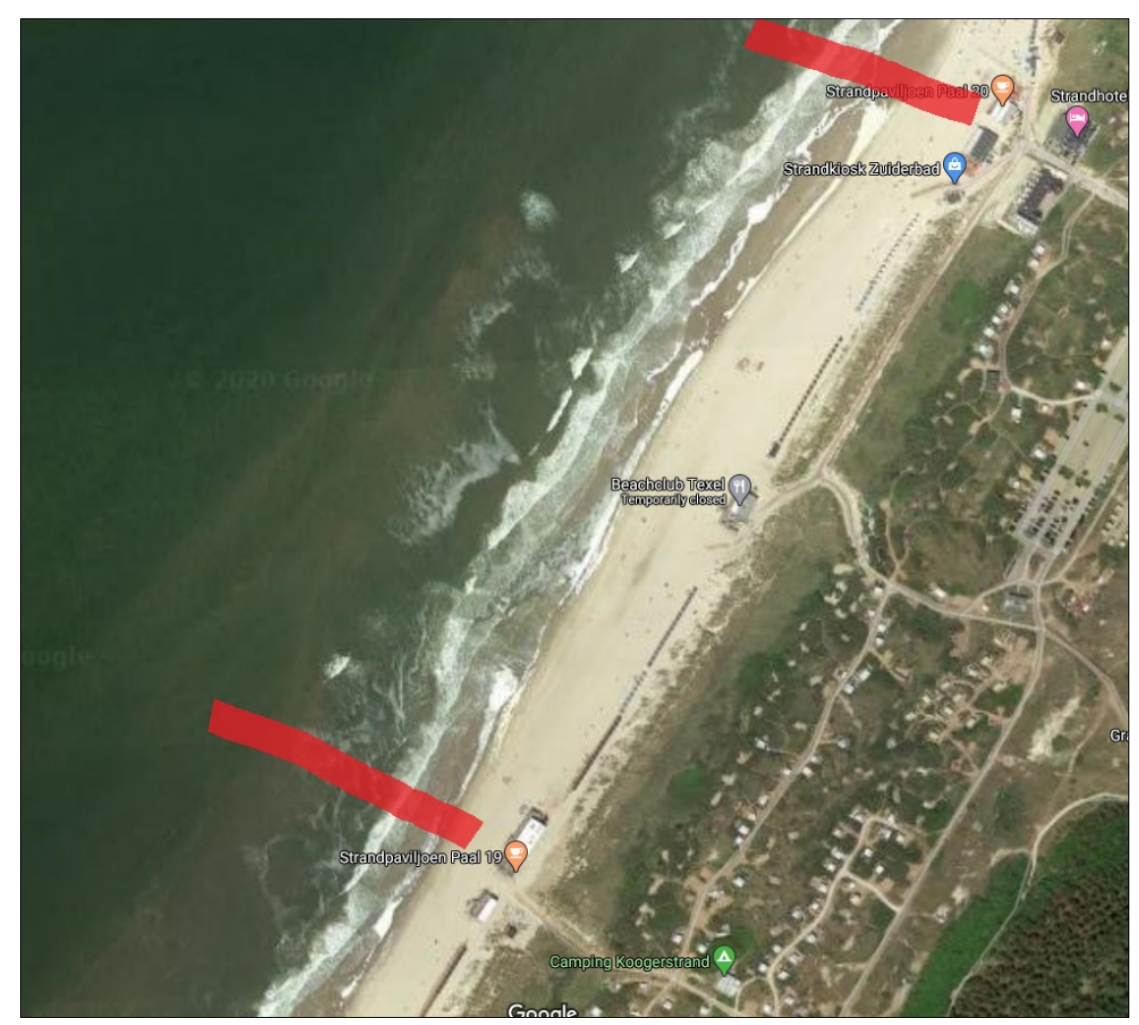

Figuur 8 Locatie aanlanding elektriciteitskabel. Ingetekend (rode lijnen): de aanlanding bij paal 20 en (alternatief) paal 19. Bron (kaart): Google maps.

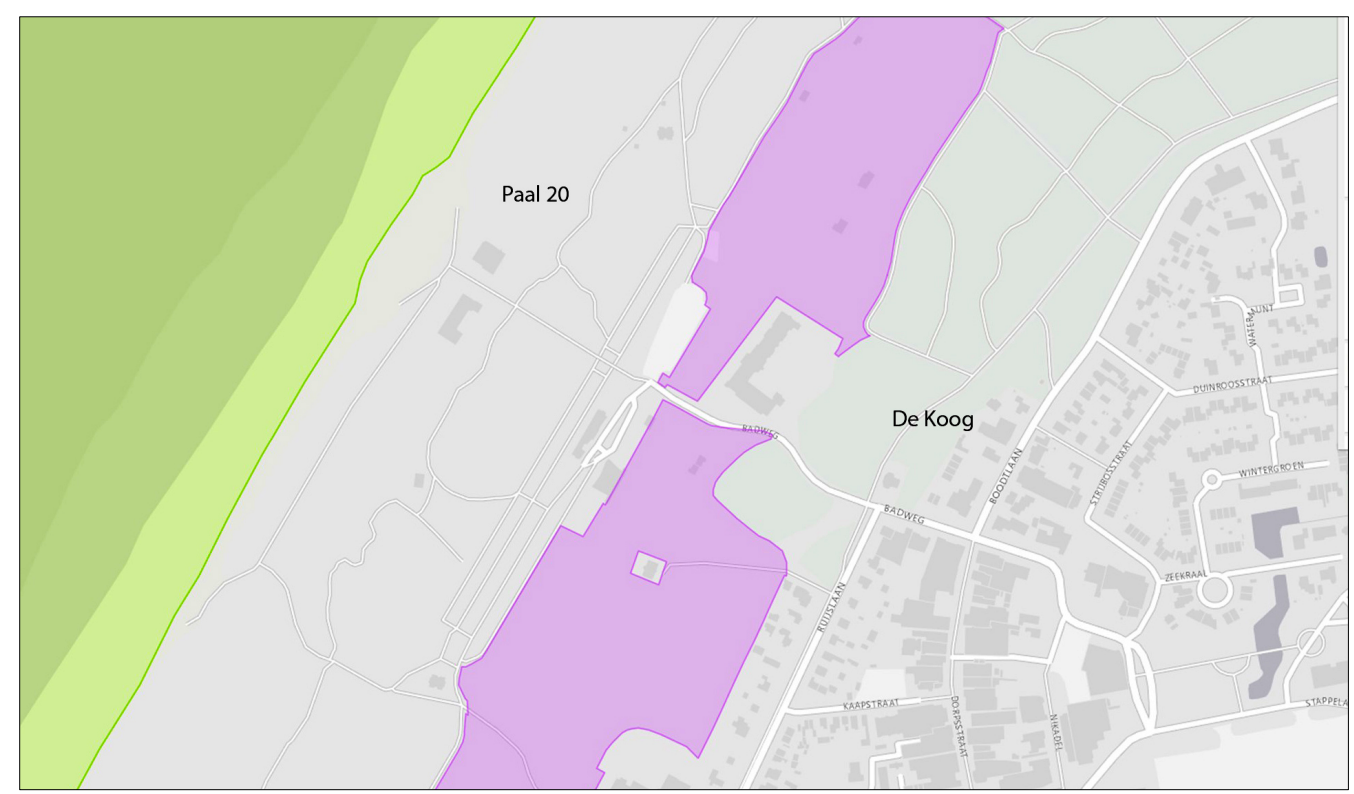

Figuur 9 Situatie bij De Koog. Bij aanlanding bij paal 20 verloopt het kabeltracé vanaf het strand langs/onder de Badweg (geen onderdeel van Natura 2000-gebied Duinen Lage Land Texel; paars). In groen: deel van Natura 2000-gebied Noordzeekustzone. Bron (kaart):

https://geocontent.rvo.nl/Natura2000/Gebiedskaart/index.html?gebiednaam=Noordzeekustzone

\subsubsection{Plaatsen van de Slow Mill-converter}

In mei 2021 wordt de Slow Mill-converter van de Kooyhaven in Den Helder naar de locatie op zee versleept door het gebruik van het installatieplatform The Empiric (figuur 7). De Slow Mill-converter is $20 \mathrm{~m}$ breed en wordt op locatie aan het anker bevestigd. Daarvoor wordt het anker eerst weer, door het inspuiten van lucht waardoor het gaat drijven, van de zeebodem opgehaald. Wanneer de converter geplaatst is, wordt de hele installatie weer naar de zeebodem afgezonken. Het drijvende gedeelte van de Slow Mill-pilotinstallatie wordt getoond in figuur 10. 


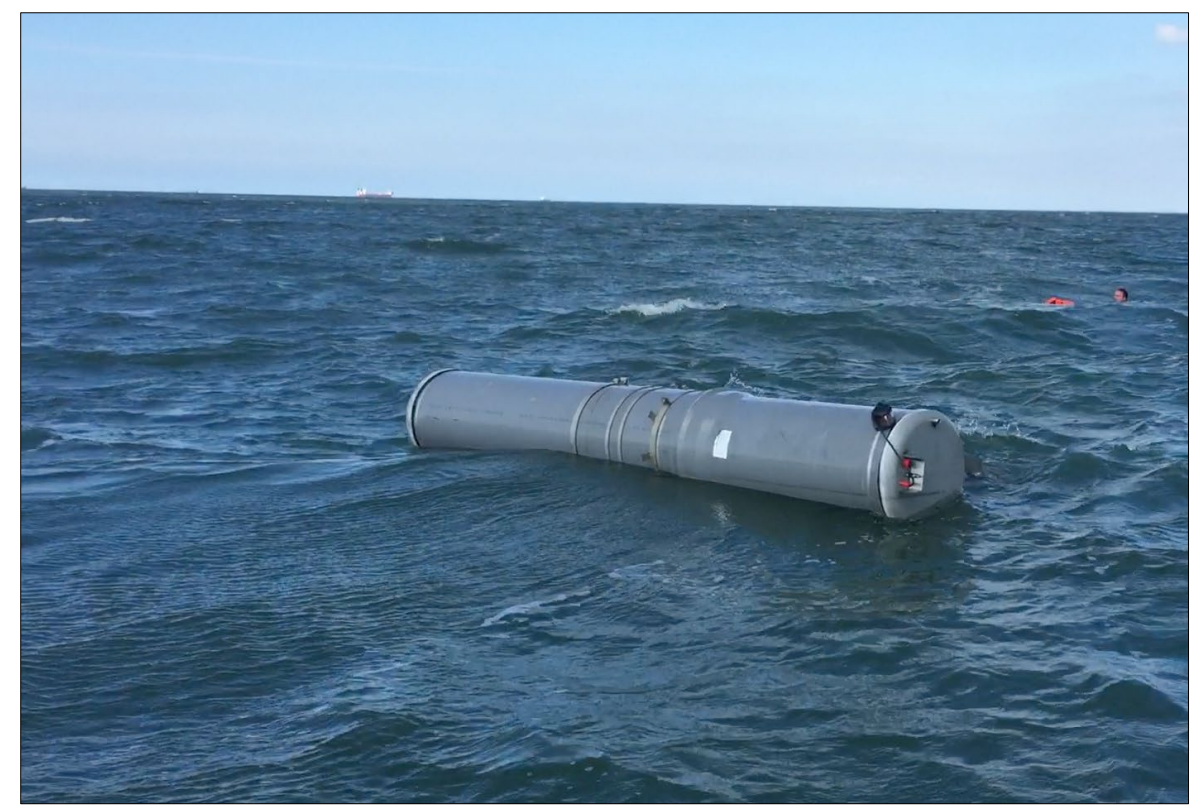

Figuur 10 Slow Mill-pilotinstallatie (bovenwatergedeelte). Bron: Slow Mill Sustainable Power BV

\subsubsection{Inregelen installatie}

Zoals vermeld in tabel 1 zijn in de bouwfase voor diverse montage-, onderhouds- en testwerkzaamheden (kort: het inregelen van de installatie) dertig transporten met het installatie/onderhoudsplatform The Empiric vanuit de Kooyhaven naar de Slow Mill-pilotlocatie voorzien. Ook deze vinden uitsluitend overdag plaats.

\subsubsection{Activiteiten operationele fase}

De operationele fase start op het moment dat de Slow Mill-pilotinstallatie volledig is geplaatst en ingeregeld (mei-juli 2021). De eerste 6-9 maanden (met minimaal één stormseizoen) gelden als testfase. In de operationele fase is er maar één (gecombineerde) activiteit: gepland onderhoud en onderzoek, die gepaard gaat met vaarwerkzaamheden. Tijdens de gehele periode dat de Slow Millpilotinstallatie in werking is, wordt er regelmatig, ongeveer 15 keer per jaar, (preventief en correctief) onderhoud gepleegd en/of onderzoek uitgevoerd. Dit wordt gedaan met het installatie-/onderhoudsplatform The Empiric. Het is mogelijk dat de Slow Mill-converter en/of het anker daarvoor boven water gehaald moeten worden. Het onderhoud zal altijd overdag uitgevoerd worden.

\subsubsection{Ontmantelingsfase}

In de ontmantelingsfase is er maar één activiteit: het opruimen van de gehele Slow Millpilotinstallatie, dus inclusief de kabel (zie tabel 1). Deze activiteit gaat vooral gepaard met vaarwerkzaamheden. Met het installatie-/onderhoudsplatform The Empiric wordt het anker omhoog geblazen en de converter losgekoppeld, waarna beide naar de Kooyhaven in Den Helder worden versleept. De hele operatie duurt één dag en vindt overdag plaats. Ook de kabel wordt compleet verwijderd. Dat zal echter sneller en eenvoudiger gaan dan de aanleg ervan. De kabel hoeft niet te worden uitgegraven maar wordt losgetrokken. Voor het opruimen van de kabel uit de zeebodem wordt ook één dag aangehouden. Het werk wordt uitgevoerd door de service vessel RAM. Het opruimen van de kabel op land (strand/duin) vindt plaats door het opgraven en verwijderen van de kabel met een 250 pkgraafmachine. Het werk duurt één dag en wordt overdag uitgevoerd. 


\subsection{Tijdsplanning}

De planning in de tijd van de verschillende activiteiten in de bouw-, operationele en ontmantelingsfase voor het Slow Mill-pilotproject is schematisch weergegeven in tabel 2. De gehele projectperiode omvat vijf jaar, waarbij de start van het project is voorzien in maart 2021.

Tabel 2 Planning Slow Mill pilot Texel-project

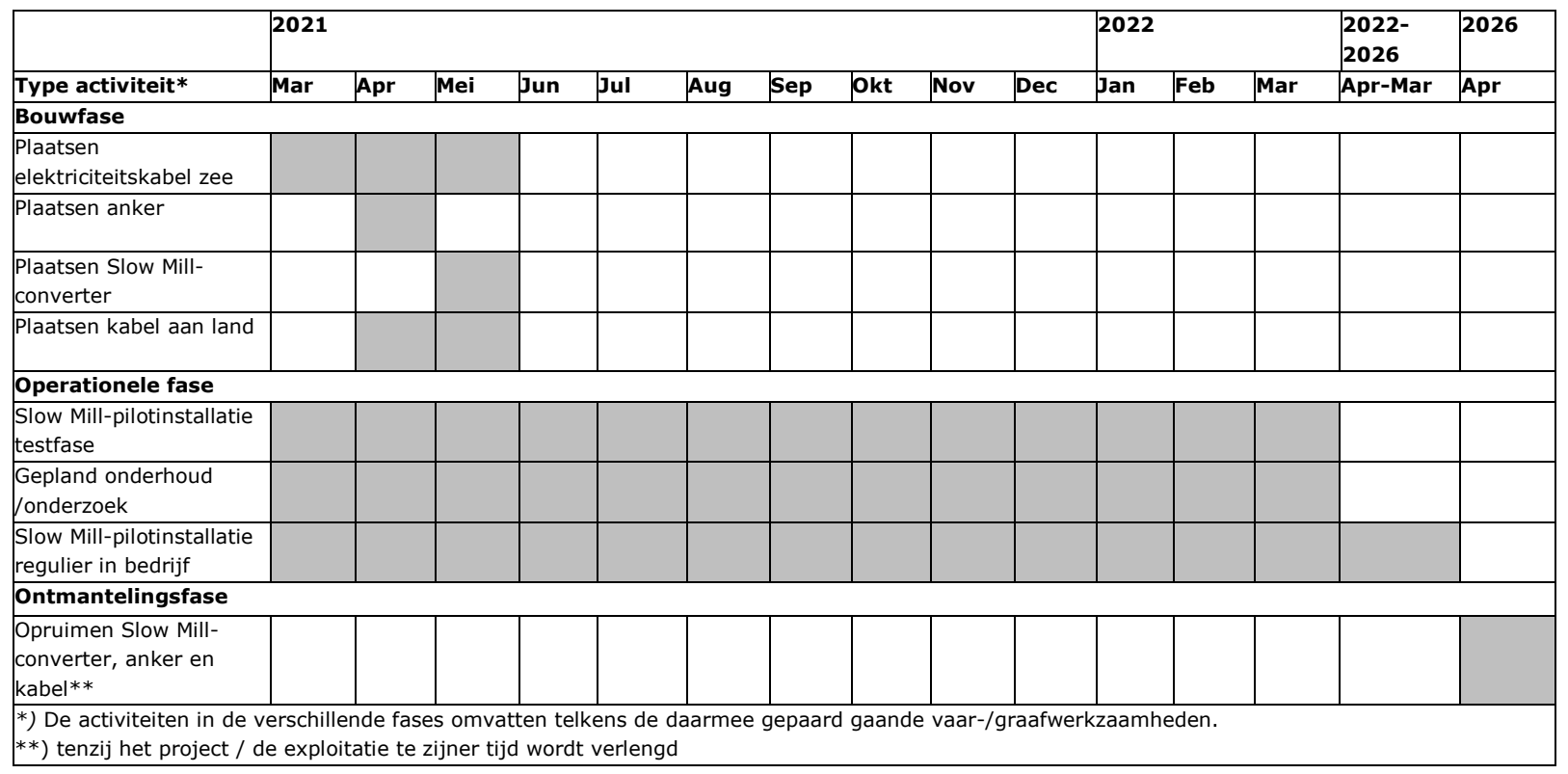




\section{Beschermde natuurwaarden}

In hoofdstuk 2 en 3 is beschreven welke natuurwaarden onder de Wnb worden beschermd. Dit betreft onder meer de bescherming van soorten en habitats onder de HR en de VR. De projectlocatie van de voorgenomen activiteiten is gelegen in het Natura 2000-gebied Noordzeekustzone. Vanwege de mogelijke externe werking vanuit het plangebied op het nabijgelegen Natura 2000-gebied Duinen en Lage Land Texel, wordt daar dus ook aandacht aan besteed. Gezamenlijk vormen deze twee gebieden het studiegebied van deze voortoets. NB De beschermde gebieden wat betreft de stikstofdepositie volgen automatisch uit de AERIUS Calculator zelf.

\subsection{Natura 2000-gebied Noordzeekustzone}

In deze paragraaf worden eerst alle beschermde natuurwaarden van het Natura 2000-gebied Noordzeekustzone aangeduid (figuur 11), waarna de voor het onderhavige project geselecteerde, relevante natuurwaarden worden besproken wat betreft hun globale verspreiding in het gebied en de geldende instandhoudingsdoelstellingen.

\subsubsection{Beschermde naturwarden}

Het Natura 2000-gebied Noordzeekustzone bestaat uit de kustwateren van de Noordzee langs de Noord-Hollandse kust ten noorden van Bergen en langs de hele waddenkust tot aan de Eems. De zeewaartse grens ligt op de doorgaande NAP -20 m-dieptelijn. Langs de Noord-Hollandse vastelandskust ligt de grens aan de landzijde op de laagwaterlijn; het Natura 2000-gebied bestaat daar uit de met water bedekte kustzone. Op de Waddeneilanden behoren de stranden tot aan de duinvoet ook tot de Noordzeekustzone. Op de eilanden ligt de bovengrens op de duinvoet, die daardoor dynamisch is: bij duinaangroei verplaatst de grens zich zeewaarts en bij duinafslag landinwaarts met de duinvoet mee.

De Noordzeekustzone heeft een oppervlakte van circa 144.474 ha en grenst aan de Natura 2000gebieden van de Waddeneilanden en de Waddenzee. De onderlinge samenhang tussen deze gebieden is sterk. Zo spelen de stranden en de vooroevers van de Noordzeekustzone een belangrijke rol als zandleveranciers voor de eilanden. Ook is er veel wisselwerking van sedimentatie- en erosieprocessen tussen de Noordzeekustzone, de eilanden en de Waddenzee met geulen, ondieptes, platen, kwelders en duinen (Ministerie van Infrastructuur en Milieu, 2016a).

Op basis van de HR zijn zes habitattypen, waarvan één met twee subtypen, en zes soorten als Natura 2000-waarde aangewezen. Voor de VR zijn drie soorten als broedvogel en 18 als niet-broedvogel aangewezen; voor één soort betreft de aanwijzing zowel broedvogel als niet-broedvogel. In het voorliggende rapport is uitgegaan van de instandhoudingsdoelstellingen voor habitattypen, habitatsoorten en vogelsoorten zoals beschreven in het concept-aanwijzingsbesluit dat met het wijzigingsbesluit Noordzeekustzone in 2010 definitief is geworden (Ministerie van ELI, 2010). 


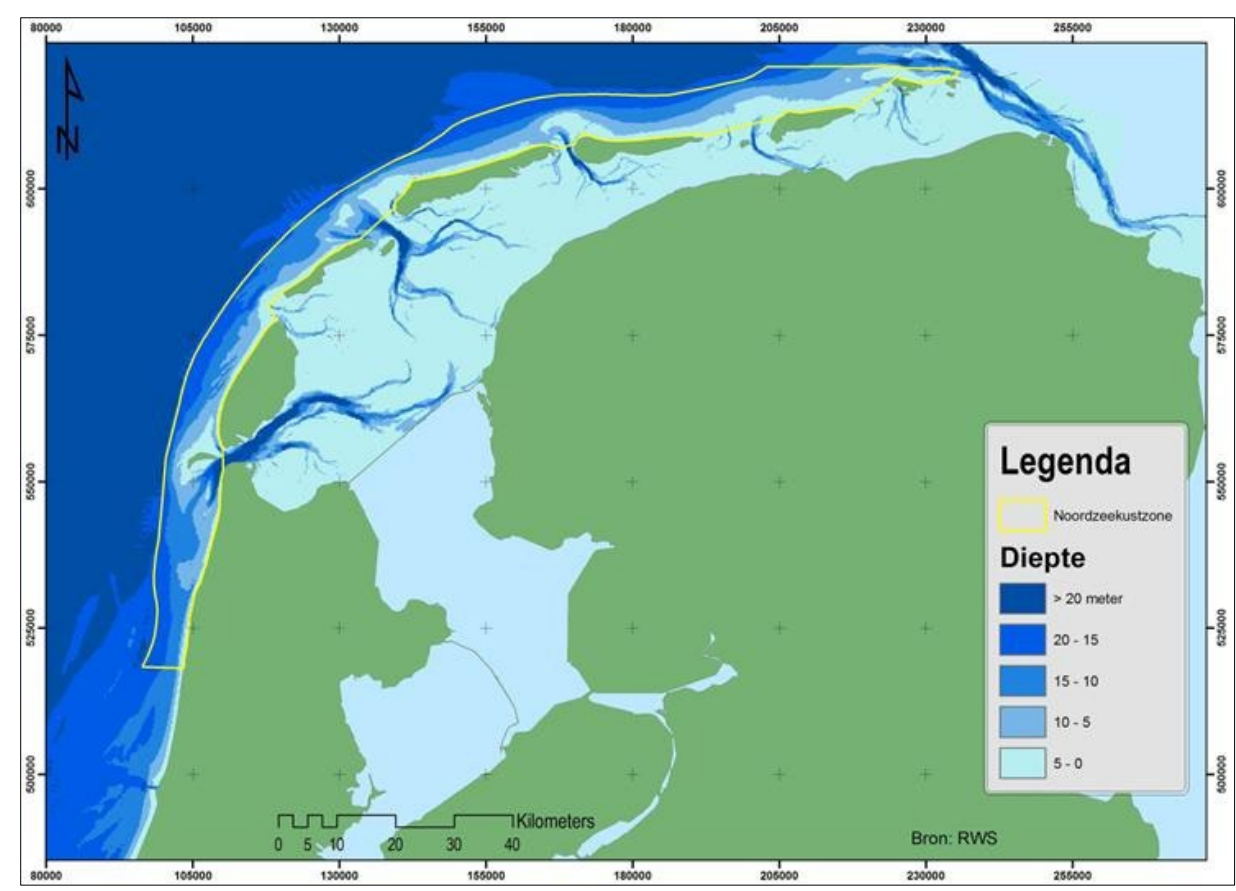

Figuur 11 Ligging Natura 2000-gebied Noordzeekustzone (gele lijn) en omgeving (bron: Ministerie van Infrastructuur en Milieu, 2016a).

In het wijzigingsbesluit Noordzeekustzone (Ministerie van ELI, 2010) zijn de instandhoudingsdoelstellingen van dat gebied beschreven. In bijlage 1 van dit rapport zijn alle instandhoudingsdoelstellingen met hun landelijke staat van instandhouding (SvI), doelstelling oppervlakte/omvang leefgebied, doelstelling kwaliteit/kwaliteit leefgebied en doelstelling populatie/populatie omvang schematisch weergegeven. In het beheerplan 2016-2022 voor het Natura 2000-gebied Noordzeekustzone zijn de doelstellingen uitgewerkt en aangegeven hoe die bereikt moeten worden door middel van maatregelen (Ministerie van Infrastructuur en Milieu, 2016a).

\subsubsection{Relevante beschermde natuurwaarden}

De lijst van habitattypen en HR- en VR-soorten die beschermd worden in Natura 2000-gebied Noordzeekustzone is lang (zie bijlage 1), maar niet alle zijn relevant in relatie tot de beoordeling van de activiteiten van het Slow Mill-pilotproject bij Texel. De habitattypen en soorten die niet in het studiegebied voorkomen, kunnen ook niet worden blootgesteld aan potentiële effecten van de Slow Mill-pilotinstallatie en worden dan ook niet betrokken in de effectbeoordeling voor de voortoets (hoofdstuk 6). Voor de selectie is gebruik gemaakt van informatie uit het beheerplan Noordzeekustzone (Ministerie van Infrastructuur en Milieu, 2016a, b), de onderliggende rapporten van Jak et al. (2014a, 2014b) en het beheerplan Texel (Rijksdienst voor Ondernemend Nederland, 2016). Van de geselecteerde natuurdoelen, dat wil zeggen de habitattypen, habitatsoorten, broedvogels en niet-broedvogels die wel relevant zijn voor deze voortoets, zijn de kenmerken en doelstellingen hieronder beknopt beschreven. Tabel 3 geeft het overzicht.

\subsubsection{Habitattypen}

In de Noordzeekustzone zijn zes verschillende habitattypen (soms met subtypen) voor bescherming aangewezen. In het rapport Natura 2000-doelen in de Noordzeekustzone. Van doelen naar opgaven voor natuurbescherming zijn deze habitattypen uitvoerig beschreven (Jak et al.; 2014a, 2014b). Niet al deze habitattypen komen voor bij de aanlandlocatie van de kabel bij paal 20 (of alternatief paal 19), de Slow Mill-locatie $4 \mathrm{~km}$ uit de kust of in het gebied daartussen. De duin- en kwelderhabitattypen liggen op grote afstand van het plangebied: dichtstbijzijnde locatie is de Slufter op circa $6 \mathrm{~km}$ ten noorden van paal 19/20. Verwacht wordt daarom dat eventuele effecten van de Slow Millpilotinstallatie zich daar niet zullen doen gelden. Habitattype H1110B (permanent overstroomde zandbanken) en H1140B (slik-en zandplaten) komen wel voor in het plangebied, namelijk voor de kust nabij paal 19/20. De habitattypen H1310A (zilte pioniersbegroeiingen; zeekraal), H1310B (zilte pioniersbegroeiingen; zeevetmuur), H1330A (schorren en zilte graslanden; buitendijks), H2110 (embryonale duinen) en H2190B (vochtige duinvalleien; kalkrijk) komen niet voor in het Natura 2000- 
gebied Noordzeekustzone bij Texel (Jak et al.; 2014a, 2014b). De dichtstbijzijnde locatie waar deze habitattypen aanwezig zijn, is de Slufter, vallend onder Natura 2000-gebied Duinen en Lage Land Texel.

De kenmerken en de doelstellingen van de twee habitattypen die relevant zijn voor deze voortoets, worden hieronder nader beschreven.

\section{H1110B: Permanent overstroomde zandbanken}

Het habitattype 'permanent met zeewater van geringe diepte overstroomde zandbanken, subtype Noordzee-kustzone' is aanwezig in vrijwel de gehele Noordzeekustzone. Bijna het gehele plangebied bestaat uit dit habitattype, met uitzondering van een smalle strook van het strand, zoals ook bij paal 19/20 (zie figuur 1) dat bestaat uit habitattype 1140B (zie figuren 2, 3 en 12).

Het habitattype bestaat uit zandbanken in ondiepe delen van de zee die voortdurend onder water staan. Naast de zandbanken maken ook de tussenliggende laagten en geulen er deel van uit. De overstroomde zandbanken hebben een hoge dynamiek van water en bodem. Door inwerking van golven is de stabiliteit van het sediment in de ondiepe delen laag. De Slow Mill-installatie heeft mogelijk een effect op de dynamiek (zie uitleg in paragraaf 5.2.5.). Ten gevolge van bodemberoering (vormen van visserij, kustsuppleties) is het bodemleven in de Noordzeekustzone, ook in de van nature relatief minder dynamische delen, niet stabiel in samenstelling en overwegend opgebouwd uit individurijke, maar soortenarme levensgemeenschappen. De bodemfauna bestaat hier vooral uit soorten met een korte levensduur en/of hoge reproductiesnelheid (zoals borstelwormen en bepaalde schelpdieren). De bodemleefgemeenschap van vis is eveneens instabiel.

Verder uit de kust neemt door toenemende diepte en stabiliteit van de zeebodem de biodiversiteit toe. Hier is een (potentieel) soortenrijke levensgemeenschap aanwezig bestaande uit relatief langlevende soorten. Op de bodem komen vele soorten tweekleppigen, stekelhuidigen en kreeftachtigen voor. Ook is het een belangrijk opgroeigebied voor jonge vis.

Voor habitattype H1110B geldt een behoudsdoelstelling voor de omvang en een verbeterdoelstelling voor de kwaliteit van het gebied. De kwaliteit is als matig ongunstig beoordeeld. Om dit te verbeteren zijn verschillende oplossingsrichtingen beschreven, waaronder verduurzaming van de visserij, onderzoek en monitoring, optimalisatie uitvoering kustverdediging en beheer en onderhoud (Ministerie van Infrastructuur en Milieu, 2016a).

\section{H1140B: Slik- en zandplaten}

Het habitattype 'slik- en zandplaten, subtype Noordzeekustzone' bestaat uit zandplaten en stranden in ondiepe kustgebieden. Zandplaten komen in de zeegaten voor en verplaatsen zich in de richting van het zandtransport. Het habitattype is zeer dynamisch. Door getijdewerking staan de platen afwisselend droog en onder water, en zijn de platen onbegroeid. Veel voorkomende soorten voor dit habitattype zijn de schelpkokerworm, die rond de laagwaterlijn en dieper voorkomt, en de gemshoornworm en zandvlokreeft, die in de getijdezone voorkomen. Deze soorten vormen een voedselbron voor de op de natte stranden foeragerende vogelsoorten zoals drieteenstrandloper, steenloper, bontbekplevier en strandplevier.

In het plangebied bij paal 19/20 komt dit habitattype alleen voor als een strook van strand voor de kust, vanaf de hoogwaterlijn tot zeewaarts het Lowest Astronomical Tide (LAT) dat onder de gemiddelde laagwaterlijn ligt. Zandplaten liggen op afstand, zoals de Razende Bol of de Hors, en komen niet voor in het plangebied.

Voor dit habitattype geldt een behoudsdoelstelling voor zowel omvang als kwaliteit leefgebied, welke waarschijnlijk behaald zal worden met het huidige beleid (Ministerie van Infrastructuur en Milieu, 2016a). Habitattype 1140B komt voor op het strand bij paal 19/20. Het gaat om een strook van hooguit enkele tientallen meters breed. Er zijn niet veel organismen in te vinden, behalve aanspoelsels en wat strandvlooien en (gemshoorn)wormen, die als voedsel voor steltlopers kunnen dienen. 


\subsubsection{Habitatrichtlijnsoorten}

Onder de habitatrichtlijnsoorten van de Noordzeekustzone vallen drie soorten trekvissen en drie soorten zeezoogdieren. Alle soorten komen in het studiegebied voor, en er zijn geen aanwijzingen dat het voorkomen slechts incidenteel is.

\section{Trekvissen}

Er zijn drie soorten trekvissen aangewezen in het studiegebied Noordzeekustzone, namelijk de zeeprik, rivierprik en de fint. Deze drie soorten trekken vanuit zee de rivieren op om er te paaien. De zeeprik trekt in februari-juni de rivier op, de rivierprik in het najaar, en de fint kort voor de paaiperiode in mei-juni. Het grootste gedeelte van hun leven brengen ze door op zee, waarbij wordt vermoed dat kustwateren van groot belang zijn. Het belang van de Noordzeekustzone voor de trek van deze vissen is waarschijnlijk beperkt, maar de kennis daarover is schaars. De trek tussen zoet en zout water vindt vooral plaats in estuaria zoals het Eems-estuarium en de sluizen van de Afsluitdijk. Trekvissen komen echter ook via de zeegaten de Waddenzee binnen, zoals het Marsdiep ten zuiden van Texel en het Eierlandse gat ten noorden van Texel.

De staat van instandhouding van deze soorten is matig ongunstig vanwege de aanwezigheid van barrières om van en naar de rivieren te trekken. Voor alle drie de vissoorten gelden behoudsdoelstellingen voor omvang en kwaliteit leefgebied en uitbreiding van de populatie die waarschijnlijk gehaald gaan worden met het huidige beleid.

\section{Grijze zeehond}

De grijze zeehond is een zeezoogdier en de grootste van de twee algemeen in de Nederlandse wateren voorkomende zeehondensoorten. De dieren maken regelmatig gebruik van droogvallende platen. Meestal verblijven ze echter in de (kust)zee, waar ze foerageren op vis. Voor de voortplanting (november-februari) en verharing (maart-april) is het dier afhankelijk van permanent droogliggende platen, stranden en duinen. In tegenstelling tot die van gewone zeehonden kunnen de jongen van grijze zeehonden na de geboorte niet meteen zwemmen. Als ze in het water terecht komen, zullen ze niet meteen verdrinken maar wegdrijven en mogelijk ergens aanspoelen. Het is daarom belangrijk voor de grijze zeehond om jongen te werpen en te zogen op locaties die niet overstromen. Er zijn geen platen in de directe omgeving van het plangebied die als rust-, zoog-, voortplantingsgebied of voor de verharing van grijze zeehonden zouden kunnen worden gebruikt, en de stranden zijn daarvoor te veel verstoord door met name recreatie. Ongeveer $15 \mathrm{~km}$ ten zuiden van het plangebied ligt de Razende Bol, die wel als voortplantings- en verharingsgebied gebruikt wordt.

Grijze zeehonden komen in de kustzee van het studiegebied voor zoals beschreven in Brasseur et al. (2019). De populatie grijze zeehonden neemt nog steeds toe. Er geldt voor zowel aantallen als omvang en kwaliteit leefgebied een behoudsdoelstelling die op basis van de recente populatieontwikkeling zeker behaald zal worden.

\section{Gewone zeehond}

De gewone zeehond is de meest algemeen voorkomende zeehondensoort van het Nederlandse deel van het Noordzeegebied. De gewone zeehond brengt de meeste tijd door in zee, om te foerageren, te paren, te reizen en te slapen. Hij leeft vooral van aan de bodem gebonden vissen, waaronder veel soorten platvis. Om jongen te werpen (mei-juli), om te verharen (zomer) en om te rusten gebruiken de dieren droogvallende platen, met name in de Waddenzee. In de winterperiode trekken veel gewone zeehonden van de Waddenzee naar de Noordzee waar ze met name in het kustgebied verblijven. Er zijn geen platen in de directe omgeving van het studiegebied aanwezig die als rust-, zoog-, voortplantingsgebied of voor de verharing zouden kunnen worden gebruikt. Ook de stranden in het studiegebied worden niet gebruikt; deze worden te veel verstoord door met name recreatie. De gewone zeehond maakt vooral gebruik van de droogvallende platen in de Waddenzee. De Razende Bol wordt door gewone zeehonden enkel als rustgebied gebruikt. 
Gewone zeehonden komen in de kustzee van het studiegebied voor zoals beschreven in Brasseur et al. (2019). De populatie gewone zeehonden neemt toe en er geldt een behoudsdoelstelling voor zowel aantallen als omvang en kwaliteit van het leefgebied dat op basis van de huidige ontwikkelingen zeker behaald zal worden.

\section{Bruinvis}

De bruinvis is een kleine walvisachtige en het talrijkste zeezoogdier van het Noordzeegebied. Zijn voedsel is gevarieerd en bestaat vooral uit (bodemlevende) vis, zoals wijting, kabeljauw en grondels. De bruinvis is vrij schuw. De dieren leven meestal solitair of in kleine groepen. Bruinvissen worden incidenteel gezien langs de kust nabij het studiegebied (Geelhoed et al., 2020) en komen hier jaarrond voor. De laagste aantallen worden gezien in de periode van mei tot en met september, en de hoogste aantallen in de periode december tot en met maart. Vanaf maart trekken ze weg uit de Noordzeekustzone.

Voor de bruinvis is er een behoudsdoelstelling voor de omvang van het leefgebied en van de populatie, en een verbeteringsdoelstelling voor de kwaliteit van het leefgebied. Voor de kwaliteit geldt dat er meer onderzoek naar de impact van visserijbijvangst en onderwatergeluid gedaan zou moeten worden om op basis daarvan geëigende maatregelen te kunnen nemen.

In het beheerplan voor de Noordzeekustzone is gesteld dat de doelstellingen met het huidige beleid naar verwachting niet behaald zullen worden.

\subsubsection{Vogelrichtlijnsoorten}

In de Noordzeekustzone zijn drie soorten broedvogels en achttien trekvogels ${ }^{3}$ uit de VR aangewezen als beschermde soort. In het rapport Natura 2000-doelen in de Noordzeekustzone. Van doelen naar opgaven voor natuurbescherming (Jak et al., 2014a, 2014b) zijn de doelstellingen, de ecologie en verspreiding van deze vogelsoorten in de Noordzeekustzone uitvoerig beschreven. Hieronder volgt een beknopte weergave.

\section{Broedvogels}

De drie broedvogelsoorten bontbekplevier, strandplevier en dwergstern broeden op de groene stranden van de Noordzeekustzone. De broedgebieden bevinden zich in de pionierzones waar de habitattypen $\mathrm{H} 2110$ (embryonale duinen), $\mathrm{H} 1310$ (zilte pioniersbegroeiingen) en $\mathrm{H} 1330$ (schorren en zilte graslanden) deel van uitmaken. De broedvogels zijn tevens onderdeel van de kernopgave voor de Noordzeekustzone als voortplantingshabitat en kennen een zgn. sense of urgency voor het beheer. De consequentie hiervan is dat in de komende beheerplanperiode gezorgd moet worden voor afdoende maatregelen voor het behoud van ongestoorde rustplaatsen en voortplantingshabitat voor deze broedvogels.

Op Texel broedden een tiental jaren geleden enkele paren bontbekplevieren op relatief rustige delen van het strand; met name tussen strandpaal 8 en 9, bij paal 12 en nabij de Dam bij de vuurtoren (Krol, 2010) en ook in de Slufter die slechts voor een beperkt deel, namelijk onder de hoogwaterlijn, tot de Noordzeekustzone behoort. Vanaf 2003 is dit aantal gedaald (van vier paar tot nul in 2006). Voor zowel de bontbekplevier als de strandplevier wordt het aantal broedparen in de periode 20092013 geschat op nul, maar bontbekplevieren komen soms nog wel tot broeden op Texel. In het aanwijzings-/wijzigingsbesluit wordt gesteld dat de Noordzeekustzone onvoldoende draagkracht heeft voor een zelfstandige sleutelpopulatie van de dwergstern, maar wel bijdraagt aan de draagkracht in de regio westelijk waddengebied ten behoeve van een regionale sleutelpopulatie, onder meer op de Razende Bol en op Texel (de Hors). Deze informatie duidt erop dat het studiegebied, waarin geen groene strand-habitattypen voorkomen, niet van betekenis is voor de drie broedvogelsoorten van de Noordzeekustzone.

\footnotetext{
${ }^{3}$ Een van de soorten, namelijk de bontbekplevier, is zowel broed- als trekvogel.
} 
De bontbekplevier, strandplevier en dwergstern zijn behalve voor de Noordzeekustzone ook aangewezen voor het Natura 2000-gebied Waddenzee. Daarnaast zijn de dwergstern en de bontbekplevier aangewezen voor het Natura 2000-gebied Duinen en Lage Land Texel. De bontbekplevier broedt op Texel soms en dan met name op de Hors en in de Slufter. De strandplevier broedt op Texel alleen incidenteel op de Schorren, de Hors of op de noordpunt van Texel (bij de vuurtoren). Op de potentiële broedgebieden op de stranden en de Hors, komt de strandplevier niet voor, waarschijnlijk omdat er te veel verstoring plaatsvindt. Op de Noordzeestranden van de overige Waddeneilanden neemt het aantal broedparen snel af. De bontbekplevier heeft een behoudsdoelstelling voor zowel omvang als kwaliteit van het leefgebied. De strandplevier heeft een verbeterdoelstelling voor omvang en kwaliteit van het leefgebied. Die moet gerealiseerd worden door het creëren van rust in de nabijheid van (potentiële) broedlocaties. Daarnaast moet bij het uitvoeren van zandsuppleties rekening worden gehouden met de aanwezigheid van broedlocaties. De dwergstern is naaste de Natura 2000-gebieden Noordzeekustzone en Waddenzee ook aangewezen voor Duinen en Lage Land Texel. Op de Hors broedt de dwergstern sinds 1988. Aan de Sluftermonding broedden in 2020 circa zeventig paren dwergsterns, tot ze door een stormvloed werden weggespoeld. De dwergstern heeft voor alle drie Natura 2000-gebieden een uitbreidings- en verbeterdoelstelling. Die moeten gerealiseerd worden door het garanderen van rust op de bestaande broedlocatie (Razende Bol, Steenplaat) en op potentiële broedlocaties (Beheerplan Texel; Rijksdienst voor Ondernemend Nederland, 2016).

\section{Verspreiding:}

Voor de op het strand broedende vogelsoorten van het Natura 2000-gebied Noordzeekustzone is van belang na te gaan of het strand bij paal 19/20 van betekenis is.

- De bontbekplevier en strandplevier zijn in de afgelopen jaren in het broedseizoen niet aangetroffen in dit gebied (Beheerplan Texel; Rijksdienst voor Ondernemend Nederland, 2016; SOVON en CBS, 2005). Met uitzondering van de kust van Schiermonnikoog werden broedgevallen van de bontbekplevier en strandplevier op de stranden van de Waddeneilanden nauwelijks gemeld (Jak et al., 2014a, 2014b). Recent zijn er echter 23/24 meldingen geweest van broedparen van de bontbekplevier op Texel. Zij bevonden zich op de brede stranden langs de westkust, de parkeerterreinen van de strandslagen als ook aan de oostkust (Vogelwerkgroep Texel, 2020). Omdat er veel recreatie is in het studiegebied en het strand niet al te breed, is de kans op aanwezigheid van broedparen van deze steltlopersoorten hier echter minimaal.

- De dichtstbijzijnde broedplekken voor dwergsterns liggen in de Slufter, op de Hors, de Razende Bol en de Steenplaat, respectievelijk 5, 10, 15 en $15 \mathrm{~km}$ van het plangebied. De foerageerrange van broedvogels is doorgaans slechts circa $2 \mathrm{~km}$ rond het nest (Beijersbergen, 2016); dus broedvogels zullen niet in het plangebied komen foerageren. Mede door de grote hoeveelheid recreatie in het gebied is de kans op broedparen in het studiegebied minimaal, en zijn dwergsterns als broedvogel hier niet relevant; zie ook beheerplan voor Natura 2000-gebied Noordzeekustzone (Ministerie van Infrastructuur en Milieu, 2016a), Beheerplan Texel (Rijksdienst voor Ondernemend Nederland, 2016), en vogelwaarnemingen van de vogelwerkgroep Texel (www.vwgtexel.nl/waarnemingen/).

\section{Niet-broedvogels}

De Noordzeekustzone is van betekenis als rui- en/of overwinteringsgebied en rustplaats voor een groot aantal niet-broedvogels. Het gaat om vogels die voornamelijk op het open water leven en foerageren op vis (roodkeelduiker, parelduiker, aalscholver, dwergmeeuw) of tweekleppigen (eider, zwarte zee-eend, topper). Daarnaast gaat het om steltlopers die hun voedsel zoeken op de stranden, platen, kwelders en duinen van de Noordzeekustzone. Deze bodemdieren-etende vogels zijn steenloper, bergeend, bontbekplevier en drieteenstrandloper. Andere soorten gebruiken de stranden, platen, kwelders en duinen vooral om te rusten (bonte strandloper, rosse grutto en zilverplevier). Kluut en wulp komen niet voor op de standen van de Noordzeekustzone. Voor de ecologische randvoorwaarden, de ruimtelijke en temporele uitwerking en de doelrealisatie zie Jak et al. (2014b).

Voor alle soorten niet-broedvogels (waaronder trekvogels) geldt behoud van het leefgebied als doelstelling. Voor de meeste soorten zal dit doel zonder aanvullende maatregelen gehaald worden 
(drieteenstrandloper, bonte strandloper) of waarschijnlijk gehaald worden (aalscholver, bergeend, bontbekplevier, scholekster, kluut, zilverplevier, rosse grutto, wulp, steenloper) (Ministerie van Infrastructuur en Milieu, 2016a). Voor de topper, eider en dwergmeeuw is vanwege gebrek aan kennis onduidelijk of de behoudsdoelstelling gehaald zal worden. Voor de zwarte zee-eend is gesteld dat de doelstelling waarschijnlijk niet bereikt zal worden (Ministerie van Infrastructuur en Milieu, 2016a).Voor een aantal vogelsoorten van het open water (roodkeelduiker, topper, eider en zwarte zee-eend), geldt als kernopgave behoud van de kwaliteit van het zee-ecosysteem met permanent overstroomde zandbanken (H1110B) als habitattype.

Verspreiding:

Er zijn 18 niet-broedvogels met een instandhoudingsdoelstelling voor het Natura 2000-gebied Noordzeekustzone. Al deze soorten kunnen voorkomen in het studiegebied. De Noordzeekustzone is een groot gebied, waarvan het studiegebied slechts een gering deel uitmaakt. De verspreiding van de beschermde vogelsoorten wordt o.a. gemonitord door SOVON en de verspreidingskaarten laten zien dat op Texel de meeste soorten grotere dichtheden aan de Waddenzee-zijde hebben in vergelijking met de Noordzeekustzone-zijde (Jak et al., 2014b; Beheerplan Noordzeekustzone, Ministerie van Infrastructuur en Milieu, 2016a; Beheerplan Texel, Rijksdienst voor Ondernemend Nederland, 2016; Wiersma \& Smit, 2009). De drieteenstrandloper is hierbij een uitzondering omdat deze een behoorlijk gelijkmatige dichtheid heeft over het hele Texelse Noordzeekustzone-strand van noord tot zuid, inclusief het studiegebied. Voor de meest actuele gegevens over de verspreiding en trends in aantallen van vogelsoorten wordt verwezen naar www.sovon.nl.

- Voor twaalf niet-broedvogels van de Noordzeekustzone (bergeend, topper, scholekster, kluut, bontbekplevier, zilverplevier, kanoet, drieteenstrandloper, bonte strandloper, rosse grutto, wulp, steenloper) kan op basis van het voorgaande worden vastgesteld dat deze soorten verder buiten beschouwing mogen blijven omdat hun aantallen in het studiegebied gemiddeld genomen te klein zijn om betekenis te hebben.

- De overige zes niet-broedvogelsoorten zijn wel relevant.De aalscholver komt als broedvogel voor op Texel, met twee grote kolonies (de Geul en de Muy) en ze foerageren massaal voor de kust van De Koog (onderdeel studiegebied). Naast de aalscholver, komen ook de roodkeelduiker, eidereend, zwarte zee-eend en dwergmeeuw op open water voor, en veelvuldig ook in het studiegebied. De parelduiker is een schaarse doortrekker in voor- en najaar in de Noordzeekustzone en dus ook in het studiegebied.

Alle voor de voortoets relevante soorten staan overzichtelijk vermeld in tabel 3. 
Tabel 3 Overzicht van habitattypen en -soorten van het Natura 2000-gebied Noordzeekustzone en hun instandhoudingsdoelen. De typen en soorten die in deze voortoets verder buiten beschouwing blijven omdat ze er niet voorkomen of alleen in zeer kleine aantallen, zijn grijs weergegeven.

\begin{tabular}{|c|c|c|c|c|c|}
\hline $\begin{array}{l}\text { Instandhoudingsdoelen } \\
\text { Noordzeekustzone }\end{array}$ & 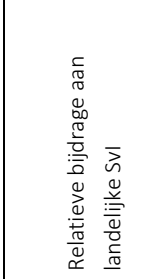 & 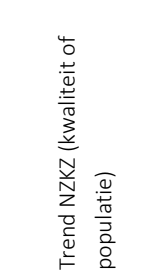 & 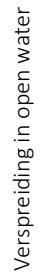 & 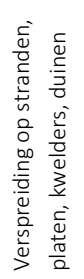 & 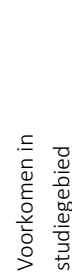 \\
\hline \multicolumn{6}{|l|}{ Habitattypen } \\
\hline H1110B - Permanent overstroomde zandbanken & ++ & Onduidelijk & $\mathrm{x}$ & & $\mathrm{x}$ \\
\hline H1140B - Slik- en zandplaten & +++ & Stabiel & & $\mathrm{x}$ & $\mathrm{x}$ \\
\hline H1310A - Zilte pionierbegroeiingen (zeekraal) & + & Stabiel & & $x$ & \\
\hline H1310B - Zilte pionierbegroeiingen (zeevetmuur) & +++ & Stabiel & & $x$ & \\
\hline H1330A - Schorren en zilte graslanden (buitendijks) & Gering & Stabiel & & $x$ & \\
\hline H2110 - Embryonale duinen & +++ & Stabiel & & $\mathrm{x}$ & \\
\hline H2190B - Vochtige duinvalleien (kalkrijk) & + & Onduidelijk & & $x$ & \\
\hline \multicolumn{6}{|l|}{ Habitatsoorten } \\
\hline H1095 - Zeeprik & + & Stabiel & $\mathrm{x}$ & & $\mathrm{v}$ \\
\hline H1099 - Rivierprik & + & Stabiel & $\mathrm{x}$ & & $\mathrm{v}$ \\
\hline H1103 - Fint & + & Stabiel & $\mathrm{x}$ & & $\mathrm{v}$ \\
\hline H1351 - Bruinvis & + & Toenemend & $\mathrm{x}$ & & $\mathrm{x}$ \\
\hline H1364 - Grijze zeehond & + & Toenemend & $\mathrm{x}$ & $\mathrm{x}$ & $\mathrm{x}$ \\
\hline H1365 - Gewone zeehond & + & Toenemend & $\mathrm{x}$ & $\mathrm{x}$ & $\mathrm{x}$ \\
\hline \multicolumn{6}{|l|}{ Broedvogelsoorten } \\
\hline A137-Bontbekplevier & + & Onduidelijk & & $\mathrm{b}$ & \\
\hline A138 - Strandplevier & + & Afnemend & & $\mathrm{b}$ & \\
\hline A195 - Dwergstern & Gering & Afnemend & & $\mathrm{b}$ & \\
\hline \multicolumn{6}{|l|}{ Niet-broedvogelsoorten } \\
\hline A001 - Roodkeelduiker & ++ & Onduidelijk & $x$ & & $\mathrm{x}$ \\
\hline A002 - Parelduiker & ++ & Onduidelijk & $x$ & & $x$ \\
\hline A017 - Aalscholver & + & Onduidelijk & $x$ & & $x$ \\
\hline A048 - Bergeend & Gering & Afnemend & & $x$ & $\mathrm{v}$ \\
\hline A062-Topper & + & Afnemend & $\mathrm{x}$ & & $\mathrm{v}$ \\
\hline A063 - Eider & ++ & Afnemend & $x$ & & $x$ \\
\hline A065 - Zwarte zee-eend & +++ & Afnemend & $\mathrm{x}$ & & $\mathrm{x}$ \\
\hline A130 - Scholekster & Gering & Onduidelijk & & $x$ & $\mathrm{v}$ \\
\hline A132-Kluut & Gering & Onduidelijk & & $x$ & $\mathrm{v}$ \\
\hline A137 - Bontbekplevier & Gering & Onduidelijk & & $x$ & $\mathrm{v}$ \\
\hline A141 - Zilverplevier & + & Onduidelijk & & $x$ & $\mathrm{v}$ \\
\hline A143 - Kanoet & Gering & Onduidelijk & & $x$ & $\mathrm{v}$ \\
\hline A144 - Drieteenstrandloper & ++ & Toenemend & & $x$ & $\mathrm{v}$ \\
\hline A149 - Bonte strandloper & + & Onduidelijk & & $\mathrm{x}$ & $\mathrm{v}$ \\
\hline A157 - Rosse grutto & + & Toenemend & & $x$ & $\mathrm{v}$ \\
\hline A160 - Wulp & Gering & Stabiel & & $x$ & $\mathrm{v}$ \\
\hline A169 - Steenloper & Gering & Onduidelijk & & $x$ & $\mathrm{v}$ \\
\hline A177 - Dwergmeeuw & ++ & Fluctuerend & $\mathrm{x}$ & & $x$ \\
\hline
\end{tabular}

Legenda:

$\mathrm{b}=$ broedvogel

Relevante bijdrage van het gebied aan de landelijke Staat van Instandhouding (SvI)

\begin{tabular}{|c|c|}
\hline Gering & $<2 \%$ \\
\hline+ & $2-15 \%$ \\
\hline++ & $15 \%-50 \%$ \\
\hline+++ & $>50 \%$ \\
\hline
\end{tabular}

Voorkomen in studiegebied

\begin{tabular}{|c|l|}
\hline & Komt niet voor \\
\hline $\mathrm{v}$ & komt relatief weinig voor \\
\hline $\mathrm{x}$ & komt regelmatig en/of soms in grote aantallen voor \\
\hline
\end{tabular}




\subsection{Natura 2000-gebied Duinen en Lage Land Texel}

Het Natura 2000-gebied Duinen en Lage Land Texel beslaat een oppervlakte van 4.615 ha en wordt landschappelijk gekenmerkt door een uitgestrekt duingebied, met daarbinnen een stelsel van geulen en slenken (de Slufter) met o.a. een karakteristieke kweldervegetatie. Het noordelijk en het zuidelijk gedeelte behoorden oorspronkelijk tot twee verschillende eilanden: het oorspronkelijke Texel en Eierland. Ten westen van de stuifdijk die sinds 1629 de voormalige eilanden verbindt, ligt een oude strandvlakte met een reeks grote valleien. Het deel ten noorden van de Slufter (Eierlandse duinen) omvat oude duinen met graslanden en heiden; het zuidelijke deel is meer gevarieerd met zowel oude als jonge duingebieden. In het gebied is een grote diversiteit aan duinvalleien aanwezig, die verschillen in de mate van infiltratie dan wel kwel. Ook bevinden zich er enkele relatief grote duinplassen zoals de Horsmeertjes, de Muy en de Geul. In de Westerduinen zijn naald- en loofbossen aanwezig. Aan de zuidkant ligt een grote zandplaat, de Hors, die grotendeels deel uitmaakt van het Natura 2000-gebied Waddenzee (Ministerie van LNV, 2008).

\subsubsection{Beschermde natuurwaarden}

In het Aanwijzingsbesluit Duinen en Lage Land Texel ((Ministerie van LNV, 2008) zijn de instandhoudingsdoelstellingen beschreven. In bijlage 2 van dit rapport zijn alle instandhoudingsdoelstellingen met hun landelijke staat van instandhouding (SvI), doelstelling oppervlakte/omvang leefgebied, doelstelling kwaliteit/kwaliteit leefgebied en doelstelling populatie/populatie omvang schematisch weergegeven.

\subsubsection{Relevante beschermde natuurwaarden}

De activiteiten voor het Slow Mill-pilotproject vinden niet plaats binnen de grenzen van het Natura 2000-gebied Duinen en Lage Land Texel. Echter via externe werking kunnen potentieel negatieve effecten van de aanleg van de kabel op het strand bij paal 20 (alternatief paal 19; denk aan verstoringsfactoren als geluid en stikstofemissie) op de habitattypen en -soorten in een relatief klein deel van dat gebied niet op voorhand uitgesloten worden.

Een effect van de stikstofdepositie door graaf- en vaarwerkzaamheden in zee en op het strand (zie hoofdstuk 7) op de vegetatie in het aangrenzende Natura 2000-gebied Duinen en Lage Land Texel is niet uit te sluiten.

$\mathrm{Er}$ is nog een ander type externe werking dat relevant is om hier te beschouwen. Er zijn namelijk drie vogelsoorten die broedvogel zijn op Texel en in redelijk grote getalen foerageren in het studiegebied, nl. de Noordzeekustzone. Het gaat om de kleine mantelmeeuw, grote stern en aalscholver. Voor de kleine mantelmeeuw geldt een instandhoudingsdoelstelling als broedvogel in Natura 2000-gebied Duinen en Lage Land Texel; voor de beide andere soorten niet. De grote stern heeft wel een instandhoudingsdoelstelling als broedvogel in Natura 2000-gebied Waddenzee. De Noordzeekustzone behoort tot het reguliere foerageergebied van de kleine mantelmeeuw van Texel al kunnen de aantallen sterk fluctueren, wat overigens eigen is aan meeuwen. De foerageervluchten van grote sterns kunnen zich over een aanzienlijk areaal uitstrekken. Uit onderzoek met GPS-trackers is bekend dat op Texel broedende grote sterns behalve in de Waddenzee en de zeegaten, langs de hele Noordzee-kustlijn van Texel (en noordelijker gelegen Waddeneilanden) foerageren (Baptist en Leopold 2018). Beide soorten zijn dus relevant voor deze voortoets.

\subsection{Andere beschermde soorten}

In hoofdstuk 2 is beschreven dat er verschillende soorten vissen, vogels, vleermuizen en zeezoogdieren op de lijsten van beschermde soorten staan (bijlage IV van de habitatrichtlijn, bijlage II van Bern en/of bijlage I van Bonn). Slechts een deel van die soorten betreft mariene soorten die relevant kunnen zijn voor de effectbeoordeling in onderhavige voortoets omdat ze op zee kunnen worden aangetroffen. Dan gaat het om een aantal vissen, vleermuizen, en zeezoogdieren (zie bijlage 5). Enkele van deze soorten vissen en zeezoogdieren hebben een instandhoudingsdoelstelling voor 
Natura 2000-gebied Noordzeekustzone en zijn daarom al eerder aan de orde gekomen. Daarom worden ze hier ook alleen beknopt als groepen nog een keer besproken.

\subsubsection{Vissen}

Alle van nature in Nederland voorkomende soorten vissen worden beschermd, met uitzondering van de soorten waarop de Visserijwet 1963 van toepassing is. Een groot aantal zoutwatervissen valt dus formeel onder de bijlage IV van de HR, bijlage II van Bern en/of bijlage I van Bonn (want ze zijn inheems maar ze vallen niet onder de Visserijwet), maar dit is niet als zodanig bekend gemaakt zodat deze wettelijke status niet tot nauwelijks algemeen bekend is (van Keeken et al., 2010). Er zijn zeven vissoorten die op één of meerdere van de bijlage II, III, IV van de Habitatrichtlijn staan (elft, fint, houting, rivierprik, steur, zalm, zeeprik) en bovendien regelmatig als gast of voortplanter op het Nederlands Continentaal Plat (NCP) zijn aangetroffen (zie bijlage 5).

\subsubsection{Vogels}

Alle van nature in Nederland in het wild levende vogels, zoals bedoeld in artikel 1 van de VR worden beschermd. Dit betreft een zeer groot aantal soorten. De Noordzeekustzone is door de hoge voedselrijkdom van bijzonder belang voor veel soorten zeevogels.

\subsubsection{Zoogdieren}

Zeezoogdieren op het NCP zijn verschillende soorten zeehonden, walvissen en dolfijnen. De grijze zeehond en gewone zeehond stonden al vermeld in respectievelijk tabel 2 en 3 van de (oude) Floraen Faunawet en dat is voor beide soorten bijlage III en V van de HR. Alle walvisachtigen behoren tot de meest strikt beschermde categorie van 'tabel 3' en dat is bijlage IV van de HR (zie bijlage 5 van deze voortoets). Van de zeezoogdiersoorten zijn alleen bruinvis, gewone zeehond en grijze zeehond relevant voor de Noordzeekustzone. Ook vleermuizen vallen onder die strikte bescherming van de Wnb-wet. In totaal zijn er twintig soorten vleermuizen aangemerkt. Er zijn echter geen specifieke mariene soorten vleermuizen op het NCP, maar van vijf soorten (zie bijlage 5) is bekend dat ze wel boven zee voorkomen (Boshamer \& Bekker, 2008; Jonge Poerink et al., 2013; Lagerveld et al., 2019).

In deze voortoets is de effectbeschrijving (hoofdstuk 5) gericht op de soortgroepen in het algemeen (o.a. vissen, vogels, zeezoogdieren); de toepassing op relevante soorten binnen die soortgroepen vindt plaats in hoofdstuk 6 . De relevante mariene soorten, vanuit de soortenbescherming van de Wnb en vanuit hun status als regelmatig waargenomen op het NCP (zie bijlage 5) en voorkomend in het studiegebied, zijn ook soorten met een instandhoudingsdoelstelling voor het Natura 2000-gebied Noordzeekustzone. De extra aandachtsoorten zijn elft, houting, steur en zalm en vijf soorten vleermuizen. 


\section{Effectbeschrijving}

Voor een globale inschatting van de mogelijke negatieve effecten van de Slow Mill-pilotinstallatie op de relevante beschermde natuurwaarden in het studiegebied is het noodzakelijk te weten door welk type verstoringsfactoren de Slow Mill-pilotinstallatie potentiële effecten kan hebben op groepen van organismen en hoe relevant die worden geacht. Dat wordt in dit hoofdstuk beschreven. De toepassing van de vergaarde kennis op individuele soorten binnen die soortgroepen, om vast te stellen of significante effecten door de Slow Mill-installatie bij voorbaat en met zekerheid uit te sluiten zijn, wordt pas in hoofdstuk 6 gedaan.

Als eerste stap voor deze analyse worden de verstoringsfactoren (drukfactoren) geïnventariseerd die op kunnen treden door de Slow Mill-pilotinstallatie zelf en door de activiteiten die gepaard gaan met het installeren, onderhouden en ontmantelen ervan. Dit wordt gedaan in paragraaf 5.1. Als tweede stap is een literatuuronderzoek uitgevoerd waarbij informatie over de potentiële verstoringsfactoren van WECs in het algemeen is verzameld. Het resultaat daarvan en de relevantie voor de Slow Mill-pilot worden gepresenteerd in paragraaf 5.2. Deze paragraaf sluit af met een overzicht van de selectie van factoren die relevant zijn voor de Slow Mill-pilotinstallatie.

\subsection{Mogelijke verstoringsfactoren van de activiteiten}

In tabel 4 zijn de verstoringsfactoren toegekend aan de drie fasen (bouwfase, operationele fase en ontmantelingsfase) van de voorgenomen activiteiten die eerder zijn beschreven in tabel 1. 
Tabel 4 Kruistabel waarbij de projectactiviteiten van de Slow Mill-pilotinstallatie zijn uitgezet tegenover de geïdentificeerde verstoringsfactoren

\begin{tabular}{|c|c|c|c|c|c|c|c|c|c|c|c|}
\hline Activiteiten & 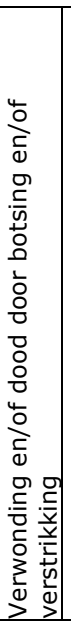 & 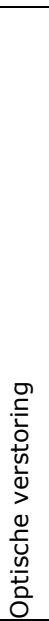 & 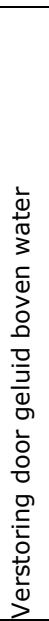 & 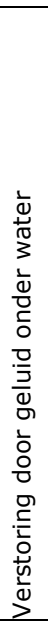 & 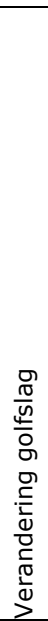 & 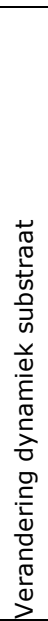 & 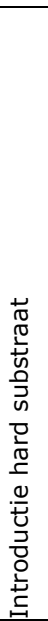 & 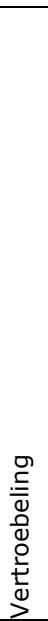 & 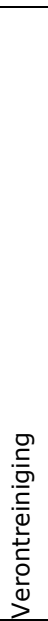 & 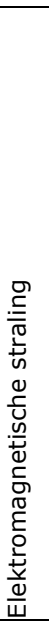 & 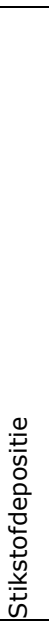 \\
\hline \multicolumn{12}{|l|}{ Bouwfase } \\
\hline Plaatsen anker & & $x$ & $\mathrm{x}$ & $x$ & & $x$ & $x$ & $\mathrm{x}$ & & & $\mathrm{x}$ \\
\hline Plaatsen en ingraven elektriciteitskabel (zee) & & $\mathrm{x}$ & $\mathrm{x}$ & $x$ & & & & $\mathrm{x}$ & & & $\mathrm{x}$ \\
\hline $\begin{array}{l}\text { Plaatsen en ingraven elektriciteitskabel (strand en } \\
\text { duin) }\end{array}$ & & $\mathrm{x}$ & $\mathrm{x}$ & & & & & & & & $x$ \\
\hline Plaatsen Slow Mill-converter & & $x$ & $x$ & $x$ & & & $x$ & $x$ & & & $x$ \\
\hline Graafwerkzaamheden & & $x$ & $x$ & & & & & & & & $x$ \\
\hline Vaarwerkzaamheden & & $x$ & $x$ & $x$ & & & & & & & $x$ \\
\hline \multicolumn{12}{|l|}{ Operationele fase } \\
\hline $\begin{array}{l}\text { Slow Mill-pilotinstallatie (anker en converter) in } \\
\text { werking }\end{array}$ & $x$ & $x$ & & $x$ & $x$ & $x$ & $x$ & & $x$ & & \\
\hline Markeringsboeien (aanwezigheid) & & $x$ & & & & & & & & & \\
\hline Elektriciteitskabel (aanwezigheid) & $x$ & & & & & & & & & $\mathrm{x}$ & \\
\hline Vaarwerkzaamheden (onderhoud en onderzoek) & & $x$ & $x$ & $x$ & & & & & & & $x$ \\
\hline \multicolumn{12}{|l|}{ Ontmantelingsfase } \\
\hline $\begin{array}{l}\text { Opruimen Slow Mill-pilotinstallatie (inclusief kabel; zie } \\
\text { hoofdstuk } 3 \text { en tabel 1) }\end{array}$ & & $\mathrm{x}$ & $\mathrm{x}$ & & $x$ & $x$ & & $\mathrm{x}$ & & & \\
\hline Vaarwerkzaamheden & & $x$ & $x$ & $x$ & & & & & & & $x$ \\
\hline
\end{tabular}

In elk van de drie fasen van de activiteiten kunnen er mogelijk negatieve effecten optreden op de natuurdoelen in het studiegebied. In de bouwfase treden de meeste verstoringsfactoren op. Deze zijn dan echter korter van duur dan in de operationele fase. In de ontmantelingsfase zijn de minste soorten effecten te verwachten.

De literatuur over WECs is gescreend op bevindingen over alle verstoringsfactoren uit tabel 4, exclusief stikstofdepositie. Deze worden per verstoringsfactor beschreven in onderstaande paragrafen. Dan wordt de relevantie van de verstoringsfactoren duidelijker, alsmede welke soorten en habitattypen daarvoor gevoelig zijn.

\subsection{Mogelijke effecten o.b.v. literatuuronderzoek}

Voor de weergave van de stand van kennis omtrent effecten van WECs (en bij uitbreiding stromingsen getijdeturbines) op de natuur, en hoe die kunnen worden vermeden of verminderd, is de literatuur op deze onderwerpen onderzocht. In Google Scholar en de Scopus-database is gezocht naar technische rapporten en peer-reviewed artikelen over sterfte, habitatverlies en mitigatie van de vier soortgroepen (vogels, vleermuizen, zeezoogdieren en vissen) in relatie tot energie-infrastructuur die vergelijkbaar is met de Slow Mill-installatie. Hierbij hebben we zoektermen gebruikt die betrekking hebben op de energie-infrastructuur in combinatie met soortgroepen. Er is voornamelijk gezocht op rapporten/artikelen van na 2015. De gebruikte zoektermen werden gesteld in het Engels, zoals 'wave energy converter', 'wave stream power' en 'tidal power' in combinatie met 'habitat', 'birds',

'mammals', 'fish', 'benthos', 'environmental effect', 'ecological effect', 'mitigation', 'underwater noise', 
en variaties hierop, gebruikmakend van andere namen van soortgroepen, maar er werd ook gezocht met de naar Nederlands vertaalde termen.

In totaal hebben wij op deze manier ca. dertig referenties gevonden waarvan ongeveer de helft relevant werd bevonden voor deze voortoets en de beschrijving van effecten. Iedere referentie is gescreend en toegekend aan een of meer van de categorieën voor type hernieuwbare-marieneenergieconverter, type verstoringsfactor en beïnvloede soort, soortgroep of habitattype. Vervolgens is voor iedere referentie geregistreerd welk effect op de individuen, populatie of habitattype werd gevonden, of het een aangetoond of gesuggereerd effect was en, indien van toepassing, tot welke afstand vanaf de structuur het effect werd gemeten.

Golfenergieomvormers worden in de wetenschappelijke literatuur meestal wave energy converters (WECs) genoemd en deze zijn, net zoals tidal stream turbines, nog volop in ontwikkeling. Het aantal toepassingen is nog beperkt. Op dit moment zijn er nog geen full-scale operationele toepassingen van deze systemen (Copping \& Hemery, 2020). Er is nog weinig over eventuele effecten bekend, waardoor er ook nog een grote mate van onzekerheid is onder onderzoekers, regelgevers en stakeholders over de effecten van WECs op het ecosysteem. De kans van optreden van effecten en de mate waarin zij zich doen gelden zal afhankelijk zijn van het werkingstype (statisch of dynamisch), en de ruimtelijke schaal van een WEC (enkelvoudig of een stelsel; Copping \& Hemery, 2020).

De vergelijking tussen de WECs die in de literatuur beoordeeld zijn, en de Slow Mill is niet integraal en zondermeer te maken, daarvoor zijn de installaties te verschillend. Op deelaspecten is de vergelijking echter wel te maken.

\subsubsection{Botsingen en verstrikkingen}

Er zijn meerdere rapporten en artikelen die botsingen beschrijven als potentieel effect van WECs op vissen, zeezoogdieren en duikvogels. Grecian et al. (2010) merken op dat botsingen met het bovenwaterdeel van een WEC minimaal zullen zijn door het lage profiel ervan. Botsingen met het onderwaterdeel van een WEC daartegen worden wel als een reëel risico gezien. Ook Witt et al. (2012), Copping \& Hemery (2020) en Furness et al. (2012) geven aan dat het onderwaterdeel van een WEC een potentieel negatief effect door botsingen kan opleveren, specifiek voor duikvogels. Bij gebrek aan veldwaarnemingen en beperkt wetenschappelijk bewijs (Furness et al., 2012; Copping \& Hemery, 2020 ) is er echter enige onzekerheid over het daadwerkelijke effect.

Verstrikkingen in kabels wordt meermaals als potentieel effect beschreven voor vissen en zeezoogdieren (Witt et al., 2012) en walvissen (Copping \& Hemery, 2020).

Aangenomen wordt dat de verschillen tussen de in de literatuur beschouwde WEC-installaties en de Slow Mill-pilotinstallatie niet zo zeer in de bekabeling en verankering zullen zitten, immers elke drijvende WEC-installatie moet met de bodem verankerd worden. De factor botsingen en verstrikkingen is dus niet op voorhand en met zekerheid uit te sluiten.

\subsubsection{Optische verstoring}

Er zijn twee publicaties gevonden die specifiek gaan over (optische) verstoring van zeevogels door WECs. Furness et al. (2012) melden mogelijke effecten, maar Lees et al. (2016) vonden geen negatieve effecten van WECs op het habitatgebruik.

De werkzaamheden ten behoeve van de installatie van de Slow Mill (anker en converter) en het leggen van de kabel kunnen door de aanwezigheid en de bewegingen van schepen en mensen (silhouetwerking) en de daarbij geproduceerde geluiden leiden tot een tijdelijke verstoring van de in het gebied aanwezige fauna. Effecten van optische verstoring en geluid kunnen vaak niet van elkaar worden onderscheiden. Daarom verwijzen wij hierbij ook naar de volgende paragraaf over verstoring door geluid (paragraaf 5.2.3). Ook verlichting is een vorm van optische verstoring. Voor de veiligheid van de scheepvaart worden er vaarmarkeringen in de vorm van boeien geplaatst op $500 \mathrm{~m}$ van de 
Slow Mill-pilotinstallatie. In de overwegend donkere Noordzeekustzone kan dit licht 's nachts verstoring veroorzaken voor vogels, zeezoogdieren en vissen.

De bouw- en ontmantelingswerkzaamheden zullen een kortstondige verstoring geven. De installatie zelf kan vanaf plaatsing wel gedurende de gehele testperiode en exploitatiefase optische verstoring veroorzaken. De beschermde zeehonden en vogelsoorten zijn gevoelig voor verstoring door de bewegingen van mensen en materieel. Tijdens deze werkzaamheden kunnen aanwezige dieren binnen een soort-specifieke verstoringafstand door bewegingen tijdelijk verstoord worden en vervolgens het plangebied en de omgeving (dus het studiegebied) voor een langere of kortere periode mijden. $\mathrm{Na}$ afloop van de werkzaamheden stopt de verstoring en kunnen de dieren het gebied weer gebruiken. Hierbij dient opgemerkt te worden dat er ook gewenning kan optreden, waardoor sommige individuen na verloop van tijd gebiedsvreemde objecten dichter gaan benaderen. Gewenning is geconstateerd bij zeehonden en sommige vogelsoorten, maar voor WECs zijn, voor zover wij weten, nog geen waarnemingen van gewenning gerapporteerd.

Verstoring van zeezoogdieren door bewegingen van schepen varieert per type en grootte van het schip, waarbij een maximale reikwijdte van $700 \mathrm{~m}$ kan worden aangehouden volgens Pondera Consult (2018). Dat geldt ook voor geluid boven water; zie 5.2.3.

Vogelsoorten van open water zijn vaak gevoeliger voor verstoring dan de vogelsoorten van stranden, duinen en droogvallende platen. In tabel 5 is een overzicht gemaakt van de vluchtafstanden van relevante vogelsoorten. De meest verstoringsgevoelige vogelsoorten zijn zwarte zee-eend en roodkeelduiker/parelduiker, met vluchtafstanden van respectievelijk $1500 \mathrm{~m}$ en 500-2000 m (Krijgsveld et al., 2008). In de regel wordt voor verstoring van zeevogels een maximale reikwijdte van $1500 \mathrm{~m}$ aangehouden (Pondera Consult, 2018). Vogelsoorten op droge gebieden (strand e.d.) worden verstoord binnen een afstand van maximaal $300 \mathrm{~m}$ van de bron (mensen of gebiedsvreemde objecten) en vluchten binnen een afstand van maximaal $125 \mathrm{~m}$. Dit is afhankelijk van de vogelsoort (Krijgsveld et al., 2008, Jongbloed et al., 2011).

Tabel 5 Verstoringsgevoeligheid van vogels die foerageren en rusten in het studiegebied. De aangegeven afstanden zijn gebaseerd op Krijgsveld et al. (2008). Nb = niet bekend.

\begin{tabular}{|l|c|c|}
\hline Instandhoudingsdoelstelling & $\begin{array}{c}\text { Vluchtafstand } \\
\mathbf{( m )}\end{array}$ & $\begin{array}{c}\text { Alertafstand } \\
\mathbf{( m )}\end{array}$ \\
\hline A001 - Roodkeelduiker & & $\mathrm{nb}$ \\
\hline A002 - Parelduiker & $500-2000$ & $\mathrm{nb}$ \\
\hline A017 - Aalscholver & $500-2000$ & 150 \\
\hline A048 - Bergeend & 75 & $\mathrm{nb}$ \\
\hline A062 - Topper & $102-380$ & $\mathrm{nb}$ \\
\hline A063 - Eider & 500 & $\mathrm{nb}$ \\
\hline A065 - Zwarte zee-eend & $\mathrm{nb}$ & $\mathrm{nb}$ \\
\hline A130 - Scholekster & 1500 & 175 \\
\hline A132 - Kluut & 100 & 250 \\
\hline A137 - Bontbekplevier & 75 & 175 \\
\hline A141 - Zilverplevier & 100 & 175 \\
\hline A143 - Kanoet & 100 & 300 \\
\hline A144 - Drieteenstrandloper & 125 & 300 \\
\hline A149 - Bonte strandloper & 125 & 300 \\
\hline A157 - Rosse grutto & 125 & 300 \\
\hline A160 - Wulp & 125 & $\mathrm{nb}$ \\
\hline A169 - Steenloper & 125 & \\
\hline A177 - Dwergmeeuw & & \\
\hline
\end{tabular}


Het grootste deel van het traject van de aan te leggen elektriciteitskabel voor de Slow Millpilotinstallatie bevindt zich op een dermate grote afstand ( $>300 \mathrm{~m}$ ) tot de grens van het Natura 2000-gebied Duinen en Lage Land Texel (zie paragraaf 3.1 en figuur 9) dat vogels die zich in dat gebied bevinden, niet of niet noemenswaardig worden verstoord door de aanwezigheid van machines en de mensen die de elektriciteitskabel aanleggen. Een deel van het kabeltraject loopt echter vlak langs de grens van Natura 2000-gebied Duinen en Lage Land Texel. Dat betreft het traject langs/onder de Badweg naar de parkeerplaats (De Koog) over een afstand van circa $200 \mathrm{~m}$ of over een afstand van circa $400 \mathrm{~m}$ naar de bebouwde kom (figuur 9). De Badweg is een strandopgang en wordt regelmatig druk bezocht door recreanten. De verwachting is dat de werkzaamheden voor de aanleg van de kabel geen extra verstoring van vogels zullen veroorzaken.

Op basis van de literatuur concluderen wij dat optische verstoring van vogels en zeezoogdieren niet kan worden uitgesloten voor de activiteiten in de bouwfase (plaatsen van anker, elektriciteitskabel en de Slow Mill-converter) alsmede in de operationele fase van de Slow Mill-pilotinstallatie.

\subsubsection{Verstoring door geluid (boven water)}

Er is één studie gevonden in de literatuur die specifiek ingaat op de mogelijke effecten van de WECs via bovenwatergeluid, namelijk Witt et al. (2012). Hierin wordt vermeld dat negatieve effecten door geluid (boven en onder water) tijdens de bouwfase van WECs op zeezoogdieren, vogels en vissen mogelijk zijn.

Tijdens het plaatsen van het anker, de elektriciteitskabel (met bijkomende graafwerkzaamheden) het plaatsen van de converter, en het onderhouden en later weer ontmantelen van de Slow Millpilotinstallatie, inclusief alle daarmee gepaard gaande vaarwerkzaamheden, vindt verstoring door geluid boven water plaats. Vogelsoorten zullen gevoelig zijn voor de verstoring door het geluid van de schepen en de graafmachine. Deze verstoringen treden meerdere malen op, in de periode maart-mei (zie tabel 1), maar zijn niet van lange of permanente duur. Het inregelen van de installatie en latere onderhoudswerkzaamheden vinden gespreid plaats. Als de werkzaamheden gestopt zijn, stopt ook de geluidsverstoring en kunnen vogels en andere dieren het gebied weer gebruiken.

Onderdelen in de horizontale drijver waar de generator zich bevindt, kunnen ook geluiden maken wanneer de installatie in werking is, dus permanent, maar het is niet te verwachten dat die geluiden buiten de behuizing treden.

Wij concluderen dat effecten van bovenwatergeluid in alle fases mogelijk zijn, met name in de bouwfase De verwachting is dat deze effecten niet groot zijn en stoppen zodra de werkzaamheden beëindigd zijn.

\subsubsection{Verstoring door geluid (onder water)}

Er is een aantal publicaties beschikbaar over de emissie van onderwatergeluid van WECs en de mogelijke effecten daarvan op mariene vissen en zoogdieren (Probert \& Mitchell (1983, Witt et al. (2012), Tougaard (2015), Buscaino et al. (2019), Haikonen et al. (2013), Copping et al. (2014), Copping \& Hemery (2020). Het beeld dat hieruit ontstaat is gevarieerd, namelijk van waarschijnlijk geen effect tot wel een effect van onderwatergeluid op vissen en zoogdieren, maar het is duidelijk dat er nog veel onbekend is en onderzocht zou moeten worden om hierover harde uitspraken te kunnen doen. De ernst van eventuele effecten is voor een belangrijk deel afhankelijk van het type constructie en de mate waarin onderwatergeluid wordt geproduceerd.

Geluid wordt geproduceerd door het raken van mechanische/geveerde eindstops. De Slow Millpilotinstallatie heeft echter een hydraulische cilinder waar hydraulische eindbuffers in zitten waardoor er geen mechanische klappen kunnen ontstaan. De lamellen in het bovenste deel van Slow Mill waarover de waterstroom wordt geleid, hebben een vleugelprofiel en zijn niet beweeglijk. Het draaipunt op het anker zal bij voldoende onderhoud geen geluid door mechanische wrijving opleveren. Andere bronnen van geluidsvorming zijn niet aannemelijk. Metingen ter plaatse naar de 
geluidsproductie van de Slow Mill-pilotinstallatie onder en boven water zouden duidelijkheid kunnen geven.

In de voorgaande paragrafen over optische verstoring en bovenwatergeluid is al vermeld dat verschillende bouw-, onderhouds- en ontmantelingsactiviteiten rond de Slow Mill-pilotinstallatie ook onderwatergeluid produceren. Bij het plaatsen van het anker, de elektriciteitskabel en de converter, en het onderhouden van de Slow Mill-installatie vindt verstoring door onderwatergeluid van werkschepen plaats, en mogelijk door de toegepaste antifouling-technieken (zie paragraaf 3.2). Zeezoogdieren en vissen zijn gevoelig voor verstoring door onderwatergeluid, kunnen ervan schrikken. Er zijn geen algemeen geaccepteerde drempelwaarden voor verstoring van zeezoogdieren, waarbij dieren het gebied als gevolg van (continu) onderwatergeluid veroorzaakt door schepen verlaten of vermijden (Pondera Consult 2018). De maximale verstoringsafstand van continu onderwatergeluid voor zeezoogdieren is kleiner dan $5 \mathrm{~km}$, waardoor de maximale reikwijdte van $5 \mathrm{~km}$ als worst casescenario voor de Slow Mill-pilotinstallatie en de benodigde werkschepen kan worden aangehouden. De verstoring door de werkschepen is van korte duur, en de zeezoogdieren en vissen kunnen na de korte verstoring terugkeren in het niet langer verstoorde gebied. Onze verwachting is dat het onderwatergeluid van de activiteiten voor installatie, onderhoud en ontmanteling van de Slow Mill-pilotinstallatie alleen tot tijdelijke effecten zal leiden die verwaarloosbaar zullen zijn vanwege de aanwezigheid van bestaande activiteiten in het studiegebied (denk aan de nabije scheepvaartroute en visserij). De belasting door continu-geluid is echter niet goed in te schatten en daardoor niet uit te sluiten.

\subsubsection{Verandering golfslag}

Er zijn meerdere studies gedaan naar de veranderingen van hydrodynamische processen door WECs (O'Brien et al., 2015; Copping et al., 2014; Contardo, 2018; Tomey-Bozo et al.,2019). Aangenomen wordt dat het effect van verandering van de golfslag bij kleine aantallen Marine Renewable Energy (MRE)-installations (NL: hernieuwbare mariene energie installaties) minimaal is of zelfs wegvalt binnen de natuurlijke variatie, maar meetwaarden uit het veld zijn nodig bij toepassing van grootschalige sets aan MREs om dit te onderbouwen (Copping \& Hemery, 2020).

Er zijn twee publicaties gevonden waarin het effect van golfslagverandering door WECs op het ecosysteem is onderzocht, namelijk indirecte effecten op zeevogels (Grecian et al. (2010) en een verandering van fytoplanktonsamenstelling (Witt et al. (2012).

In de operationele fase zal de golfslag achter de Slow Mill-pilotinstallatie gereduceerd zijn, maar de mate waarin is niet bekend. Gereduceerde golfslag en waterstroming zorgen voor een verminderde erosie en verhoogde sedimentatie in het gebied achter de pilotinstallatie. Of dit doorwerkt naar de Texelse kust waar de Slow Mill-installatie in theorie voor kustbescherming zou kunnen zorgen, is niet bekend. Daarnaast zal door de verminderde golfslag de aanvoer van nutriënten en planktonrijk water verminderen, wat een lokaal negatief effect kan hebben op de biodiversiteit en beschikbaarheid van voedsel voor vissen, zeezoogdieren en vogels. De Slow Mill-locatie voor de kust van Texel wordt gekenmerkt door behoorlijk extreme condities met tijdelijk hoge stroomsnelheden en veel golfwerking (Witbaard \& Wagemaakers, 2020). Een enkele set zal geen grootschalig verstrekkend effect op de omgeving hebben, maar bij een meer grootschalige uitrol van Slow Mill-energiesystemen zouden die effecten echter wel meer kunnen uitstralen door golfdemping en remming van de stroming, omdat de Slow Mill-installaties relatief dicht bij de kust en op geringe waterdiepte komen te staan (Witbaard \& Wagemaakers, 2020). Deze voortoets gaat echter niet over een verdere uitrol van Slow Millinstallaties.

\subsubsection{Verandering dynamiek substraat}

In de literatuur is aan de verandering van de dynamiek van substraat door WECs enige aandacht besteed, maar er is gebrek aan onderzoeksgegevens. Sommige studies vonden een duidelijk effect (Probert \& Mitchell, 1983), andere weinig effect (Langhammer, 2010) of een effect dat varieerde van klein tot groot, afhankelijk van de omvang van de WEC of het veld aan WECs (Copping et al., 2014), Copping \& Hemery (2020). 
Het plaatsen van de Slow Mill-converter en het bijbehorende anker op de zeebodem verandert de waterstroming en de sedimentatie en dus de lokale dynamiek van het substraat. De mate van de verandering zal afhankelijk zijn van meerdere factoren, zoals de bestaande omstandigheden en het type en de omvang van de WEC of het veld van WECs. De Slow Mill-installatie staat relatief dicht bij de kust en op geringe waterdiepte waar zeer energierijke condities overheersen. Het is niet te verwachten dat een enkel Slow Mill-systeem (gesuspendeerd energie-absorberend systeem en het betonnen anker) de hydrografie op grote schaal voor de kust van Texel zal veranderen. Bij een grootschalige uitrol van Slow Mill energiesystemen zouden die duidelijke effecten kunnen uitstralen door golfdemping en remming van de stroming, sedimentatie en re-suspensiekarakteristieken (Witbaard \& Wagemaakers, 2020). Er is dus sprake van een schaaleffect waarvan de gevoeligheid nog niet bekend is.

\subsubsection{Introductie hard substraat}

In de literatuur zijn een aantal publicaties beschikbaar over het potentiële effect van de introductie van hard substraat door WECs en deze melden vaak positieve effecten en soms negatieve effecten, of een combinatie van beide (Grecian et al., 2010); Probert \& Mitchell, 1983; , Witt et al., 2012; Nall et al., 2017; , Haikonen et al., 2013; , Copping \& Hemery, 2020).

Met het plaatsen van de Slow Mill-pilotinstallatie en het bijbehorende anker op de zeebodem wordt er een nieuw hard substraat gecreëerd wat voor een verhoging van de lokale biodiversiteit kan zorgen. Dit zal vissen aantrekken en daarmee in potentie ook zeezoogdieren en (duik)vogels. Dit heeft een positief effect op de biodiversiteit. Echter tegelijkertijd gaat er een oppervlakte verloren van het bestaande habitattype 'permanent overstroomde zandbanken' (H1110B) dat bestaat uit zachte zeebodem. Tevens kan er een verhoogd risico op botsingen van vissen en zeezoogdieren en duikende zeevogels optreden met de WEC. Vertroebeling en verontreiniging zijn andere verstoringsfactoren die gepaard gaan met de introductie van de structuren. Deze verstoringsfactoren worden in de overige paragrafen behandeld. Het is echter onduidelijk wat het netto-effect van al deze verstoringsfactoren op de natuur zal zijn. Daarnaast wordt een nieuw habitattype geïntroduceerd dat niet binnen het beheer van de Noordzeekustzone hoort. Men dient te beseffen dat het anker bij het plaatsen van de Slow Mill-converter omhooggehaald moet worden wat de ontstane biodiversiteit negatief kan aantasten. Aan het eind van de pilot wordt het anker weer verwijderd en dit nieuw ontstane habitat verdwijnt dan geheel en de dynamiek zal opnieuw drastisch veranderen (terugkeren naar de situatie van voor de plaatsing). Een permanent park van Slow Mill-installaties met hun ankers kan wel een permanent nieuw habitat met verhoogde biodiversiteit creëren. Een andere verandering van substraat kan ontstaan doordat er binnen een veiligheidszone van circa $30 \mathrm{~m}$ rond de Slow Mill geen andere activiteiten mogen plaatsvinden. In het geval dat bodem-beroerende visserij wegvalt, kan dat mogelijk een positief effect hebben op de lokale biodiversiteit. Overigens kan het netto-effect binnen de veiligheidszone negatief zijn door de aanwezigheid van negatieve effecten van andere verstoringsfactoren zoals zojuist beschreven. Een voorspelling van het netto-effect is moeilijk te geven. Het gebied waarop dit effect betrekking heeft is echter zeer klein.

Witbaard et al. (2020) hebben experimenteel onderzoek gedaan naar het effect van het plaatsen van hard substraat op de biodiversiteit op de locatie voor de Slow Mill-pilotinstallatie die op $4 \mathrm{~km}$ ten westen van Texel ligt op een waterdiepte van 12-14 m. Zij hebben bemonsteringen gedaan van de bodemfauna en de aangroei op een meetframe. Hun conclusies waren (geciteerd):

- $\quad$ "De Slow Mill locatie wordt gekenmerkt door een fauna die van nature arm aan soorten is die in lage dichtheden voorkomen.

- De dichtheden en het aantal aangetroffen soorten in de natuurlijke zandbodem is sterk seizoens afhankelijk.

- Het kortstondig (3 maanden) plaatsen van een hard substraat object in deze ondiepe kustzone leidt tot vestiging van 18 soorten die niet in de zandbodem worden gevonden. Afhankelijk van het seizoen leidt dat tot een verhoging van de lokale biodiversiteit van tussen de 36 en $51 \%$.

- De dichtheden organismen zijn op het hardsubstraat $400 \%$ hoger dan in de natuurlijke zandbodem. 
- Bij grootschalige plaatsing van hardsubstraat in deze ondiepe kustzone valt op grond van deze resultaten te verwachten dat op lokale schaal biodiversiteit en secundaire productie toenemen."

Witbaard \& Wagemaakers (2020) verwachten dat de ontwikkeling en het eindstadium van de hardsubstraatgemeenschap op de Slow Mill-locatie sterk door de extreme abiotische condities met tijdelijk hoge stroomsnelheden en veel golfwerking zal worden beïnvloed, waardoor de aangroei relatief arm aan soorten zal blijven, alhoewel de totale biodiversiteit (zacht en hard substraat) dus wel aanmerkelijk toenam.

\subsubsection{Vertroebeling}

Specifiek met betrekking tot WECs is de publicatie van Witt et al. (2012) van belang, waarin wordt beschreven dat door vertroebeling, net als bij de soms ook optredende golfslagvermindering en verstoring van het sediment, er veranderingen in de samenstelling en de dichtheid van plankton kunnen optreden.

Bij het plaatsen van het anker, de elektriciteitskabel en het plaatsen en ontmantelen van de Slow Millinstallatie zal er vertroebeling van het water ontstaan. Vertroebeling betreft een toename van gesuspendeerd materiaal in de waterkolom. Een verhoogde troebelheid kan effect hebben op de primaire productie (algenbloei), zeker in de periode van de bouwfase die midden in de voorjaarsbloei van fytoplankton valt. Daarnaast kan vermindering van zicht voor zichtjagers veroorzaakt worden en kan de vertroebeling leiden tot verstopping van ademhalingsorganen en het verzamelen van voedsel van filter feeders verstoren. Desondanks is de vertroebeling zeer lokaal en van beperkte tijdsduur en zijn dergelijke effecten (naar wij weten) nog nooit in het veld gemeten. Mede vanwege de hoge hydrodynamiek ter plaatse is het slechts een beperkte extra vertroebeling. Wij concluderen dat een eventueel negatief effect dat van vertroebeling uitgaat altijd verwaarloosbaar zal zijn.

\subsubsection{Verontreiniging (toxische stoffen)}

Witt et al. (2012) noemden de mogelijkheid dat toxische antifouling op WECs de mortaliteit van plankton kunnen verhogen. De Slow Mill-pilotinstallatie wordt niet uitgerust met een aangroeiremmende coating, ook zgn. zelfslijpende antifouling wordt niet toegepast, wel zullen er verschillende typen antifouling-technieken worden gebruikt (zie paragraaf 3.2). De wrapping-folie en micro-haartjes (finsulate) kunnen loskomen en zijn een vorm van fysiek afval (litter). Op basis van dat laatste concluderen wij dat negatieve effecten van verontreiniging niet kunnen worden uitgesloten.

\subsubsection{Elektromagnetische straling}

De effecten van elektromagnetische straling door de bekabeling van WECs is nog niet voldoende bekend of ingeschat (Witt et al., 2012; Haikonen et al., 2013), terwijl Copping \& Hemery (2020) concluderen dat effecten van elektromagnetische straling (door elektrakabels) van de huidige kleine en enkelvoudige WECs op benthische marine organismen waarschijnlijk minimaal zullen zijn.

De Slow Mill-pilotinstallatie heeft maar één kabel wat in vergelijking met bv. windmolenparken (Witt et al., 2012) weinig is. Kabels produceren een elektromagnetisch veld dat mogelijk negatieve effecten op vissen en zeezoogdieren kan veroorzaken, afhankelijk van de sterkte van dat elektromagnetische veld. Het spanningsniveau van de transportkabel van de Slow Mill-pilotinstallatie is $10 \mathrm{kV}$. Dit is veel lager dan het spanningsniveau van offshore-windparken. Het Transformatiesysteem Op Zee Hollandse Kust Zuid (TOZ-HKZ) bv. heeft vanaf de platforms twee 220 kV-kabels naar de kust (Pondera Consult, 2018). De maximale reikwijdte van de TOZ-HKZ kabel wordt als minimaal (enkele meters tot $15 \mathrm{~m}$ ) ingeschat (Pondera Consult, 2018).

Omdat er voor deze verstoringsfactor een grote kennislacune is, kunnen potentieel negatieve effecten van elektromagnetische straling door de elektriciteitskabel van de Slow Mill-pilotinstallatie niet worden uitgesloten. 


\subsubsection{Stikstofdepositie}

Bij het varen tussen de locatie voor de Slow Mill-pilotinstallatie en de Kooyhaven en het ingraven van de kabel op het strand en in de duinen zal emissie van stikstof plaatsvinden door de verbrandingsmotoren van het ingezette materieel. Het is aannemelijk dat er enige mate van depositie van stikstof zal optreden op de vegetatie in de nabijheid, waaronder de habitattypen van Natura 2000-gebied Duinen en Lage Land Texel. De stikstofdepositie is gekwantificeerd met behulp van AERIUS-tool in hoofdstuk 7.

\subsubsection{Positieve effecten}

Er kunnen naast de potentieel negatieve effecten ook potentieel positieve effecten van de Slow Millpilotinstallatie op natuurwaarden optreden. In de literatuur zijn vermeldingen over (mogelijk) positieve effecten van WECs gevonden. Sommige daarvan zijn in de voorgaande paragrafen al kort beschreven, omdat positieve en negatieve effecten van WECs tegelijk kunnen komen. De potentieel positieve effecten van WECs worden in deze paragraaf gecompileerd. We merken hierbij wel op dat de positieve effecten in tegenstelling tot potentieel negatieve effecten, niet relevant zijn voor het verkrijgen van een Wnb-vergunning.

De positieve effecten hangen samen met de introductie van hard substraat in een omgeving waar zeer weinig natuurlijk (en onnatuurlijk) hard substraat aanwezig is. Dit gaat namelijk gepaard met:

- een toename van het aantal benthossoorten die leven op het artificieel substraat (Nall et al., 2017; Copping \& Hemery, 2020);

- $\quad$ een grotere voedselbeschikbaarheid voor vissen, duikende vogels, zeezoogdieren (Probert \& Mitchell, 1983; Witt et al., 2012);

- $\quad$ een plaatselijke toename van soorten vanwege rustplaatsen voor vogels (Grecian et al., 2010);

- $\quad$ en gekoppeld aan bovengenoemde veranderingen: een plaatselijke toename van de biodiversiteit (Nall et al., 2017; Witt et al., 2012; Haikonen et al., 2013; Witbaard et al., 2020). De ontwikkeling en het eindstadium van de hardsubstraat gemeenschap op de Slow Mill-locatie zal sterk door de extreme abiotische condities (tijdelijk hoge stroomsnelheden en veel golfwerking) worden beperkt, alhoewel de totale biodiversiteit (zacht en hard substraat) nog wel aanmerkelijk kan toenemen (Witbaard \& Wagemaakers, 2020).

Een positief neveneffect van de installatie van WECs is het weren van andere activiteiten in een veiligheidszone, bv. de verwijdering van bodem-beroerende visserij uit het gebied waardoor de zeebodem zich kan herstellen van deze activiteit (Witt et al., 2012).

In de bredere context is de opmerking van Copping et al. (2014) relevant dat bij de overwegingen van de milieueffecten van hernieuwbare energiewinning uit de zee het ook belangrijk is om te realiseren dat alle vormen van energieproductie gepaard gaan met milieukosten en deze dus met hun directe en indirecte milieueffecten tegen elkaar kunnen worden afgewogen.

\subsubsection{Overzicht van de bevindingen van de verstoringsfactoren}

Op basis van de hierboven geschetste bevindingen worden in deze paragraaf twee overzichtstabellen gepresenteerd. In tabel 6 wordt een overzicht gegeven van de verstoringsfactoren die relevant zijn vanwege de mogelijke negatieve effecten van de Slow Mill-pilotinstallatie op natuurdoelen van de Noordzeekustzone. Deze bevindingen worden in hoofdstuk 6 toegepast op de afzonderlijkje soorten en habitattypen die relevant zijn voor het onderhavige studiegebied. In een tweede overzicht (tabel 7) zijn dezelfde bevindingen voor de verschillende activiteiten en fases van het Slow Mill-pilotproject in beeld gebracht. 
Tabel 6 Overzicht van de conclusies over potentiële effecten van verstoringsfactoren van golfslagconvertoren (WECs) gebaseerd op literatuuronderzoek

\begin{tabular}{|c|c|c|c|c|c|c|c|c|c|c|}
\hline $\begin{array}{l}\text { Soortgroep/ } \\
\text { Habitat }\end{array}$ & 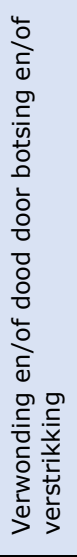 & 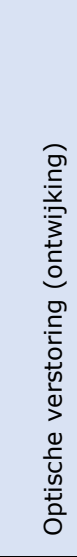 & 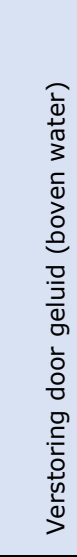 & 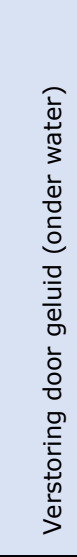 & 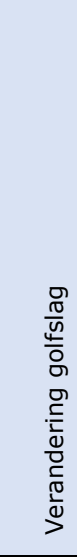 & 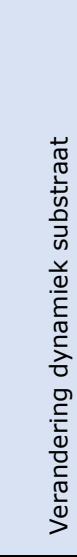 & 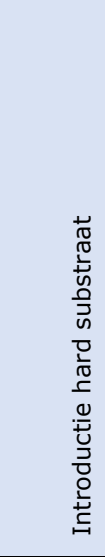 & 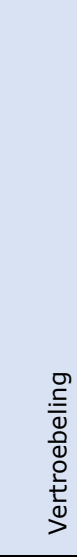 & 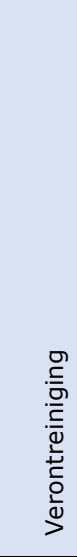 & 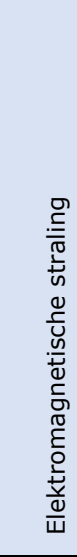 \\
\hline Vissen & $\mathrm{P}$ & & & $\mathrm{P}$ & & & Pos & & & $\mathrm{P}$ \\
\hline Zeezoogdieren & $\mathrm{P}$ & & & $\mathrm{P}$ & & & Pos & & & $\mathrm{P}$ \\
\hline Zeevogels & $\mathrm{P}$ & $P$ & $\mathrm{P}$ & & $\mathrm{P}$ & & Pos & & & \\
\hline Benthos & & & & & & & $\mathrm{P}$ & & & $\mathrm{P}$ \\
\hline Epibenthos & & & & & & & Pos & & & \\
\hline Habitat & & & & & $\mathrm{P}$ & $\mathrm{P}$ & Pos/P & $\mathrm{P}$ & $P$ & \\
\hline Biodiversiteit & & & & & & $\mathrm{P}$ & Pos & & & \\
\hline
\end{tabular}

\begin{tabular}{|c|l|}
\hline$P$ & Potentieel negatief effect \\
\hline Pos & Potentieel positief effect \\
\hline PoS/P & Potentieel positief of negatief effect \\
\hline & Geen potentieel effect \\
\hline
\end{tabular}


Tabel 7 Overzicht van de verstoringsfactoren die zich in de onderscheiden fases per activiteit van de Slow Mill-pilotinstallatie kunnen doen gelden. Aangegeven is de overlap in tijd en ruimte met aanwezige beschermde natuurwaarden en de verwachting omtrent een effect.

\begin{tabular}{|c|c|c|c|c|c|c|c|c|c|c|c|}
\hline Activiteiten & 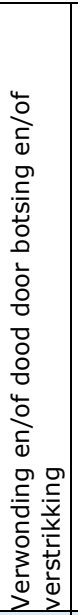 & 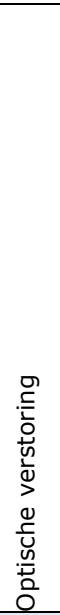 & 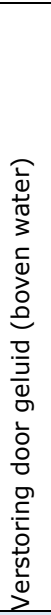 & 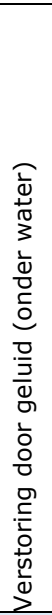 & 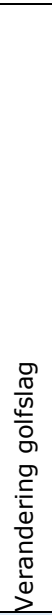 & 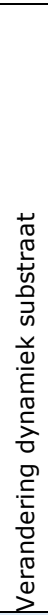 & 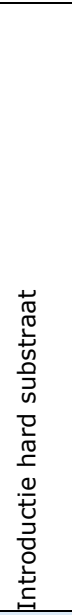 & 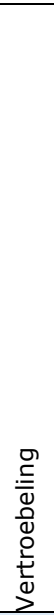 & 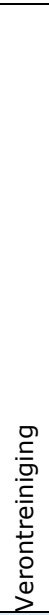 & 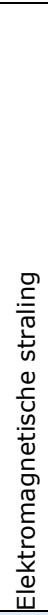 & 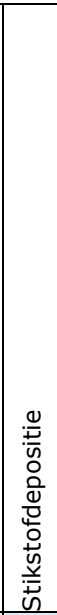 \\
\hline \multicolumn{12}{|l|}{ Bouwfase } \\
\hline Plaatsen elektriciteitskabel (zee) & & $\mathrm{P}$ & $\mathrm{P}$ & $\mathrm{P}$ & & & & & & & $\mathrm{P}$ \\
\hline Plaatsen elektriciteitskabel (strand en duin) & & & & & & & & & & & $\mathrm{P}$ \\
\hline Plaatsen anker & & $\mathrm{P}$ & $\mathrm{P}$ & & & & \begin{tabular}{|c|} 
Pos/ \\
P
\end{tabular} & & & & $\mathrm{P}$ \\
\hline Plaatsen van Slow Mill-converter & & $\mathrm{P}$ & $\mathrm{P}$ & & & & $\begin{array}{c}\text { Pos/ } \\
\text { P }\end{array}$ & & & & $\mathrm{P}$ \\
\hline Graafwerkzaamheden & & & & & & & & & & & $\mathrm{P}$ \\
\hline Vaarwerkzaamheden & & & & & & & & & & & $\mathrm{P}$ \\
\hline \multicolumn{12}{|l|}{ Operationele fase } \\
\hline Slow Mill-converter in werking & $P$ & $\mathrm{P}$ & & $\mathrm{P}$ & & & \begin{tabular}{|c|} 
Pos/ \\
P
\end{tabular} & & $\mathrm{P}$ & & \\
\hline \multicolumn{12}{|l|}{ Markeringsboeien } \\
\hline Elektriciteitskabel & & & & & & & & & & $\mathrm{P}$ & \\
\hline Vaarwerkzaamheden (onderhoud) & & & & & & & & & & & $\mathrm{P}$ \\
\hline \multicolumn{12}{|l|}{ Ontmanteling fase } \\
\hline \multicolumn{12}{|c|}{ Opruimen Slow Mill-installatie incl. anker en kabel } \\
\hline Vaarwerkzaamheden & & & & & & & & & & & $\mathrm{P}$ \\
\hline
\end{tabular}

Legenda:
\begin{tabular}{|c|l|}
\hline & Activiteit heeft geen overlap in ruimte en tijd met een beschermde natuurwaarde (habitattype of de soort) \\
\hline & $\begin{array}{l}\text { Activiteit heeft wel overlap in ruimte en tijd met een beschermde natuurwaarde (habitattype of de soort), maar } \\
\text { een effect is niet aannemelijk }\end{array}$ \\
\hline P & $\begin{array}{l}\text { Activiteit heeft wel overlap in ruimte en tijd met een beschermde natuurwaarde (habitattype of de soort), en } \\
\text { daarbij mogelijk een effect }\end{array}$ \\
\hline $\begin{array}{c}\text { Pos/ } \\
\text { P }\end{array}$ & $\begin{array}{l}\text { Activiteit heeft wel overlap in ruimte en tijd met een beschermde natuurwaarde (habitattype of de soort), en } \\
\text { daarbij mogelijk een effect dat positief of negatief kan zijn }\end{array}$ \\
\hline
\end{tabular}




\section{Effectbeoordeling}

In het voorgaande hoofdstuk is de relevante literatuur gescreend om de potentiële verstoringsfactoren van WECs met hun eventuele effecten op natuurwaarden te kennen. In dit hoofdstuk worden de potentiële effecten van de Slow Mill-pilotinstallatie beoordeeld in het licht van de Wnb, de Natura 2000-instandhoudingsdoelstellingen. Daarbij wordt de ruimtelijke en temporele aanwezigheid van de habitattypen en soorten nader in relatie tot de activiteiten van de Slow Mill-pilotinstallatie gebracht.

Een overzicht van de potentiële effecten op de relevante habitattypen, habitatsoorten, broedvogels en niet-broedvogels in het Natura 2000-gebied Noordzeekustzone is op de volgende bladzijden weergegeven. Hiervoor zijn kleurcoderingen gebruikt voor de onderscheiden categorieën van potentiële effecten en het eindoordeel betreffende het wel of niet kunnen uitsluiten van effecten op de instandhoudingsdoelen (tabel 8).

Effecten op de instandhoudingsdoelen van Natura 2000-gebied Duinen en Lage Land Texel worden uitgesloten geacht omdat de projectactiviteiten zich buiten de begrenzing van dat gebied bevinden en de werking van de verstoringsfactoren van die activiteiten niet zodanig is dat er blootstellingsniveaus worden bereikt waarbij effecten in dat gebied te verwachten zijn (externe werking). Een uitzondering wordt gemaakt voor de kleine mantelmeeuw van de broedkolonies op Texel die ook foerageert voor de kust van De Koog en waarvoor (in het kader van deze voortoets) een effect niet op voorhand kan worden uitgesloten. 
Tabel 8 Eindbeoordeling van de effecten die van de verschillende verstoringsfactoren als gevolg van de activiteiten voor de Slow Mill-pilotinstallatie kunnen uitgaan op instandhoudingsdoelen van de Noordzeekustzone

\begin{tabular}{|c|c|c|c|c|c|c|c|c|c|c|c|c|}
\hline Instandhoudingsdoelen & 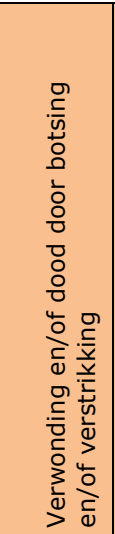 & 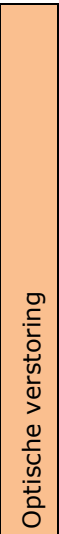 & 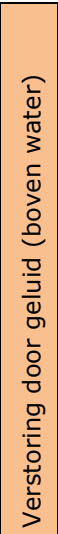 & 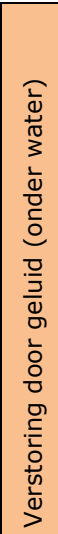 & 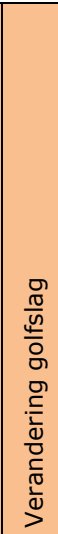 & 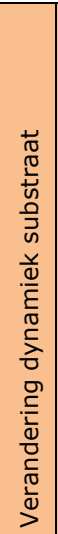 & 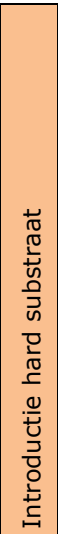 & 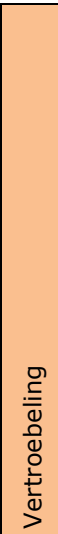 & 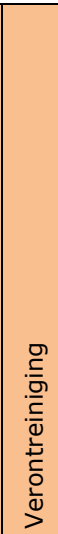 & 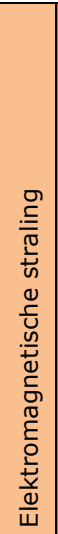 & 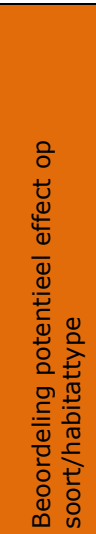 & 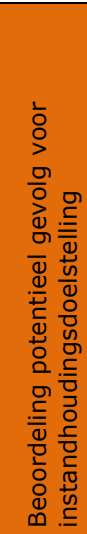 \\
\hline H1110B - Permanent overstroomde zandbanken & & & & & $\mathrm{V}$ & $\mathrm{V}$ & $\mathrm{x}$ & $\mathrm{v}$ & $\mathrm{V}$ & & $\mathrm{V}$ & $\mathrm{U}$ \\
\hline H1140B - Slik- en zandplaten & & & & & $\mathrm{x}$ & $\mathrm{x}$ & & & & & $\mathrm{V}$ & $\mathrm{U}$ \\
\hline H1310A - Zilte pionierbegroeiingen (zeekraal) & & & & & & & & & & & $\mathrm{G}$ & $U$ \\
\hline H1310B - Zilte pionierbegroeiingen (zeevetmuur) & & & & & & & & & & & $\mathrm{G}$ & $\mathrm{U}$ \\
\hline H1330A - Schorren en zilte graslanden (buitendijks) & & & & & & & & & & & $\mathrm{G}$ & $U$ \\
\hline $\mathrm{H} 2110$ - Embryonale duinen & & & & & & & & & & & $\mathrm{G}$ & $\mathrm{U}$ \\
\hline H2190B - Vochtige duinvalleien (kalkrijk) & & & & & & & & & & & $\mathrm{G}$ & $\mathrm{U}$ \\
\hline H1095 - Zeeprik & $\mathrm{x}$ & & & $\mathrm{V}$ & & & $\mathrm{V}$ & & & $\mathrm{V}$ & $\mathrm{P}$ & $\mathrm{P}$ \\
\hline H1099 - Rivierprik & $x$ & & & $\mathrm{v}$ & & & $\mathrm{V}$ & & & $\mathrm{v}$ & $\mathrm{P}$ & $\mathrm{P}$ \\
\hline H1103 - Fint & $x$ & & & $x$ & & & $\mathrm{~V}$ & & & $\mathrm{~V}$ & $P$ & $P$ \\
\hline H1351 - Bruinvis & $x$ & $?$ & & $x$ & & & $\mathrm{v}$ & & & $\mathrm{v}$ & $P$ & $P$ \\
\hline H1364 - Grijze zeehond & $x$ & $?$ & & $x$ & & & $\mathrm{v}$ & & & $\mathrm{v}$ & $\mathrm{P}$ & $\mathrm{P}$ \\
\hline H1365 - Gewone zeehond & $x$ & $?$ & & $x$ & & & $\mathrm{~V}$ & & & $\mathrm{v}$ & $\mathrm{P}$ & $\mathrm{P}$ \\
\hline A137 - Bontbekplevier & & $x$ & $x$ & & & & & & & & $\mathrm{G}$ & $\mathrm{U}$ \\
\hline A138 - Strandplevier & & $x$ & $x$ & & & & & & & & $\mathrm{G}$ & $U$ \\
\hline A195 - Dwergstern & & $x$ & $x$ & & $\mathrm{~V}$ & $\mathrm{~V}$ & $\mathrm{~V}$ & & $\mathrm{~V}$ & & $\mathrm{G}$ & $\mathrm{U}$ \\
\hline A001 - Roodkeelduiker & $x$ & $x$ & $x$ & & $\mathrm{~V}$ & $\mathrm{~V}$ & $\mathrm{~V}$ & & $\mathrm{~V}$ & & $P$ & $P$ \\
\hline A002 - Parelduiker & $x$ & $x$ & $x$ & & $\mathrm{~V}$ & $\mathrm{~V}$ & $\mathrm{~V}$ & & $\mathrm{~V}$ & & $\mathrm{P}$ & $\mathrm{P}$ \\
\hline A017 - Aalscholver & $x$ & $\mathrm{v}$ & $x$ & & $\mathrm{v}$ & $\mathrm{v}$ & $\mathrm{v}$ & & $\mathrm{v}$ & & $P$ & $P$ \\
\hline A048 - Bergeend & & $\mathrm{v}$ & $x$ & & & & & & & & $\mathrm{~V}$ & $\mathrm{U}$ \\
\hline A062 - Topper & $x$ & $x$ & $\mathrm{x}$ & & $\mathrm{v}$ & $\mathrm{v}$ & $\mathrm{v}$ & & $\mathrm{v}$ & & $\mathrm{V}$ & $\mathrm{U}$ \\
\hline A063 - Eider & $x$ & $x$ & $x$ & & $\mathrm{~V}$ & $\mathrm{v}$ & $\mathrm{v}$ & & $\mathrm{v}$ & & $\mathrm{P}$ & $\mathrm{P}$ \\
\hline A065 - Zwarte zee-eend & $\mathrm{x}$ & $x$ & $x$ & & $\mathrm{~V}$ & $\mathrm{~V}$ & $\mathrm{~V}$ & & $\mathrm{~V}$ & & $\mathrm{P}$ & $\mathrm{P}$ \\
\hline A130 - Scholekster & & $x$ & $x$ & & & & & & & & $\mathrm{~V}$ & $U$ \\
\hline A132 - Kluut & & $x$ & $x$ & & & & & & & & $\mathrm{~V}$ & $U$ \\
\hline A137 - Bontbekplevier & & $x$ & $x$ & & & & & & & & $\mathrm{~V}$ & $U$ \\
\hline A141 - Zilverplevier & & $x$ & $x$ & & & & & & & & $\mathrm{~V}$ & $\mathrm{U}$ \\
\hline A143 - Kanoet & & $x$ & $x$ & & & & & & & & $\mathrm{~V}$ & $U$ \\
\hline A144 - Drieteenstrandloper & & $x$ & $x$ & & & & & & & & $\mathrm{~V}$ & $\mathrm{U}$ \\
\hline A149 - Bonte strandloper & & $x$ & $\mathrm{x}$ & & & & & & & & $\mathrm{V}$ & $\mathrm{U}$ \\
\hline A157 - Rosse grutto & & $x$ & $x$ & & & & & & & & $\mathrm{~V}$ & $\mathrm{U}$ \\
\hline A160 - Wulp & & $x$ & $\mathrm{x}$ & & & & & & & & $\mathrm{V}$ & $\mathrm{U}$ \\
\hline A169 - Steenloper & & $\mathrm{V}$ & $\mathrm{x}$ & & & & & & & & $\mathrm{V}$ & $\mathrm{U}$ \\
\hline A177 - Dwergmeeuw & $\mathrm{x}$ & $x$ & $x$ & & $\mathrm{v}$ & $\mathrm{v}$ & & $\mathrm{v}$ & $\mathrm{V}$ & & $\mathrm{P}$ & $\mathrm{P}$ \\
\hline
\end{tabular}

Legenda

\begin{tabular}{|l|l|}
\hline Weergave & Effect van verstoringsfactor \\
\hline & Geen blootstelling \\
\hline $\mathrm{V}$ & Verwaarloosbaar effect \\
\hline $\mathrm{X}$ & Potentieel effect \\
\hline$?$ & Onbekend effect \\
\hline
\end{tabular}

\begin{tabular}{|l|l|}
\hline Weergave & Effect van alle verstoringsfactoren samen \\
\hline G & Geen effect \\
\hline V & Verwaarloosbaar effect \\
\hline P & Potentieel effect \\
\hline
\end{tabular}

\begin{tabular}{|l|l|}
\hline Weergave & Effectbeoordeling instandhoudingsdoelen \\
\hline$U$ & Significante effecten worden uitgesloten \\
\hline$P$ & Significante effecten kunnen niet worden uitgesloten \\
\hline
\end{tabular}




\subsection{Temporele aanwezigheid}

Een belangrijk deel van de informatie over de ruimtelijke en temporele verspreiding en de gevoeligheid van de Natura 2000-waarden in de Noordzeekustzone die in deze voortoets wordt gebruikt, is betrokken uit het rapport Natura 2000-doelen in de Noordzeekustzone-Van doelen naar opgaven voor natuurbescherming van Jak et al. (2014a, 2014b). Dit geldt ook voor tabel 99 waarin een overzicht wordt gegeven van het voorkomen van de natuurdoelen gedurende de maanden van het jaar. Voor de habitattypen zijn de kenmerken jaarrond aanwezig. Voor trekvissen geldt dat deze vrijwel het hele jaar aanwezig kunnen zijn, maar in bepaalde delen van het jaar door trekbewegingen van en naar de zoete wateren talrijker kunnen zijn. De bruinvis is het hele jaar aanwezig en onduidelijk is of er perioden zijn die van speciale betekenis zijn. Aantallen zijn in de Nederlandse kustwateren doorgaans lager in de zomer wanneer als de bruinvis wegtrekt naar voortplantingsgebieden. De twee zeehondensoorten zijn het hele jaar aanwezig in het water om te foerageren en maken het hele jaar door gebruik van platen om op te rusten. Platen worden ook opgezocht voor reproductie en verharing. Voor de grijze zeehond speelt zich dat af in de winter resp. voorjaar; voor de gewone zeehond in zomer resp. nazomer.

Het broedseizoen van de drie soorten broedvogels loopt ongeveer van april tot juli (tabel 9). De niet-broedvogels zijn in deze periode juist afwezig of in relatief lage aantallen aanwezig, tenzij vanuit broedgebieden gefoerageerd wordt in de Noordzeekustzone (zoals aalscholver en kluut). De overige niet-broedvogels zijn soorten die wintergast of doortrekker zijn en gebruiken de Noordzeekustzone vooral als slaapplaats, hoogwatervluchtplaats en/of foerageergebied.

De installatieactiviteiten voor de Slow Mill-pilotinstallatie zijn in de periode maart tot en met juli en de ontmanteling in de maand april (tabel 2 ). Dit is relatief gezien een gunstige periode om verstoring van niet-broedvogels te beperken (tabel 9). De maand maart is wat minder gunstig en daarom zou de start van de installatieperiode beter een maand kunnen worden opgeschoven naar april. Een uitloop van de installatieperiode naar augustus is niet ongunstig. 
Tabel 1 Overzicht van het temporele voorkomen van de Natura 2000-waarden in de Noordzeekustzone op basis van geraadpleegde literatuur (Doelendocumenten; SOVON, 2007; de Jong et al., 2010). Lichtgrijs = aanwezig; Donkerder grijs $=>25 \%$ t.o.v. maximum; Donkergrijs $=>50 \%$ t.o.v. maximum; Zwart = maand waarin maximum aantal aanwezig is

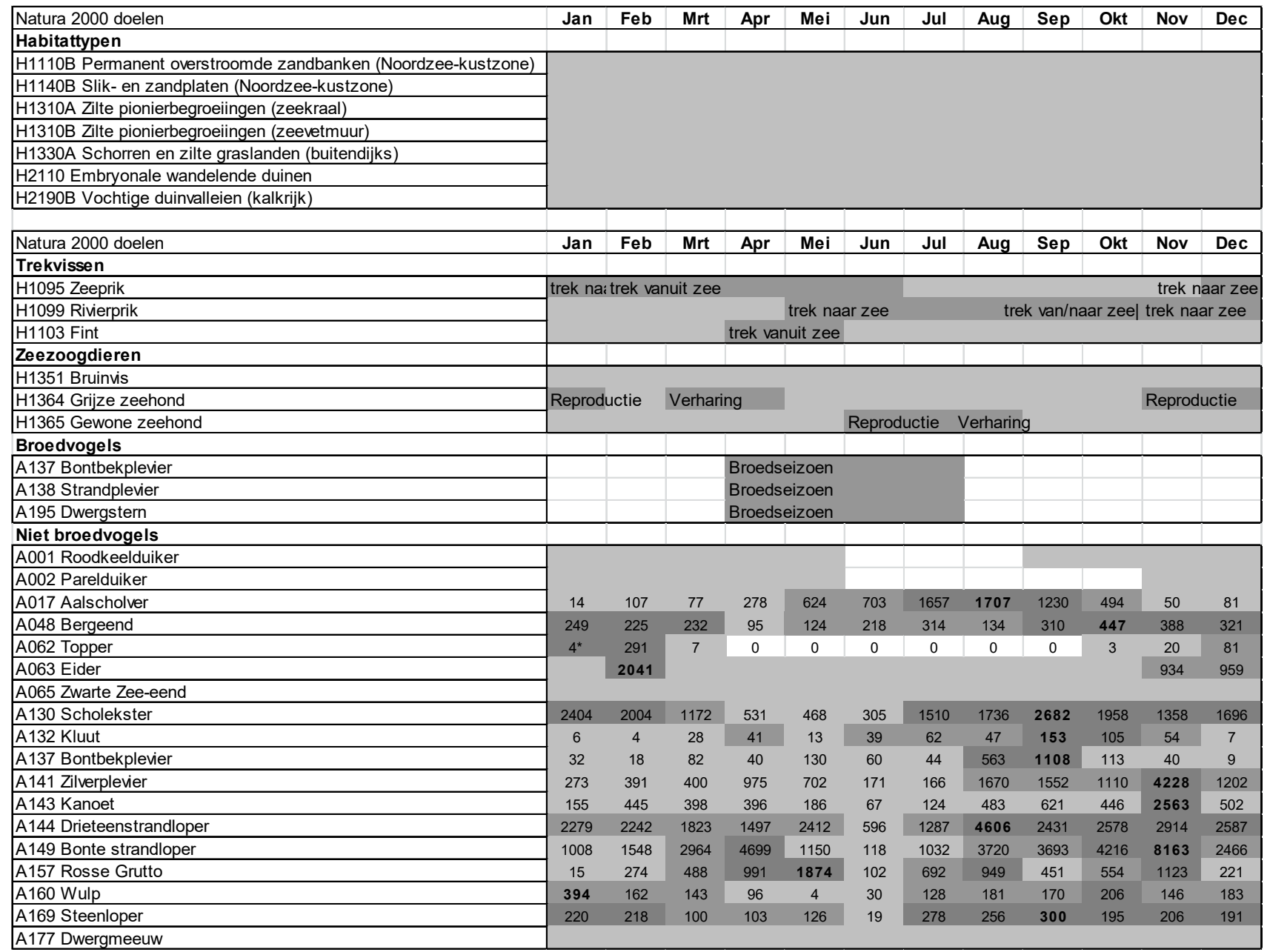

Jak et al. (2014b) hebben de samenhang tussen de afzonderlijke Natura 2000-waarden, kernopgaven en doelen met een sense of urgency geschetst in een tabel die gebruikt wordt bij deze voortoets (tabel 10). In die tabel is een koppeling van de Natura 2000-soorten en de habitattypen waarin zij voorkomen, aangebracht. 
Tabel10 Samenhang tussen habitattypen, soorten, functie van de gebieden en periodes van voorkomen van de soorten. $F=$ foerageergebied, $b=$ bodemdier, $p=$ plankton, $t=$ tweekleppige, $v=v i s$, $\mathrm{R}=$ rustgebied, $\mathrm{B}=$ broedgebied, $\mathrm{V}=$ voortplantingsgebied, $\mathrm{D}=$ doortrek/leefgebied. De doelen waarvoor een sense of urgency geldt, zijn onderstreept, bij de cursief weergegeven doelen betreft het een opgave m.b.t. watercondities, voor de overige geldt een opgave m.b.t. beheer. In blauw is de belangrijkste samenhang tussen de verschillende doelen weergegeven.

Voor de gewone zeehond geldt dat $\mathrm{H} 1140 \mathrm{~B}$ voor voortplanting van belang is in de zomer (juni-juli), voor de grijze zeehond in de winter (november-januari). Voor de bontbekplevier is $\mathrm{H} 2110$ als broedgebied van belang in de periode april-juli.

\begin{tabular}{|c|c|c|c|c|c|c|c|c|}
\hline \multirow[t]{2}{*}{ Habitattype } & Kernopgave & Soort & \multicolumn{5}{|c|}{ Functie } & \multirow{2}{*}{\begin{tabular}{|l} 
Periode \\
jaarrond
\end{tabular}} \\
\hline & \multirow{4}{*}{$\begin{array}{l}1.01 \text { Overstroomde } \\
\text { zandbanken }\end{array}$} & Eider & $\mathrm{F}$ & $\mathrm{t}$ & $\mathrm{R}$ & & & \\
\hline \multirow{13}{*}{$\begin{array}{l}\frac{\frac{H 1110 B}{\text { Permanent }}}{\text { overstroomde }} \\
\text { zandbanken }\end{array}$} & & Topper & $\mathrm{F}$ & $\mathrm{t}$ & $\mathrm{R}$ & & & winter \\
\hline & & Zwarte zee-eend & $\mathrm{F}$ & $\mathrm{t}$ & $\mathrm{R}$ & & & winter \\
\hline & & Roodkeelduiker & $\mathrm{F}$ & v & $\mathrm{R}$ & & & winter \\
\hline & & Aalscholver & $F$ & $\mathrm{v}$ & & & & jaarrond \\
\hline & & Dwergmeeuw & $\mathrm{F}$ & v & $\mathrm{R}$ & & & doortrek \\
\hline & & Dwergstern & $\mathrm{F}$ & $\mathrm{v}$ & & & & zomer \\
\hline & & Parelduiker & $F$ & v & $\mathrm{R}$ & & & winter \\
\hline & & Fint & $\mathrm{F}$ & $v / p$ & & & D & jaarrond \\
\hline & & Rivierprik & $\mathrm{F}$ & v & & & $\mathrm{D}$ & jaarrond \\
\hline & & Zeeprik & $F$ & v & & & $\mathrm{D}$ & jaarrond \\
\hline & & Bruinvis & $\mathrm{F}$ & $\mathrm{v}$ & & & & jaarrond \\
\hline & 1.02 Zeezoogdieren & Gewone zeehond & $\mathrm{F}$ & v & & & & jaarrond \\
\hline & & Grijze zeehond & $\mathrm{F}$ & $\mathrm{v}$ & & & & jaarrond \\
\hline \multirow{14}{*}{$\begin{array}{c}\text { H1140B } \\
\text { Slik- en zandplaten }\end{array}$} & & Steenloper & $F$ & $b$ & & & & winter \\
\hline & & Bergeend & $F$ & $b$ & $\mathrm{R}$ & & & jaarrond \\
\hline & & Bontbekplevier & $F$ & $b$ & & & & jaarrond \\
\hline & & Drieteenstrandloper & $\mathrm{F}$ & $\mathrm{b}$ & & & & winter \\
\hline & & Strandplevier & $\mathrm{F}$ & $\mathrm{b}$ & & & & zomer \\
\hline & & Aalscholver & & & $\mathrm{R}$ & & & jaarrond \\
\hline & \multirow{8}{*}{$\begin{array}{c}1.11 \text { Rust en } \\
\text { foerageergebieden }\end{array}$} & \multirow{8}{*}{$\begin{array}{l}\text { Steenloper } \\
\text { Rosse grutto } \\
\text { Bonte strandloper } \\
\text { Kanoet } \\
\text { Scholekster } \\
\text { Eider } \\
\text { Gewone zeehond } \\
\text { Grijze zeehond } \\
\end{array}$} & & & $\mathrm{R}$ & & & winter \\
\hline & & & & & $\mathrm{R}$ & & & winter \\
\hline & & & & & $\mathrm{R}$ & & & winter \\
\hline & & & & & $\mathrm{R}$ & & & winter \\
\hline & & & & & $\mathrm{R}$ & & & jaarrond \\
\hline & & & & & $\mathrm{R}$ & & & jaarrond \\
\hline & & & & & $\mathrm{R}$ & $\mathrm{V}$ & & jaarrond \\
\hline & & & & & $\mathrm{R}$ & $\mathrm{V}$ & & jaarrond \\
\hline \multirow{14}{*}{$\begin{array}{c}\text { H1310A\&B; H1330A } \\
\text { Zilte pionierbegroeiingen; } \\
\text { Schorren en zilte } \\
\text { graslanden }\end{array}$} & & Bergeend* & & & $\mathrm{R}$ & & & jaarrond \\
\hline & & Steenloper & & & $\mathrm{R}$ & & & winter \\
\hline & & Bonte strandloper & & & $\mathrm{R}$ & & & winter \\
\hline & & Drieteenstrandloper & & & $\mathrm{R}$ & & & winter \\
\hline & & Rosse grutto & & & $\mathrm{R}$ & & & winter \\
\hline & & Strandplevier & & & $\mathrm{R}$ & B & & zomer \\
\hline & & Wulp & & & $\mathrm{R}$ & & & jaarrond \\
\hline & & Zilverplevier & & & $\mathrm{R}$ & & & winter \\
\hline & & Aalscholver & & & $\mathrm{R}$ & & & jaarrond \\
\hline & & Dwergstern & & & $\mathrm{R}$ & B & & zomer \\
\hline & & Gewone zeehond & & & $\mathrm{R}$ & & & jaarrond \\
\hline & \multirow{6}{*}{$\begin{array}{c}1.13 \text { Voortplantings } \\
\text { habitat }\end{array}$} & Grijze zeehond & & & $\mathrm{R}$ & & & jaarrond \\
\hline & & Bontbekplevier & & & $\mathrm{R}$ & B & & jaarrond \\
\hline & & Kluut* & & & $\mathrm{R}$ & & & jaarrond \\
\hline$\underline{\mathrm{H} 2110}$ & & Bontbekplevier & & & & $B$ & & zomer \\
\hline Embryonale wandelende & & Strandplevier** & & & & B & & zomer \\
\hline duinen & & Dwergstern & & & & B & & zomer \\
\hline $\begin{array}{c}\mathrm{H} 2190 \\
\text { Vochtige duinvalleien, } \\
\text { kalkrijk }\end{array}$ & & & & & & & & \\
\hline
\end{tabular}

* Bergeend en kluut Typische soorten van H1330A; ** strandplevier Typische soort van $\mathrm{H} 2110$;

*** Met bodems van verschillende ouderdom en meer natuurlijke opbouw van vispopulaties. 


\subsection{Ruimtelijke aanwezigheid}

De ruimtelijke verspreiding van habitattypen, habitatsoorten en vogelsoorten in het studiegebied is al beschreven in paragraaf 4.1.2, gebaseerd op de beschrijvingen en verspreidingskaarten in Jak et al. (2014b), het beheerplan voor de Noordzeekustzone (Ministerie van Infrastructuur en Milieu, 2016a) en dat van Texel (Rijksdienst voor Ondernemend Nederland, 2016), waarin meer detailinformatie is te vinden.

De verspreiding en dichtheid van een aantal soorten vogels en zeezoogdieren en schelpdieren in de kustzone wordt regelmatig gemonitord in opdracht van de Nederlandse overheid. Wij hebben daarom gericht gezocht naar recentere informatie over monitoringsgegevens voor de ruimtelijke verspreiding van een aantal relevante soorten in en rond het studiegebied.

Aarts et al. (2018) en Brasseur et al. (2019) vonden dat zeehonden vaak voor de kust van Texel komen. Dat zal betekenen dat ze ook gebruik maken van het onderhavige studiegebied.

De dichtheden van bruinvissen worden gemonitord (o.a. Geelhoed et al., 2020), maar niet zo fijnschalig dat daar gedetailleerde informatie over de bruinvis in het studiegebied uit kan worden gehaald. Maar we kunnen er wel vanuit gaan dat de bruinvis er wel kan voorkomen. Dit wordt bevestigd door waarnemingen van zeetrektellers (www.trektellen. $\mathrm{nl}$ ).

Het voorkomen van de talrijkste soorten zeevogels en de bruinvis wordt op het Nederlands Continentaal Plat (NCP) gemonitord en is door Fijn et al. (2019) gerapporteerd voor de periode augustus 2018 tot juni 2019. Daartoe behoren de voor de Noordzeekustzone relevante soorten roodkeelduiker, aalscholver, zwarte zee-eend, dwergmeeuw, bruinvis, grijze zeehond en gewone zeehond.

De zwarte zee-eend is vaker geteld in de kustzone, o.a. door Leopold et al. (2013) en veel verspreidingskaarten zijn te vinden in Kleijberg et al. (2019). De zwarte zee-eend komt niet zo vaak voor de kust van Texel. In enkele jaren is de zwarte zee-eend toch wel in het gebied waargenomen en dan soms in grote aantallen (tienduizenden), zoals gerapporteerd door Leopold et al. (2015) en Fijn et al. (2017). De winterverspreiding van Zwarte Zee-eenden in Nederland concentreerde zich in de afgelopen jaren ten noorden van de oostelijke Waddeneilanden en in mindere mate in de Voordelta. In sommige jaren verblijven echter grote groepen op andere plaatsen. In het voorjaar van 2013 en 2014 doken ineens grote aantallen Zwarte Zee-eenden op voor de kust van Texel (Fijn et al., 2017). Dit heeft waarschijnlijk te maken met de grote dichtheid aanwezige voedsel in de zeebodem aldaar.

\subsection{Mogelijk optreden van effecten op habitattypen, soorten en hun instandhoudingsdoelstellingen}

In deze paragraaf volgt een beschrijving van de (mogelijke) effecten per soortgroep en individuele natuurwaarden.

\subsubsection{Habitattypen}

Van de zeven habitattypen van de Noordzeekustzone komen er vijf (H1310A, H1310B, H1330A, $\mathrm{H} 2110, \mathrm{H} 2190 \mathrm{~B}$ ) niet voor in het studiegebied. Significante gevolgen voor de instandhoudingsdoelstellingen van deze habitattypen kunnen daarom worden uitgesloten.

Habitattype slik- en zandplaten (H1140B) komt wel voor in het studiegebied, namelijk op het strand bij paal19/20, waar het waarschijnlijk gaat om een strook van enkele tientallen meters breed. Er zijn niet veel organismen in de bodem te vinden, behalve aanspoelsels en wat strandvlooien en (gemshoorn)wormen die als voedsel voor steltlopers kunnen dienen. Er valt een tijdelijk negatief effect te verwachten op de kwaliteit van het habitattype door het ingraven van de kabel. Door de grote dynamiek van het systeem zal naar verwachting een spoedig herstel optreden nadat de kabel is 
ingegraven. Effecten kunnen niet op voorhand worden uitgesloten, maar zullen waarschijnlijk klein en tijdelijk van aard zijn. Significante gevolgen voor de instandhoudingsdoelstellingen van H1140B worden uitgesloten.

Permanent overstroomde zandbanken (H1110B) komen voor in een groot deel van het studiegebied. $\mathrm{Er}$ is een potentieel negatief effect van de voorgenomen activiteit op dit habitattype door verandering golfslag, verandering dynamiek substraat, vertroebeling, verontreiniging en introductie hard substraat (positief). Een potentieel significant gevolg van deze verstoringsfactoren voor de instandhoudingsdoelstelling van $\mathrm{H} 1110 \mathrm{~B}$ is uit te sluiten omdat het veranderde oppervlak van $\mathrm{H} 1110 \mathrm{~B}$ naar verwachting minder dan 10 ha is. $\mathrm{Er}$ is een potentieel positief effect op de biodiversiteit te verwachten waar zich het Slow Mill-anker bevindt.

\subsubsection{Habitatrichtlijnsoorten}

\subsubsection{Trekvissen}

De drie trekvissoorten zeeprik, rivierprik en fint komen waarschijnlijk voor in het studiegebied omdat de hele Noordzeekustzone behoort tot hun leefgebied. Er is een potentieel negatief effect van de_Slow Mill-pilotinstallatie op deze soorten door verwonding en of dood door botsing of verstrikking en verstoring door geluid onder water. Elektromagnetische straling kan effect hebben op zeeprik en rivierprik omdat kraakbeenvissen gevoeliger zijn dan beenvissen, zoals fint. Het is onbekend of deze drie trekvissoorten enig (positief of negatief) effect ondervinden van de introductie van hard substraat. Waarschijnlijk geen omdat deze soorten alleen trekken in het studiegebied, en zeeprik en rivierprik bovendien parasiteren.

Een potentieel gevolg voor instandhoudingsdoelstellingen van de drie soorten trekvissen hoeft niet op te treden, maar kan met de huidige kennis niet worden uitgesloten. De verbeterdoelstelling ligt op het verbeteren van de zout-zoet-barrière. De Slow Mill-activiteit brengt de verbetering niet in gevaar. Het zou echter wel kunnen dat er voor deze vissen een barrière ontstaat door de kabel. Bovendien, moet de sterfte in een bepaalde periode worden ingeschat en worden aangegeven in relatie tot het aantal individuen van de populatie waarover het gaat. Potentieel negatieve effecten op de drie vissoorten en hun instandhoudingsdoelstelling kunnen niet op voorhand worden uitgesloten.

De overige aandachtsoorten onder de vissen zijn elft, houting, steur en zalm (paragraaf 4.3 en bijlage 5). Over de verspreiding en de bijbehorende aantallen van deze soorten in het studiegebied is zeer weinig bekend. We nemen aan dat ze wel in het studiegebied voorkomen. Elft, houting en zalm zijn wat gevoeligheid voor een Slow Mill-pilotinstallatie betreft waarschijnlijk redelijk vergelijkbaar met de fint. De steur is een kraakbeenvis en daarom relatief gevoelig voor elektromagnetische straling van elektriciteitskabels en bovendien foerageert de steur op benthos en daardoor dichtbij de zeebodem. We nemen daarom aan dat potentieel negatieve effecten van de Slow Mill-pilotinstallaties op de elft, houting, steur en zalm en hun populaties niet op voorhand kunnen worden uitgesloten.

\subsubsection{Zeezoogdieren}

Gewone zeehonden, grijze zeehonden en bruinvissen maken regelmatig gebruik van het studiegebied. De Slow Mill-pilotinstallatie kan een potentieel negatief effect hebben door de verstoringsfactoren verwonding en/of dood door botsing en verstrikking, verstoring door geluid en elektromagnetische straling. Zeehonden zouden mogelijk wel kunnen profiteren van een hoger voedselaanbod bij de Slow Mill-installatie. Bruinvissen zullen waarschijnlijk niet van profiteren omdat ze waarschijnlijk afstand zullen houden tot de Slow Mill-installatie.

Een potentieel negatief effect voor instandhoudingsdoelstellingen van deze drie soorten zoogdieren is niet uit te sluiten. Hierbij speelt mee dat er kennislacunes zijn betreffende de gevoeligheid voor botsingen en verstrikkingen met WECs in het algemeen en met de Slow Mill-pilotinstallatie in het bijzonder, en de geluidsniveaus die worden geproduceerd door de Slow Mill-pilotinstallatie.

De overige aandachtsoorten onder de zeezoogdieren in het studiegebied zijn laatvlieger, gewone dwergvleermuis, noordse vleermuis, rosse vleermuis, ruige dwergvleermuis, tweekleurige vleermuis. (paragraaf 4.3 en bijlage 5). Deze soorten verblijven alleen boven zee tijdens de zomer om er te 
foerageren en tijdens de doortrek. Vleermuizen zullen niet worden aangetrokken tot WECs zoals de Slow Mill-pilotinstallatie omdat deze amper boven het zeeoppervlak uitkomt. Vleermuizen zullen niet op de installaties gaan rusten, en botsingen en andere effecten worden daarom uitgesloten (Sander Lagerveld (WMR), pers. med.).

\subsubsection{Vogels}

Broedvogels: De bontbekplevier, strandplevier en dwergstern komen in het studiegebied niet voor als broedvogels. Dit kan ook te maken hebben met de intensieve recreatie in en rond het plangebied en in het studiegebied. Deze soorten zullen daarom niet worden blootgesteld aan verstoring die wordt veroorzaakt door de werkzaamheden voor het ingraven van de kabel van de Slow Mill-pilotinstallatie. Significante gevolgen voor de instandhoudingsdoelstellingen van deze soorten kunnen worden uitgesloten.

Niet-broedvogels: Onder de niet-broedvogelsoorten zijn er twaalf soorten die in relatief lage aantallen voorkomen in het studiegebied: bergeend, topper, scholekster, kluut, bontbekplevier, zilverplevier, kanoet, drieteenstrandloper, bonte strandloper, rosse grutto, wulp en steenloper. Het studiegebied is van geringe tot marginale betekenis voor deze soorten. Het effect van de tijdelijke verstoring door bovenwatergeluid of optische verstoring door aanwezigheid van mensen, schepen en materieel is verwaarloosbaar. Negatieve gevolgen voor de instandhoudingsdoelstellingen van deze soorten worden dan ook uitgesloten.

De roodkeelduiker, parelduiker, aalscholver, eidereend, zwarte zee-eend en dwergmeeuw komen op open water voor, ook in het studiegebied. De dwergmeeuw pikt voedsel op van het wateroppervlak, waardoor sterfte of verwonding door botsing met de onderwater delen van de Slow Mill-pilotinstallatie niet op zal treden. De andere vijf soorten duiken diep naar voedsel (vis of schelpdieren) en kunnen wel botsen met de (bewegende) onderwaterdelen van de Slow Mill-pilotinstallatie. Overige verstoringsfactoren die mogelijk effecten veroorzaken op alle zes vogelsoorten zijn optische verstoring (ontwijking), verstoring door geluid (boven water), verandering golfslag, introductie hard substraat (positief). Vanwege de genoemde potentiële negatieve effecten kunnen negatieve gevolgen voor de instandhoudingsdoelstellingen van deze zes niet-broedvogelsoorten niet worden uitgesloten. 


\section{Stikstofdepositie}

Er is de laatste jaren in veel Natura 2000-gebieden een overschot aan stikstof (in de vorm van ammonium en nitraat door depositie van ammoniak en stikstofoxiden) en dit is schadelijk voor de natuur. Het belemmert ook de vergunningverlening voor economische activiteiten.

Het huidige stikstofbeleid steunt op twee pijlers om de natuurdoelen van Natura 2000 zeker te stellen:

- $\quad$ het blijvend laten dalen van de stikstofdepositie door het nemen van maatregelen aan de bron;

- $\quad$ het uitvoeren van herstelmaatregelen voor stikstofgevoelige natuur.

De aanleg en het onderhoud van de Slow Mill-pilotinstallatie op zee veroorzaakt (tijdelijk) een emissie van stikstofoxiden. Schepen en graafmachines die worden ingezet maken gebruik van verbrandingsmotoren die (ook) stikstofoxiden uitstoten. Derhalve wordt in deze voortoets ook ingegaan op het effect van stikstofdepositie als gevolg van de aanleg en het onderhoud van de installatie.

De geplande activiteiten zijn te verdelen in een bouwfase, een operationele fase en een ontmantelingsfase. Per fase is de stikstofdepositie berekend met de AERIUS Calculator 2019A (releasedatum 14 januari 2020). Het betreft vooral scheepsbewegingen van en naar de locatie van de Slow Mill-pilotinstallatie en ook graafwerkzaamheden bij het strand (zie tabel 1).

De AERIUS Calculator (https://calculator.aerius.nl/calculator/) berekent de stikstofuitstoot voor verschillende menselijke activiteiten. Een AERIUS-berekening is uitgevoerd voor de categorie sleepboten met een bruto tonnage van 100-1599. De gebruikte schepen vallen daarmee in de klasse met het laagste interne volume. De schepen die voor de werkzaamheden voor de Slow Millpilotinstallatie ingezet worden zijn dus relatief klein.

\section{Bouwfase}

In figuur 12 zijn de verschillende vaarroutes weergegeven die voor de berekening van de stikstofdepositie zijn toegepast op de activiteiten in de opbouwfase. De bouwwerkzaamheden, inclusief inregeling van de installatie, vinden binnen één jaar plaats (in 2021). Het gaat om:

1. De vaarroute van MV RAM van de locatie van de Slow Mill naar de kust, voor de aanleg van de kabel. Een worst case-situatie is gekozen, waarbij het traject tijdens drie dagen heen en weer wordt afgelegd, in totaal dus zes maal. De berekende NOx-emissie hierbij is $14,49 \mathrm{~kg} / \mathrm{j}$.

2. De vaarroute van MV RAM vanuit de haven van Den Helder naar de locatie van de Slow Mill. Hierbij is uitgegaan van drie vaarbewegingen naar en van de locatie. De afstand wordt dus zes maal afgelegd. De berekende NOx-emissie is hierbij 134,45 kg/jaar.

3. De vaarroute van de Empiric van de haven van Den Helder naar de locatie van de Slow Mill. Het gaat in totaal om 36 vaarbewegingen van en naar de locatie, voor het brengen van het anker en de Slow Mill, en voor diverse transporten ten behoeve van montage, onderhoud en testwerkzaamheden. In totaal wordt de afstand dus 72 maal afgelegd. De berekende NOxemissie hierbij is $931,25 \mathrm{~kg} / \mathrm{jaar}$.

4. Graafwerkzaamheden met een graafmachine bij de eerste duinenrij gedurende drie dagen met een graafmachine met een vermogen van $200 \mathrm{~kW}$. De berekende NOx-emissie hierbij is 8,35 $\mathrm{kg} / \mathrm{jaar}$.

De stikstofdepositie vindt plaats in drie relevante, stikstofgevoelige (cf. AERIUS Calculator) Natura 2000-gebieden. De hoogste berekende bijdrage van stikstof is $0,07 \mathrm{~mol} / \mathrm{ha} / \mathrm{j}$ (mol stikstof per hectare per jaar) in Duinen en Lage Land Texel, en $0,01 \mathrm{~mol} / \mathrm{ha} / \mathrm{j}$ in de Waddenzee en $0,01 \mathrm{~mol} / \mathrm{ha} / \mathrm{j}$ in de Duinen Den Helder-Callantsoog. De rekenresultaten van de AERIUS Calculator voor de opbouwfase staan in meer detail in bijlage 6 .

\section{Operationele fase}

Voor de werkzaamheden gedurende de operationele fase is uitgegaan van dertig vaarbewegingen per jaar (zie tabel 1), via route 2 zoals aangegeven in figuur 12. De totale NOx-uitstoot is $370,37 \mathrm{~kg} / \mathrm{jaar}$. Voor de Duinen en Lage Land Texel levert dit een hoogste bijdrage van $0,01 \mathrm{~mol} / \mathrm{ha} / \mathrm{j}$ voor alle 
habitattypen. Voor Natura 2000-gebied Waddenzee en Duinen Den Helder-Callantsoog blijkt de depositie verwaarloosbaar.

\section{Ontmantelingsfase}

In de ontmantelingsfase worden in vier vaarbewegingen uitgevoerd voor het verwijderen van het anker en de Slow Mill (tabel 1). Daarnaast wordt twee keer gevaren voor het verwijderen van de kabel uit de zeebodem. Ook wordt in een dag de kabel uit strand en duin verwijderd met een graafmachine.

De hoogste stikstofbijdrage betreft de depositie van 0,02 mol/ha/j voor de Duinen en Lage Land Texel. Deze hoogste bijdrage betreft H2130 B Grijze duinen (kalkarm), H2160 Duindoornstruwelen, H1330A Schorren en zilte graslanden (buitendijks) en H2130A Grijze duinen (kalkrijk). Voor de overige habitattypen is de bijdrage $0,1 \mathrm{~mol} / \mathrm{ha} / \mathrm{j}$.

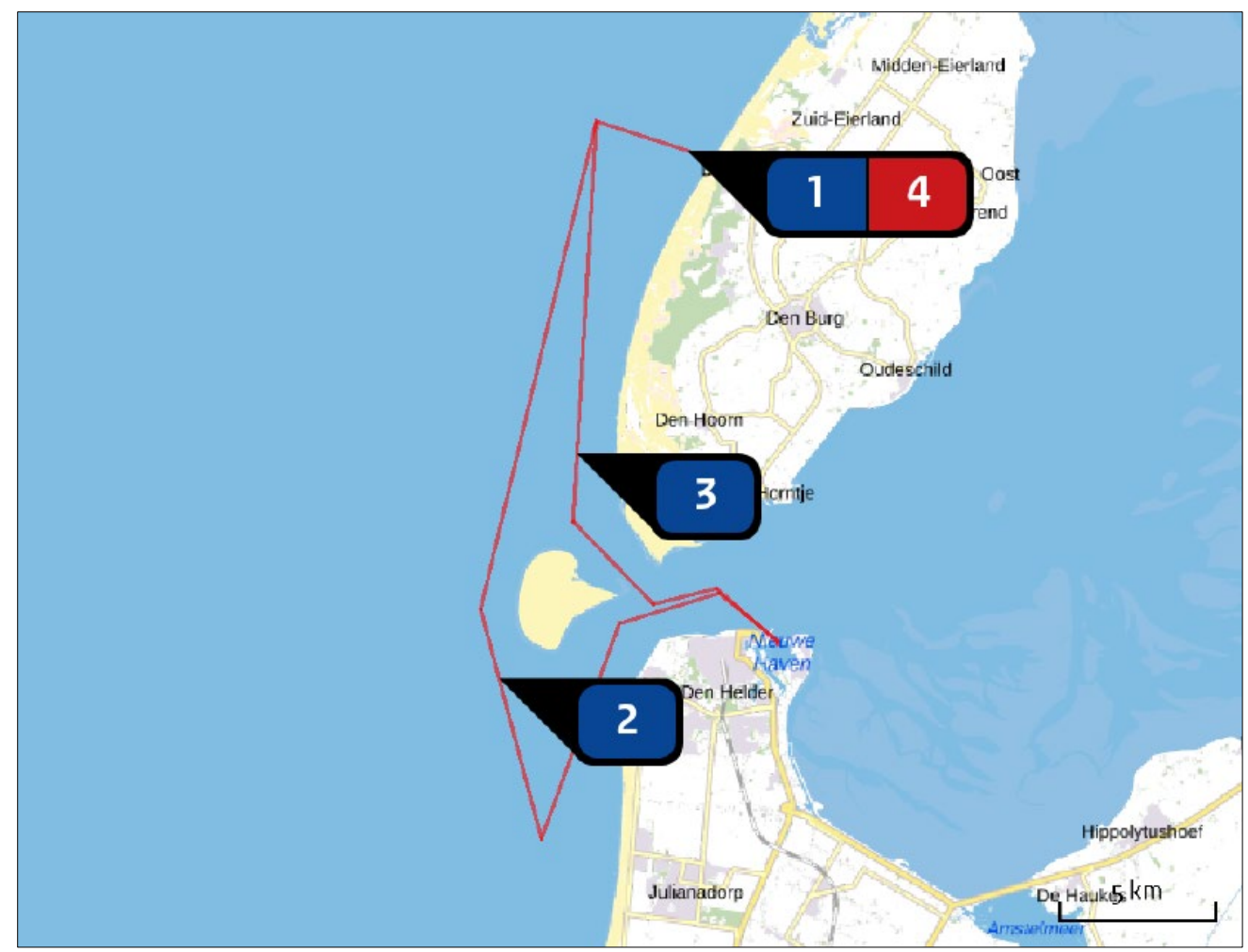

Figuur 12 Vaarroutes (1, 2 en 3 ) en graafwerkzaamheden (4) die gebruikt zijn voor de berekening van de uitstoot en depositie van stikstof in Natura 2000-gebieden

De totale uitstoot van de voorgenomen activiteiten van het Slow Mill-pilotproject op de relevante stikstofgevoelige Natura 2000-gebieden is in het jaar van de bouw 1,09 ton, in de operationele fase 0,37 ton per jaar en in het jaar van ontmanteling 0,08 ton. Over de duur van het gehele project (vijf jaar) is de totale berekende uitstoot 2,65 ton.

Voor de Duinen en Lage Land van Texel levert dit een hoogste bijdrage op van 0,07 mol/ha/j. Voor de Natura 2000-gebieden Waddenzee en Duinen Den Helder-Callantsoog is de hoogste bijdrage 0,01 $\mathrm{mol} / \mathrm{ha} / \mathrm{j}$.

Een normtoetsing vindt uitsluitend door het bevoegd gezag plaats. 


\section{Conclusies}

De voorgenomen activiteiten voor de Slow Mill-pilotinstallatie in de verschillende fases zijn geanalyseerd wat betreft hun effecten op de Natura 2000-instandhoudingsdoelstellingen van habitats en soorten. Dat is gedaan op basis van de beschikbare kennis en informatie. Echter doordat installaties zoals de Slow Mill-pilotinstallatie nog volop in ontwikkeling zijn, met een beperkt aantal kleine toepassingen, zijn er nog veel onzekerheden omtrent het optreden van effecten, wat noopt tot een voorzichtige benadering waar, zoals hier voor de voortoets, met zekerheid kunnen uitsluiten gevraagd is.

Wat betreft het Natura 2000-gebied Noordzeekustzone worden significante gevolgen van de Slow Millpilotinstallatie uitgesloten voor de volgende instandhoudingsdoelen:

- zeven habitattypen (H1110B, H1140B, H1310A, H1310B, H1330A, H2110, H2190B);

- drie broedvogelsoorten (bontbekplevier, strandplevier en dwergstern);

- twaalf niet-broedvogelsoorten (bergeend, topper, scholekster, kluut, bontbekplevier, zilverplevier, kanoet, drieteenstrandloper, bonte strandloper, rosse grutto, wulp en steenloper).

en kunnen significante gevolgen niet op voorhand worden uitgesloten voor:

- drie trekvissoorten (zeeprik, rivierprik en fint);

- drie zeezoogdiersoorten (gewone zeehond, grijze zeehond, bruinvis);

- $\quad$ zes niet-broedvogelsoorten (roodkeelduiker, parelduiker, aalscholver, eidereend, zwarte zeeeend en dwergmeeuw).

Vanwege de bescherming van overige soorten (voorkomend op bijlage IV van de habitatrichtlijn, bijlage II van Bern en/of bijlage I van Bonn) die bovendien bekend zijn als regelmatige gast of regelmatige voortplanter op het NCP en waarschijnlijk ook in het studiegebied kunnen voorkomen, is eveneens getoetst op de eventuele effecten van de Slow Mill-pilotinstallatie. De conclusies zijn dat:

- $\quad$ effecten worden uitgesloten voor vijf vleermuissoorten (laatvlieger, gewone dwergvleermuis, noordse vleermuis, rosse vleermuis, ruige dwergvleermuis);

- $\quad$ potentieel negatieve effecten niet uitgesloten worden voor vier vissoorten (elft, houting, steur, zalm) en hun populaties.

Er worden geen effecten op habitattypen en soorten van het Natura 2000-gebied Duinen en Lage Land Texel verwacht omdat de projectactiviteiten zich bevinden buiten de begrenzing van dat gebied en geen externe werking van verstorende projectactiviteiten wordt verwacht. Een uitzondering wordt gemaakt voor de kleine mantelmeeuw van de broedkolonies op Texel, die ook foerageert voor de kust van De Koog.

De stikstofberekeningen zijn gedaan met de AERIUS Calculator. Een normtoetsing voor wat betreft de stikstofemissies is voorbehouden aan het bevoegd gezag. Daarom wordt hier geen conclusie voor stikstof opgenomen. 


\section{Kwaliteitsborging}

Wageningen Marine Research beschikt over een ISO 9001:2015 gecertificeerd kwaliteitsmanagementsysteem. Dit certificaat is geldig tot 15 december 2021. De organisatie is gecertificeerd sinds 27 februari 2001. De certificering is uitgevoerd door DNV GL. 


\section{Literatuur}

Aarts, G., J. Cremer, R. Kirkwood, J.T. van der Wal, J. Matthiopoulos \& S. Brasseur (2016). Spatial distribution and habitat preference of harbour seals (Phoca vitulina) in the Dutch North Sea. Wageningen University \& Research centre, Wageningen Marine Research, Wageningen Marine Research report number C118/16, 43 pageshttp://dx.doi.org/10.18174/400306

Baptist, M., M.F. Leopold (2018). Pilotstudie GPS-trackers grote sterns van Utopia, Texel 2018 Wageningen University \& Research report C095/18. Wageningen Marine Research, Den Helder.

Besluit Milieueffectrapportage, geldend van 01-07-2018 t/m heden.

https://wetten.overheid.nl/BWBR0006788/2018-07-01 [laatst geraadpleegd: augustus 2020]

Boshamer J.P.C. \& J.P. Bekker (2008). Nathusius' pipistrelles (Pipistrellus nathusii) and other species of bats on offshore platforms in the Dutch sector of the North Sea. Lutra 200851 (1): 17-36.

Brasseur, S., Schop, J., Cremer, J. \& Aarts, G. (2019). Harbour seal monitoring and evaluation for the Luchterduinen offshore windfarm. doi:10.18174/461959

Buscaino, G., G. Mattiazzo, G. Sannino, E. Papale, G. Bracco, R. Grammauta, A. Carillo, J.M. Kenny, N. De Cristofaro, M. Ceraulo \& S. Mazzola (2019). Acoustic impact of a wave energy converter in Mediterranean shallow waters. Scientific Reports volume 9, Article number: 9586 (2019).

Contardo, S. (2018). In situ observations and simulations of coastal wave field transformation by wave energy converters. Coastal Engineering. 140: 175-188.

Copping, A., H. Battey, J. Brown-Saracino, M. Massaua, C. Smith (2014). An international assessment of the environmental effects of marine energy development. Ocean \& Coastal Management 99 (2014) $3 e 13$.

Copping, A. \& Hemery, L. (2020). OES-Environmental 2020 State of the Science Report:

Environmental Effects of Marine Renewable Energy Development Around the World. Report for Ocean Energy Systems (OES).

De Jong M.L., C.J. Smit \& M.F. Leopold (2010). Aantallen en verspreiding van eiders, toppers en zeeeenden in de winter van 2009-2010 in de Waddenzee en de Noordzeekustzone, Den Burg. Imares Rapport C160/10.

Fijn, R.C., F.A. Arts, J.W. de Jong, D. Beuker, E.L. Bravo Rebolledo, B.W.R. Engels, M. Hoekstein, RJ. Jonkvorst, S. Lilipaly, M. Sluijter, K.D. van Straalen \& P.A. Wolf (2019). Verspreiding, abundantie en trends van zeevogels en zeezoogdieren op het Nederlands Continentaal Plat in 2018-2019. RWSCentrale Informatievoorziening BM 19.23. Bureau Waardenburg Rapportnr. 19-258. Bureau Waardenburg \& Deltamilieu Projecten, Culemborg.

Fijn, R.C., Leopold, M.F., Dirksen, S., Arts, F., Asch, M. van; Baptist, M.J.; Craeymeersch, J.A.M. ; Engels, B., Horssen, P. van, Jong, J. de; Perdon, K.J., Zee, E.M. van der, Ham, N. (2017). Een onverwachte concentratie van Zwarte Zee-eenden in de Hollandse kustzone in een gebied met hoge dichtheden van geschikte schelpdieren. Limosa 90 (2017)3. - ISSN 0024-3620 - p. 97 - 117.

Furness, R.W., Wade, H.M., Robbins, A.M.C. \& Masden, E.A. (2012). Assessing the sensitivity of seabird populations to adverse effects from tidal stream turbines and wave energy devices ICES Journal of Marine Science. doi.org/10.1093/icesjms/fss131

Geelhoed, S., Janinhoff, N., Lagerveld, S., \& Verdaat, H. (2020). Marine mammal surveys in Dutch North Sea waters in 2019. doi:10.18174/515228 
Grecian, W.J., R. Inger, M.J. Attrill, S. Bearshop, B.J. Godley, M.J. Witt \& S.C. Votier (2010). Potential impacts of wave-powered marine renewable energy installations on marine birds. Ibis (2010), 152, 683-697.

Haikonen, K., J. Sundberg \& M. Leijon (2013). Characteristics of the Operational Noise from Full Scale Wave Energy Converters in the Lysekil Project: Estimation of Potential Environmental Impacts. Energies 2013, 6, 2562-2582; doi:10.3390/en6052562.

Jak, R., van Bemmelen, R., van Duin, W., Geelhoed, S., \& Tamis, J. (2014a). Natura 2000-doelen in de Noordzeekustzone. Van doelen naar opgaven voor natuurbescherming. Wageningen Marine Research. Rapport C050/11a.

Jak, R., van Bemmelen, R., van Duin, W., Geelhoed, S., \& Tamis, J. (2014b). Natura 2000-doelen in de Noordzeekustzone. Van doelen naar opgaven voor natuurbescherming. Bijlagerapport.

Wageningen. Marine Research. Rapport C123/14.

Jongbloed R.H., J.T. van der Wal, J.E. Tamis, R.G. Jak, S.I. Jonker, B.J.H. Koolstra \& J.H.M. Schobben (2011). Nadere effectenanalyse Natura 2000-gebieden Waddenzee en Noordzeekustzone. Niet Nbwetvergund gebruik. IMARES rapport C170/11, ARCADIS rapport 057990726:B

Jonge Poerink B., S. Lagerveld, H. Verdaat (2013). Pilot study, Bat activity in the Dutch offshore wind farm, OWEZ and PAWP. IMARES report number C026/13 / tFC report number 20120402.

Kleijberg, R., M.J.C. Rozemeijer \& J.T. van der Wal (2019). Zandwinning Noordzee 2018-2027. Nadere verdieping effecten Natura 2000 - Actualisatie 2019. Arcadis rapport.

Krijgsveld K.L., Smits R.R. \& van der Winden J. (2008). Verstoringsgevoeligheid van vogels. Update literatuurstudie naar de reacties van vogels op recreatie. Bureau Waardenburg/Vogelbescherming Nederland rapport nr. 08-173.

Krol, J. (2010). Aantallen strandbroeders in de Nederlandse Waddenzee. Rapportage t/m broedseizoen 2008. Natuurcentrum Ameland.

Lagerveld, S., van der Wal, J. T., Vries, V., Verdaat, H., Sonneveld, C., van der Meer, J., Brabant, R. \& Noort, B., 2019, Bats at the southern North Sea in 2017 \& 2018. Den Helder: Wageningen Marine Research. 36 p. (Wageningen Marine Research report ; C062/19)

Langhamer, O. (2010). Effects of wave energy converters on the surrounding soft-bottom macrofauna (west coast of Sweden). Marine Environmental Research. Volume 69, Issue 5, June 2010, Pages 374381.

Lees, K.J., A.J. Guerin \& E.A. Masden (2016). Using kernel density estimation to marine renewable wave energy test facility. Marine Policy 63 (2016) 35-44.

Leopold, M., R. van Bemmelen, J. Perdon, M. Poot, C. Heunks, D. Beuker, R. Jonkvorst \& J. de Jong (2013). Zwarte Zee-eenden in de Noordzeekustzone benoorden de Wadden: verspreiding en aantallen in relatie tot voedsel en verstoring. IMARES Wageningen UR, Rapport C023/13.

Leopold, M., M. van Asch, E. Dijkman, K. Goudswaard, S. Lagerveld, H. Verdaat, K. Camphuysen \& J. ten Horn (2015). Zwarte zee-eenden bij Texel, een reactie op overvloedig voorkomen van Ensis? IMARES Wageningen UR, Rapport C084/14.

Ministerie van ELI (2010). Wijzigingsbesluit Natura 2000-gebied Noordzeekustzone. Directie Regionale Zaken.

Ministerie van Infrastructuur en Milieu (2016a). Natura 2000-beheerplan Noordzeekustzone. Periode 2016-2022. Ministerie van Infrastructuur en Milieu.

Ministerie van Infrastructuur en Milieu (2016b). Kaartenbijlage Natura-2000 beheerplan Noordzeekustzone. 
Ministerie van LNV (2008). Aanwijzingsbesluit Natura 2000-gebied Duinen en Lage Tand Texel. Directie Regionale Zaken DRZO/2008-002.

Nall, C.R., M-L. Schläppy \& A.J. Guerin (2017). Characterisation of the biofouling community on a floating wave energy device. Biofouling, 33:5, 379-396, DOI: 10.1080/08927014.2017.1317755.

O'Brien, N., Nash, S. \& Hartnett, M. (2015). Modelling the hydro-environmental impacts of tidal farms with the use of a two-way nested model Renewable Energies Offshore - 1st International Conference on Renewable Energies Offshore, RENEW 2014. doi.org/

Pondera Consult (2018). Passende Beoordeling Transformatiesysteem Op Zee Hollandse Kust Zuid. Rapport. Datum 17 mei 2018.

Probert, P.K. \& R. Mitchell (1983). Environmental implications of wave energy. Proposals for the Outer Hebrides and Moray Firth. Ocean Engng, Vol. 10, No 6, pp.459-469, 1983.

Rijksdienst voor Ondernemend Nederland (2016). Natura 2000-beheerplan Texel (2). Juni 2016. Definitief beheerplan.

SOVON en CBS (2005). Trend in vogels in het Nederlandse Natura 2000 netwerk, SOVONinformatierapport 2005/09, SOVON Vogelonderzoek Nederland, Beek-Ubbergen.

SOVON (2007). Watervogels i Nederland in 2005/2006. Waterdienst-rapport BM07.09, SOVONmonitoringrapport 2007/03.

Tomey-Bozo, N., A. Babarit, J. Murphy, V. Stratigaki, P. Troch, T. Lewis \& G. Thomas (2019). Wake effect assessment of a flap type wave energy converter farm under realistic environmental conditions by using a numerical coupling methodology. Coastal Engineering 143 (2019) 96-112.

Tougaard, J. (2015). Underwater Noise from a Wave Energy Converter Is Unlikely to Affect Marine Mammals. PLoS ONE 10(7): e0132391. doi:10.1371/ journal.pone.0132391

Van Keeken, O.A., H.J.L. Heessen \& H.V. Winter (2010). Bescherming zoutwatervissen, Rapport C170/10.

Vogels op Texel, jaaroverzicht 2019 (2020), Vogelwerkgroep Texel.

Wiersma, P. \& C.J. Smit (2009). Hoogwatervluchtplaatsen van Texel op de kaart. SOVON onderzoeksrapport', SOVON Vogelonderzoek Nederland, Beek Ubbergen.

Witbaard, R., R. Dekker \& L. Kleine-Schaars (2020). Biodiversiteit rondom de Slow Mill in 2019. NIOZ rapport 2020-02.

Witbaard, R. \& E. Wagemaakers (2020). Data rapport Abiotiek 2019 - Slow Mill locatie, Texelse kust. NIOZ rapport. Concept? Texel, 25 juni 2020.

Witt, M.J., E. V. Sheehan, S. Bearhop, A. C. Broderick, D. C. Conley, S. P. Cotterell, E. Crow, W. J. Grecian, C. Halsband, D. J. Hodgson, P. Hosegood, R. Inger, P. I. Miller, D. W. Sims, R. C. Thompson, K. Vanstaen, S. C. Votier, M. J. Attrill \& B. J. Godley (2012). Assessing wave energy effects on biodiversity: the Wave Hub experience Author(s): Source: Philosophical Transactions: Mathematical, Physical and Engineering Sciences, Vol. 370, No. 1959, The Peaks and troughs of wave energy: the dreams and the reality (28 January 2012), pp. 502-529. 


\section{Verantwoording}

Rapport C072/20

Projectnummer: 4315100142

Dit rapport is met grote zorgvuldigheid tot stand gekomen. De wetenschappelijke kwaliteit is intern getoetst door een collega-onderzoeker en het verantwoordelijk lid van het managementteam van Wageningen Marine Research

Akkoord: $\quad$ Dr Mardik Leopold i.v.m. afwezigheid Jakob Asjes

Onderzoeker

Handtekening:

Datum:

25 augustus 2020

Akkoord:

Drs Jakob Asjes

MT-lid Integratie

Handtekening:

Datum: 


\section{Bijlage 1 Instandhoudingsdoelstellingen Natura 2000-gebied Noordzee- kustzone}

Tabel 1 Instandhoudingsdoelstellingen van Natura 2000-gebied Noordzeekustzone. Aanwijzingsbesluit februari 2009 (Min. LNV, 2009)

\begin{tabular}{|c|c|c|c|c|}
\hline Instandhoudingsdoelstelling & 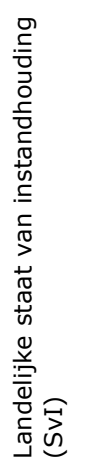 & 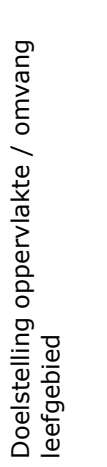 & 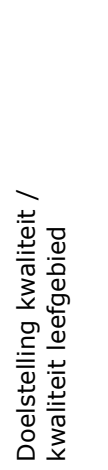 & 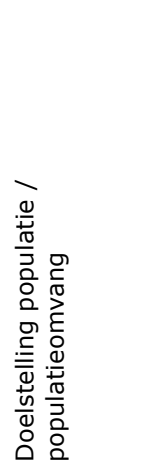 \\
\hline H1110B - Permanent overstroomde zandbanken & - & $=$ & $>$ & \\
\hline H1140B - Slik- en zandplaten & + & $=$ & $=$ & \\
\hline H1310A - Zilte pionierbegroeiingen (zeekraal) & - & $=$ & $=$ & \\
\hline H1310B - Zilte pionierbegroeiingen (zeevetmuur) & + & $=$ & $=$ & \\
\hline H1330A - Schorren en zilte graslanden (buitendijks) & - & $=$ & $=$ & \\
\hline H2110 - Embryonale duinen & + & $=$ & $=$ & \\
\hline H2190B - Vochtige duinvalleien (kalkrijk) & - & $=$ & $=$ & \\
\hline H1095 - Zeeprik & - & $=$ & $=$ & $>$ \\
\hline H1099 - Rivierprik & - & $=$ & $=$ & $>$ \\
\hline H1103 - Fint & -- & $=$ & $=$ & $>$ \\
\hline H1351 - Bruinvis & - & $=$ & $>$ & $=$ \\
\hline H1364 - Grijze zeehond & - & $=$ & $=$ & $=$ \\
\hline H1365 - Gewone zeehond & + & $=$ & $=$ & $=$ \\
\hline A137 - Bontbekplevier & - & $=$ & $=$ & 20 \\
\hline A138 - Strandplevier & -- & $>$ & $>$ & 30 \\
\hline A195 - Dwergstern & -- & $>$ & $>$ & 20 \\
\hline A001 - Roodkeelduiker & - & $=$ & $=$ & \\
\hline A002 - Parelduiker & $?$ & $=$ & $=$ & \\
\hline A017 - Aalscholver & + & $=$ & $=$ & 1900* \\
\hline A048 - Bergeend & + & $=$ & $=$ & 520* \\
\hline A062 - Topper & -- & $=$ & $=$ & \\
\hline A063 - Eider & -- & $=$ & $=$ & $26200 * *$ \\
\hline A065 - Zwarte zee-eend & - & $=$ & $=$ & $51900 * *$ \\
\hline A130 - Scholekster & -- & $=$ & $=$ & $3300 *$ \\
\hline A132 - Kluut & - & $=$ & $=$ & $120 *$ \\
\hline A137 - Bontbekplevier & + & $=$ & $=$ & $510^{*}$ \\
\hline A141 - Zilverplevier & + & $=$ & $=$ & $3200 *$ \\
\hline A143 - Kanoet & - & $=$ & $=$ & $560^{*}$ \\
\hline A144 - Drieteenstrandloper & - & $=$ & $=$ & 2000 \\
\hline A149 - Bonte strandloper & + & $=$ & $=$ & $7400 *$ \\
\hline A157 - Rosse grutto & + & $=$ & $=$ & $1800^{*}$ \\
\hline A160 - Wulp & + & $=$ & $=$ & $640 *$ \\
\hline A169 - Steenloper & -- & $=$ & $=$ & 160 \\
\hline A177 - Dwergmeeuw & - & $=$ & $=$ & \\
\hline
\end{tabular}




\begin{tabular}{|c|c|c|c|c|}
\hline Instandhoudingsdoelstelling & 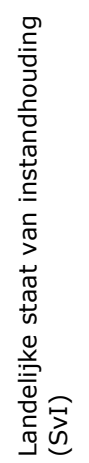 & 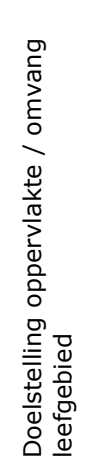 & 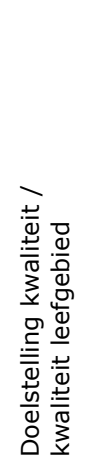 & 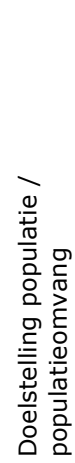 \\
\hline
\end{tabular}

\begin{tabular}{|l|l|l|l|l|l|}
\hline \multicolumn{2}{|l|}{ Legenda: } & \multicolumn{2}{l|}{ Doelstelling } & \multicolumn{2}{l|}{ Populatieomvang } \\
\hline Staat van instandhouding & $=$ & behoud & & $*$ & seizoensmaximum \\
\hline+ & gunstig & $>$ & Uitbreiding & $* *$ & $*$ midwinter aantallen \\
\hline- & matig gunstig & & & & \\
\hline-- & zeer ongunstig & & & & \\
\hline
\end{tabular}




\section{Bijlage 2 Instandhoudingsdoelstellingen Natura 2000-gebied Duinen en Lage Land Texel}

Tabel 1 Instandhoudingsdoelstellingen van Natura 2000-gebied Duinen en Lage Land Texel. Aanwijzingsbesluit februari 2009 (Ministerie van LNV, 2008).

\begin{tabular}{|c|c|c|c|c|}
\hline Instandhoudingsdoelstelling & 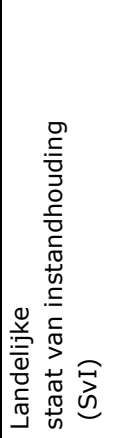 & 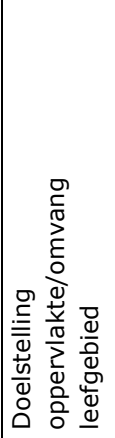 & 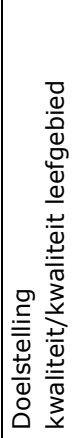 & 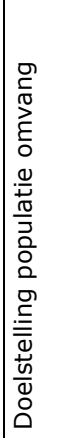 \\
\hline H1140A - Slik- en zandplaten (getijdengebied) & - & $=$ & $=$ & \\
\hline H1330A - Schorren en zilte graslanden (buitendijks) & - & $=$ & $=$ & \\
\hline H1330B - Schorren en zilte graslanden (binnendijks) & - & $=$ & $=$ & \\
\hline H2110 - Embryonale duinen & + & $=$ & $=$ & \\
\hline H2120 - Witte duinen & - & $=$ & $=$ & \\
\hline H2130A - *Grijze duinen (kalkrijk) & -- & $>$ & $>$ & \\
\hline H2130B - *Grijze duinen (kalkarm) & -- & $>$ & $>$ & \\
\hline H2130C - *Grijze duinen (heischraal) & -- & $>$ & $>$ & \\
\hline H2180B - Duinbossen (vochtig) & - & $=(<)$ & $>$ & \\
\hline H2180C - Duinbossen (binnenduinrand) & - & $=$ & $>$ & \\
\hline H2190A - Vochtige duinvalleien (open water) & - & $=$ & $>$ & \\
\hline H2190B - Vochtige duinvalleien (kalkrijk) & - & $=$ & $>$ & \\
\hline H2190C - Vochtige duinvalleien (ontkalkt) & - & $=$ & $>$ & \\
\hline H2190D - Vochtige duinvalleien (hoge moerasplanten) & - & $=$ & $>$ & \\
\hline H6230 - *Heischrale graslanden & -- & $=$ & $=$ & \\
\hline \multicolumn{5}{|l|}{ H6410 } \\
\hline H6430A - Ruigten en zomen (moerasspirea) & + & $=$ & $=$ & \\
\hline H6430B - Ruigten en zomen (harig wilgenroosje) & - & $=$ & $=$ & \\
\hline H6430C - Ruigten en zomen (droge bosranden) & - & $=$ & $=$ & \\
\hline H7210 - *Galigaanmoerassen & - & $=$ & $=$ & \\
\hline H1340 - *Noordse woelmuis & -- & $=$ & $>$ & $=$ \\
\hline H1364 - Grijze zeehond & - & $=$ & $=$ & $=$ \\
\hline H1903 - Groenknolorchis & -- & $=$ & $=$ & $=$ \\
\hline
\end{tabular}




\begin{tabular}{|c|c|c|c|c|}
\hline Instandhoudingsdoelstelling & 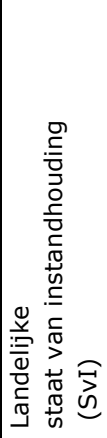 & 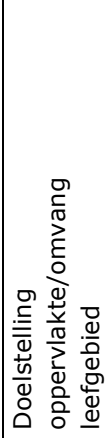 & 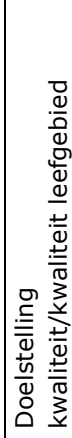 & 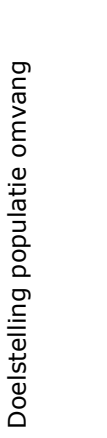 \\
\hline A034 - Lepelaar & + & $=$ & $=$ & 120 \\
\hline A063 - Eider & -- & $=$ & $=$ & 110 \\
\hline A081 - Bruine kiekendief & + & $=$ & $=$ & 30 \\
\hline A082 - Blauwe kiekendief & -- & $=$ & $=$ & 20 \\
\hline A132- Kluut & - & $=$ & $=$ & 120 \\
\hline A137 - Bontbekplevier & - & $>$ & $>$ & 20 \\
\hline \multicolumn{5}{|l|}{ A138 - Strandplevier } \\
\hline A183 - Kleine mantelmeeuw & + & $=$ & $=$ & 14000 \\
\hline A195 - Dwergstern & -- & $>$ & $>$ & 40 \\
\hline A222 - Velduil & -- & $>$ & $>$ & 20 \\
\hline A276 - Roodborsttapuit & + & $=$ & $=$ & 40 \\
\hline A277 - Tapuit & -- & $>$ & $>$ & 100 \\
\hline Legenda: zie tabel 1 Bijlage 1 & & & & \\
\hline
\end{tabular}




\section{Bijlage 3 Habitattypen van Natura 2000- gebieden Texel}

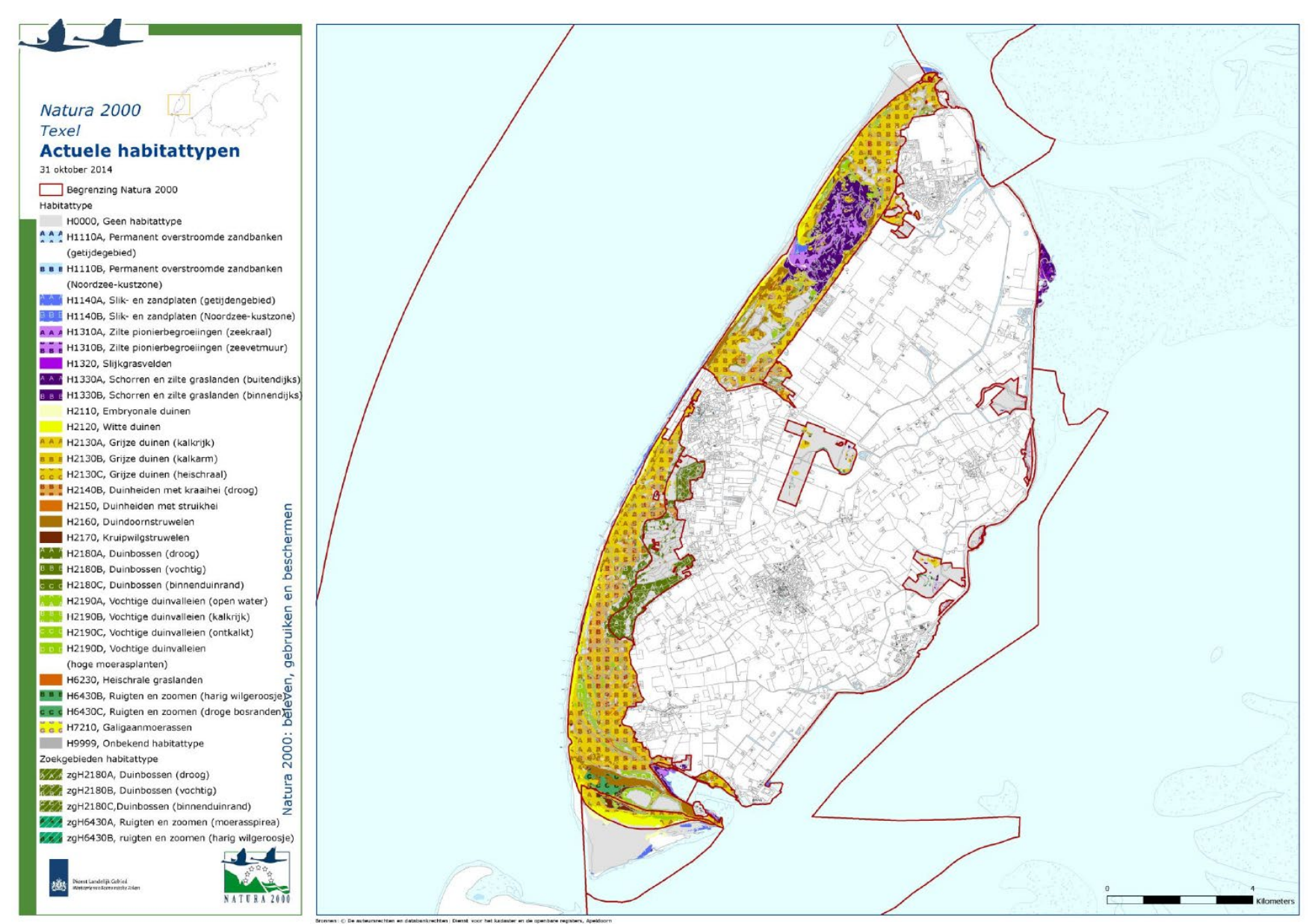

Figuur 1 Habitattypen Natura 2000-gebieden in en rondom Texel (Rijksdienst voor Ondernemend Nederland 2016. Natura 2000-beheerplan Texel (2). Juni 2016. Definitief beheerplan). 
Bijlage 4 Lijst van soorten die op bijlage IV van de habitatrichtlijn, bijlage II van Bern en/of bijlage I van Bonn staan 


\begin{tabular}{|c|c|c|c|c|c|c|}
\hline Nederlandse naam & Wetenschappelijke naam & Soortgroep & Habitatrichtlijn & Verdrag van Bern & Verdrag van Bonn & Vogelrichtlijn \\
\hline Boomkikker & Hyla arborea ssp. arborea & Amfibieën & Bijlage IV & Bijlage II & - & - \\
\hline Geelbuikvuurpad & Bombina variegata ssp. variegata & Amfibieën & Bijlage IV & Bijlage II & - & - \\
\hline Heikikker & Rana arvalis ssp. arvalis & Amfibieën & Bijlage IV & Bijlage II & - & - \\
\hline Kamsalamander & Triturus cristatus & Amfibieën & Bijlage IV & Bijlage II & - & E \\
\hline Knoflookpad & Pelobates fuscus ssp. fuscus & Amfibieën & Bijlage IV & Bijlage II & - & - \\
\hline Poelkikker & Rana lessonae & Amfibieën & Bijlage IV & & - & - \\
\hline Rugstreeppad & Bufo calamita & Amfibieën & Bijlage IV & Bijlage II & - & - \\
\hline Vroedmeesterpad & Alytes obstetricans ssp. obstetricans & Amfibieën & Bijlage IV & Bijlage II & - & - \\
\hline Apollovlinder & Parnassius apollo & Dagvlinders & Bijlage IV & Bijlage II & E- & - \\
\hline Boszandoog & Lopinga achine & Dagvlinders & Bijlage IV & Bijlage II & E- & - \\
\hline Donker pimpernelblauwtje & Phengaris nausithous & Dagvlinders & Bijlage IV & Bijlage II & - & - \\
\hline Moerasparelmoervlinder & Euphydryas aurinia ssp. aurinia & Dagvlinders & - & Bijlage II & - & - \\
\hline Pimpernelblauwtje & Phengaris teleius & Dagvlinders & Bijlage IV & Bijlage II & - & - \\
\hline Tijmblauwtje & Phengaris arion & Dagvlinders & Bijlage IV & Bijlage II & - & - \\
\hline Zilverstreephooibeestje & Coenonympha hero & Dagvlinders & Bijlage IV & Bijlage II & - & - \\
\hline Oeveraas & Palingenia longicauda & Haften & - & Bijlage II & - & - \\
\hline Brede & Dytiscus latissimus & Kevers & Bijlage IV & Bijlage II & - & - \\
\hline Gestreepte waterroofkever & Graphoderus bilineatus & Kevers & Bijlage IV & Bijlage II & - & - \\
\hline Juchtleerkever & Osmoderma eremita & Kevers & Bijlage IV & Bijlage II & - & - \\
\hline Vermiljoenkever & Cucujus cinnaberinus & Kevers & Bijlage IV & Bijlage II & - & - \\
\hline Lederschildpad & Dermochelys coriacea & Lederschildpadden & Bijlage IV & Bijlage II & Bijlage I & - \\
\hline Bronslibel & Oxygastra curtisii & Libellen & Bijlage IV & Bijlage II & - & - \\
\hline Groene glazenmaker & Aeshna viridis & Libellen & Bijlage IV & Bijlage II & - & - \\
\hline Mercuurwaterjuffer & Coenagrion mercuriale ssp. mercuriale & Libellen & - & Bijlage II & E- & E- \\
\hline Noordse winterjuffer & Sympecma annulata ssp. braueri & Libellen & Bijlage IV & Bijlage II & - & - \\
\hline Oostelijke witsnuitlibel & Leucorrhinia albifrons & Libellen & Bijlage IV & Bijlage II & - & - \\
\hline Rivierrombout & Gomphus flavipes ssp. flavipes & Libellen & Bijlage IV & Bijlage II & - & - \\
\hline Sierlijke witsnuitlibel & Leucorrhinia caudalis & Libellen & Bijlage IV & Bijlage II & - & - \\
\hline Teunisbloempijlstaart & Proserpinus proserpina & Nachtvlinders & Bijlage IV & Bijlage II & - & - \\
\hline Gladde slang & Coronella austriaca ssp. austriaca & Reptielen & Bijlage IV & Bijlage II & - & - \\
\hline Muurhagedis & Podarcis muralis ssp. brongniardii & Reptielen & Bijlage IV & Bijlage II & - & - \\
\hline Zandhagedis & Lacerta agilis ssp. agilis & Reptielen & Bijlage IV & Bijlage II & - & - \\
\hline Drijvende waterweegbree & Luronium natans & Vaatplanten & Bijlage IV & - & - & - \\
\hline Groenknolorchis & Liparis loeselii & Vaatplanten & Bijlage IV & - & - & - \\
\hline Kruipend moerasscherm & Apium repens & Vaatplanten & Bijlage IV & - & - & 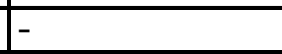 \\
\hline Zomerschroeforchis & Spiranthes aestivalis & Vaatplanten & Bijlage IV & E- & - & - \\
\hline Houting & Coregonus oxyrinchus & Vissen & Bijlage IV & - & - & 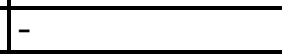 \\
\hline Steur & Acipenser sturio & Vissen & Bijlage IV & Bijlage II & - & - \\
\hline Aasgier & Neophron percnopterus & Vogels & - & Bijlage II & - & Bijlage I \\
\hline Alpengierzwaluw & Tachymarptis melba ssp. melba & Vogels & - & Bijlage II & - & - \\
\hline \begin{tabular}{|l|} 
Alpenheggenmus \\
\end{tabular} & Prunella collaris ssp. collaris & Vogels & - & Bijlage II & - & - \\
\hline Amerikaanse grote stern & Sterna sandvicensis ssp. acuflavida & Vogels & - & Bijlage II & - & - \\
\hline Anatolische woestijnplevier & Charadrius leschenaultii ssp. columbinus & Vogels & - & Bijlage II & - & - \\
\hline Appelvink & Coccothraustes coccothraustes ssp. coccothraustes & Vogels & - & Bijlage II & - & - \\
\hline Aziatische roodborsttapuit & Saxicola torquata ssp. maura & Vogels & - & Bijlage II & - & - \\
\hline Baardgrasmus & Sylvia cantillans ssp. cantillans & Vogels & - & Bijlage II & - & - \\
\hline Baardman & Panurus biarmicus ssp. biarmicus & Vogels & - & Bijlage II & - & - \\
\hline Balearische roodkopklauwier & Lanius senator ssp. badius & Vogels & - & Bijlage II & - & - \\
\hline Balkanbergfluiter & Phylloscopus bonelli ssp. orientalis & Vogels & - & Bijlage II & - & - \\
\hline Balkankwikstaart & Motacilla flava ssp. feldegg & Vogels & E- & Bijlage II & E- & I- \\
\hline
\end{tabular}




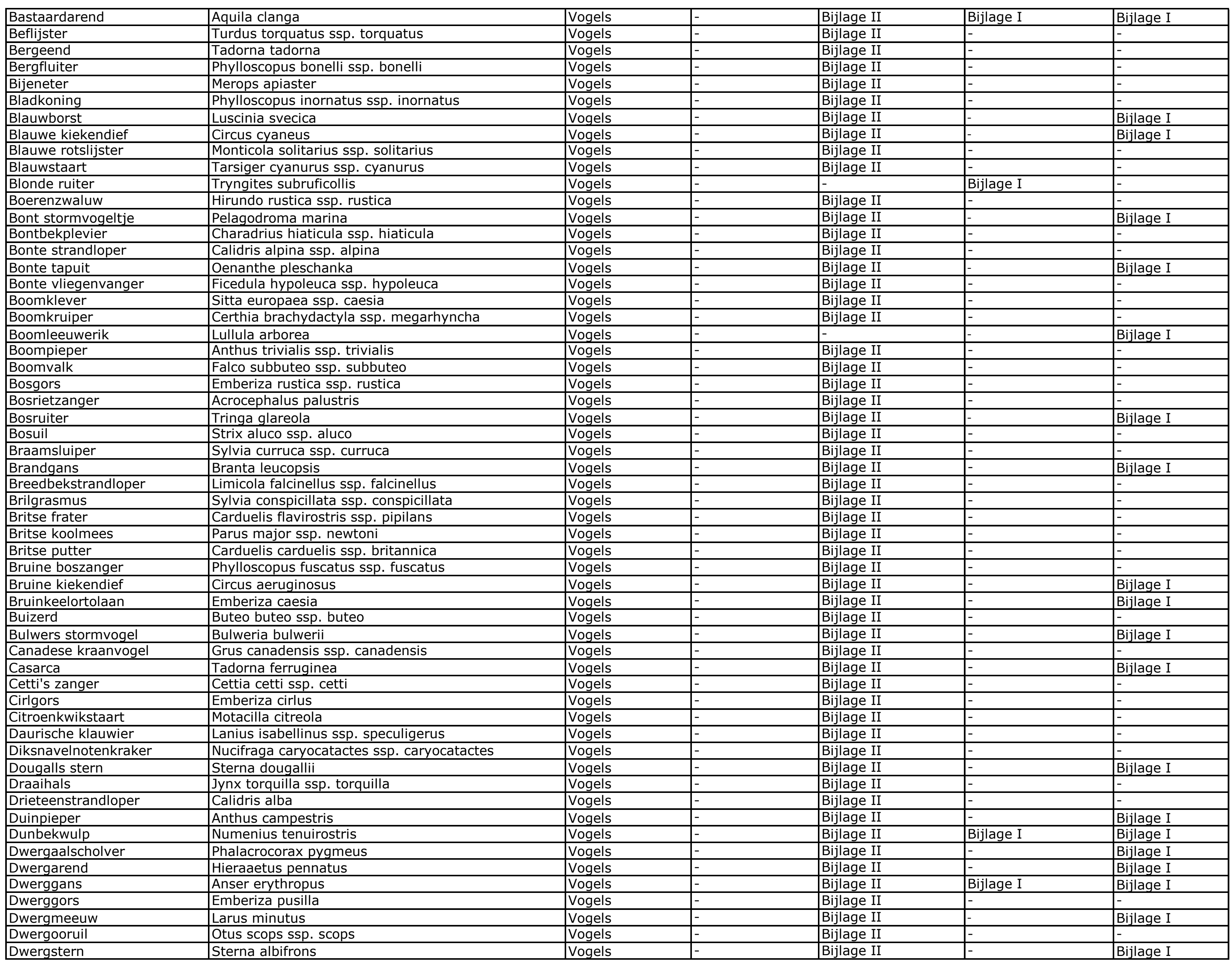




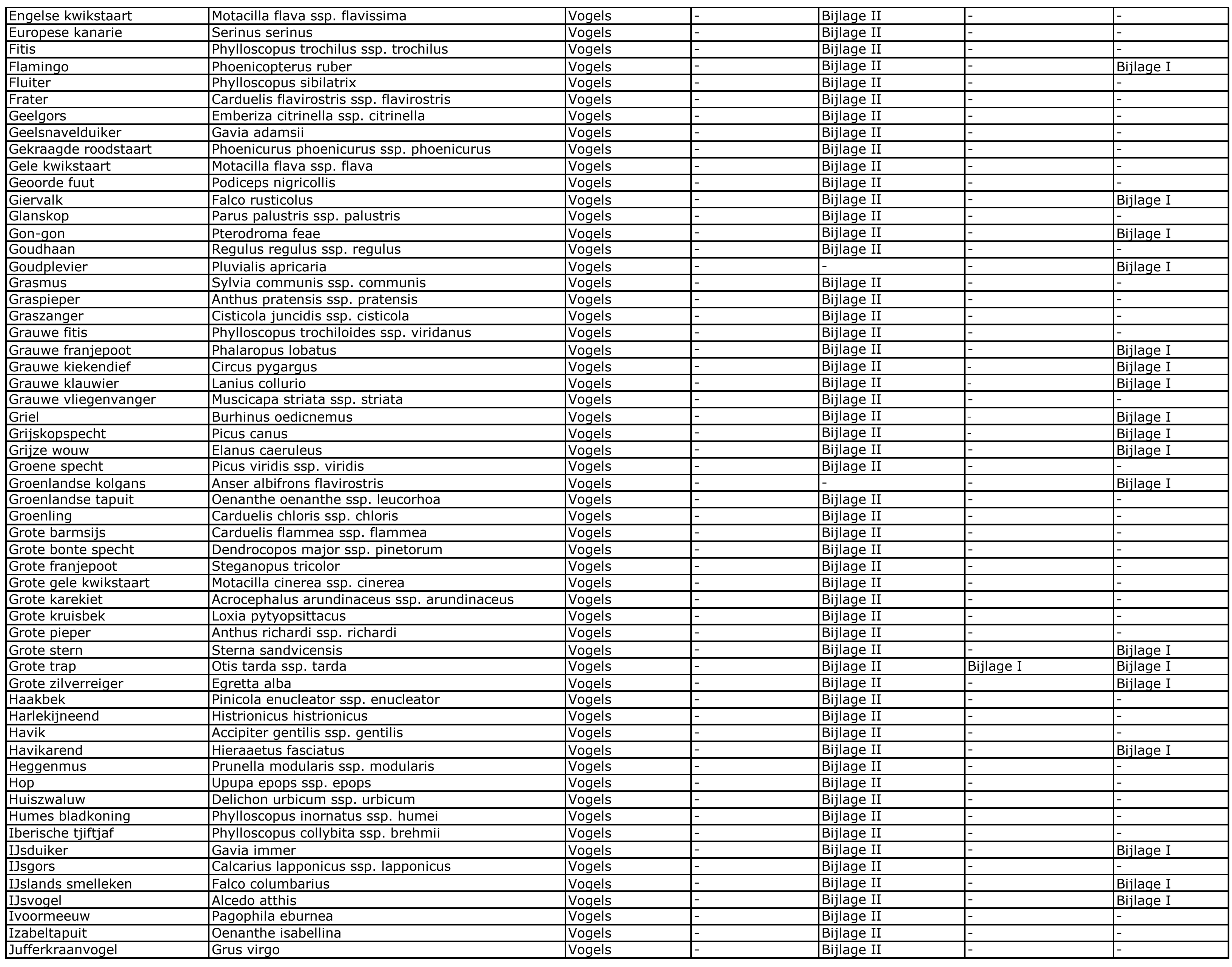




\begin{tabular}{|c|c|c|c|c|c|c|}
\hline Kalanderleeuwerik & Melanocorypha calandra & Vogels & - & Bijlage II & - & Bijlage I \\
\hline Kemphaan & Philomachus pugnax & Vogels & - & & - & Bijlage I \\
\hline Kerkuil & Tyto alba ssp. guttata & Vogels & - & Bijlage II & - & \\
\hline Klapekster & Lanius excubitor ssp. excubitor & Vogels & - & Bijlage II & - & - \\
\hline Klein waterhoen & Porzana parva & Vogels & E & Bijlage II & E & Bijlage I \\
\hline Kleine barmsijs & Carduelis flammea ssp. cabaret & Vogels & E- & Bijlage II & - & - \\
\hline Kleine bonte specht & Dendrocopos minor ssp. hortorum & Vogels & E- & Bijlage II & - & - \\
\hline Kleine karekiet & Acrocephalus scirpaceus ssp. scirpaceus & Vogels & - & Bijlage II & - & - \\
\hline Kleine klapekster & Lanius minor & Vogels & - & Bijlage II & - & Bijlage I \\
\hline Kleine plevier & Charadrius dubius ssp. curonicus & Vogels & - & Bijlage II & E- & - \\
\hline Kleine spotvogel & Hippolais caligata ssp. caligata & Vogels & - & Bijlage II & E- & - \\
\hline Kleine sprinkhaanzanger & Locustella lanceolata & Vogels & E- & Bijlage II & E- & - \\
\hline Kleine torenvalk & Falco naumanni & Vogels & - & Bijlage II & Bijlage I & Bijlage I \\
\hline Kleine trap & Tetrax tetrax & Vogels & - & Bijlage II & - & Bijlage I \\
\hline Kleine vliegenvanger & Ficedula parva & Vogels & E- & Bijlage II & E & Bijlage I \\
\hline Kleine zilverreiger & Egretta garzetta & Vogels & - & Bijlage II & E & Bijlage I \\
\hline Kleine zwaan & Cygnus bewickii & Vogels & - & Bijlage II & - & Bijlage I \\
\hline Kleine zwartkop & Sylvia melanocephala ssp. melanocephala & Vogels & - & Bijlage II & - & - \\
\hline Kleinst waterhoen & Porzana pusilla & Vogels & - & Bijlage II & - & Bijlage I \\
\hline Kluut & Recurvirostra avosetta & Vogels & - & Bijlage II & E & Bijlage I \\
\hline Kneu & Carduelis cannabina ssp. cannabina & Vogels & E- & Bijlage II & $E$ & - \\
\hline Koereiger & Bubulcus ibis ssp. ibis & Vogels & - & Bijlage II & - & - \\
\hline Koningseider & Somateria spectabilis & Vogels & - & Bijlage II & - & - \\
\hline Kortsnavelboomkruiper & Certhia familiaris ssp. macrodactyla & Vogels & E- & Bijlage II & - & - \\
\hline Kortteenleeuwerik & Calandrella brachydactyla & Vogels & E- & Bijlage II & E- & Bijlage I \\
\hline Kraanvogel & Grus grus & Vogels & - & Bijlage II & E & Bijlage I \\
\hline Krekelzanger & Locustella fluviatilis & Vogels & - & Bijlage II & - & - \\
\hline Kroeskoppelikaan & Pelecanus crispus & Vogels & - & Bijlage II & Bijlage I & Bijlage I \\
\hline Krombekstrandloper & Calidris ferruginea & Vogels & - & Bijlage II & - & - \\
\hline \begin{tabular}{|l|} 
Kruisbek \\
\end{tabular} & Loxia curvirostra ssp. curvirostra & Vogels & - & Bijlage II & - & - \\
\hline Kuhls pijlstormvogel & Calonectris diomedea & Vogels & E- & & - & Bijlage I \\
\hline Kuifduiker & Podiceps auritus & Vogels & - & Bijlage II & - & Bijlage I \\
\hline Kuifkoekoek & Clamator glandarius ssp. glandarius & Vogels & - & Bijlage II & - & - \\
\hline Kuifmees & Parus cristatus ssp. mitratus & Vogels & - & Bijlage II & - & - \\
\hline Kwak & Nycticorax nycticorax & Vogels & - & Bijlage II & - & Bijlage I \\
\hline Kwartelkoning & Crex crex & Vogels & - & Bijlage II & E & Bijlage I \\
\hline \begin{tabular}{|l} 
Lachstern \\
\end{tabular} & Gelochelidon nilotica & Vogels & - & Bijlage II & E- & Bijlage I \\
\hline Lammergier & Gypaetus barbatus & Vogels & - & Bijlage II & E & Bijlage I \\
\hline Lepelaar & Platalea leucorodia & Vogels & - & Bijlage II & - & Bijlage I \\
\hline Matkop & Parus montanus ssp. rhenanus & Vogels & - & Bijlage II & - & \\
\hline Middelste bonte specht & Dendrocopos medius & Vogels & - & Bijlage II & - & Bijlage I \\
\hline Mongoolse pieper & Anthus godlewskii & Vogels & - & Bijlage II & E & - \\
\hline Monniksgier & Aegypius monachus & Vogels & E & Bijlage II & E & Bijlage I \\
\hline Morinelplevier & Charadrius morinellus & Vogels & E- & Bijlage II & - & Bijlage I \\
\hline \begin{tabular}{|l|} 
Nachtegaal \\
\end{tabular} & Luscinia megarhynchos ssp. megarhynchos & Vogels & - & Bijlage II & - & - \\
\hline Noordse fitis & Phylloscopus trochilus ssp. acredula & Vogels & - & Bijlage II & - & - \\
\hline Noordse grote bonte specht & Dendrocopos major ssp. major & Vogels & - & Bijlage II & - & - \\
\hline \begin{tabular}{|l|} 
Noordse kwikstaart \\
\end{tabular} & Motacilla flava ssp. thunbergi & Vogels & - & Bijlage II & - & - \\
\hline Noordse nachtegaal & Luscinia luscinia & Vogels & - & Bijlage II & - & - \\
\hline Noordse pijlstormvogel & Puffinus puffinus & Vogels & - & Bijlage II & - & - \\
\hline \begin{tabular}{|l|} 
Noordse stern \\
\end{tabular} & Sterna paradisaea & Vogels & I- & Bijlage II & E- & Bijlage I \\
\hline
\end{tabular}




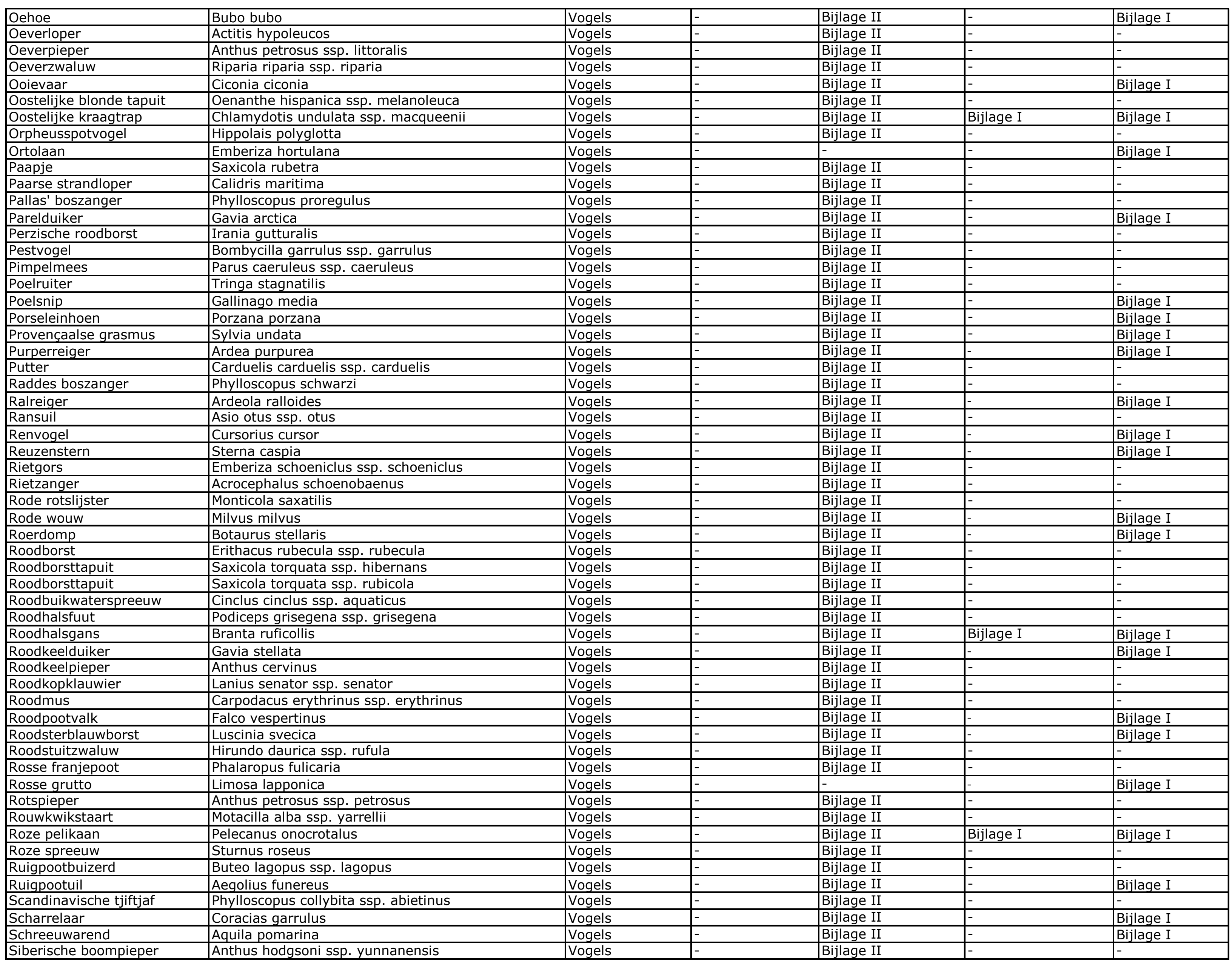




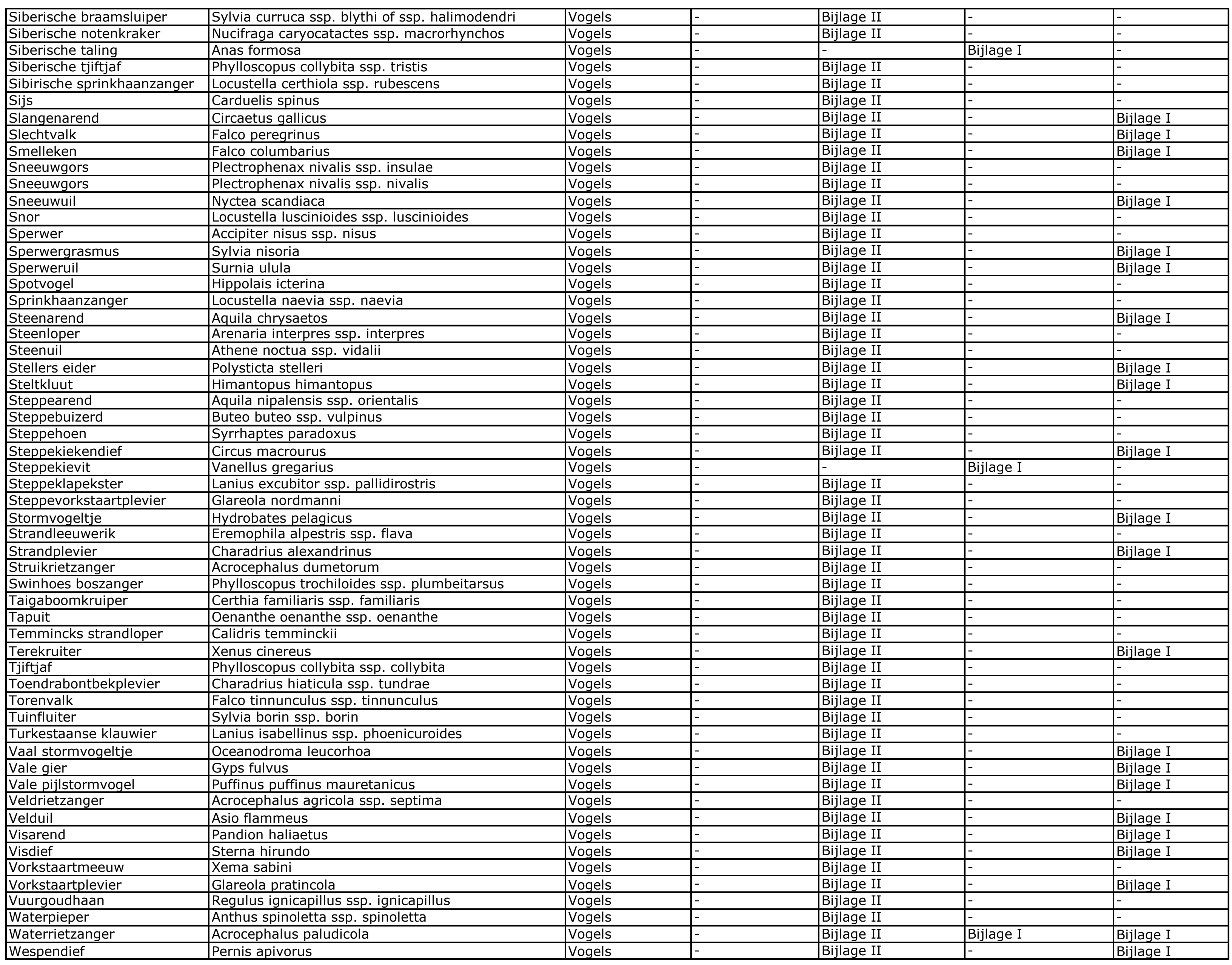




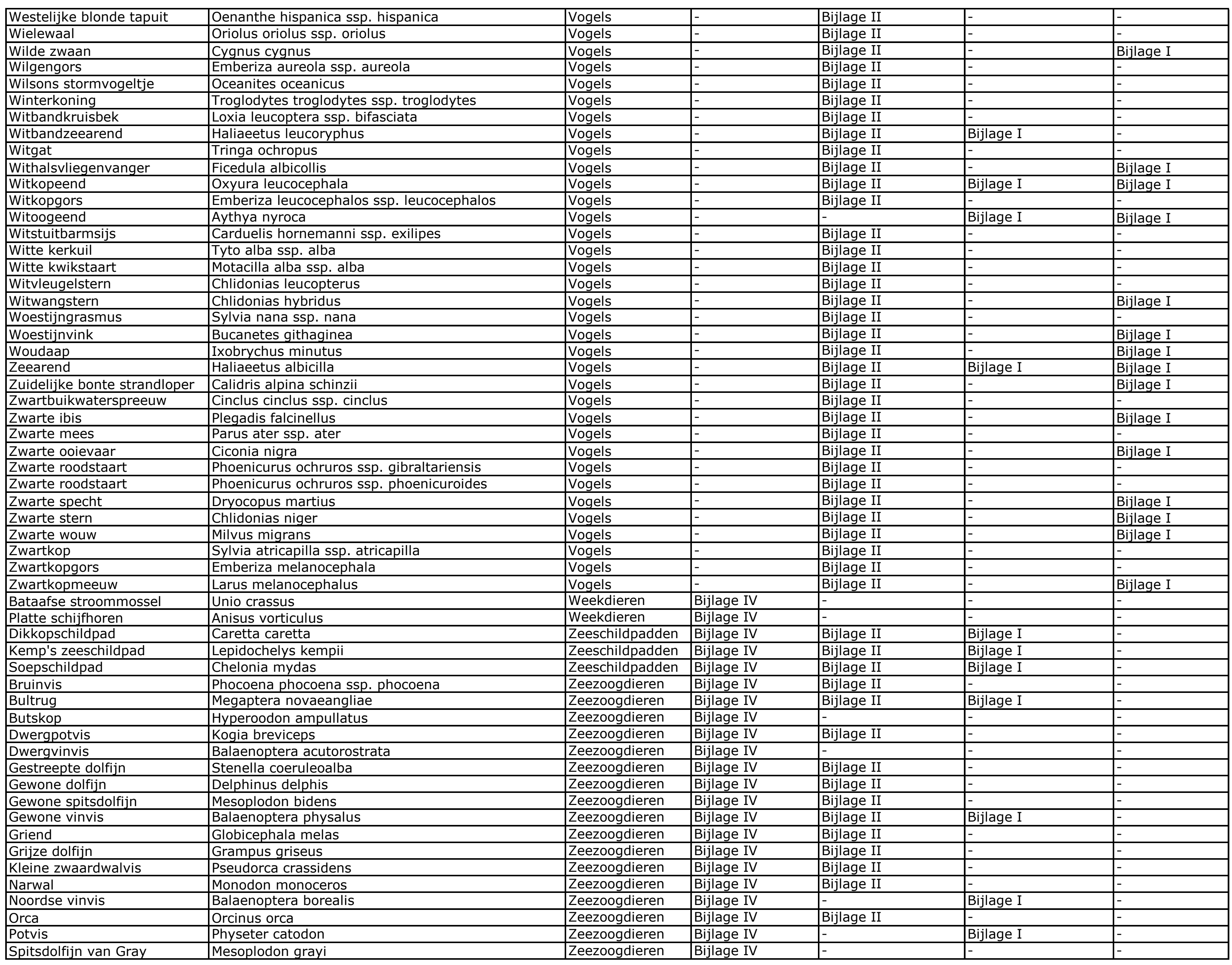




\begin{tabular}{|c|c|c|c|c|c|c|}
\hline Tuimelaar & Tursiops truncatus ssp. truncatus & Zeezoogdieren & Bijlage IV & Bijlage II & T- & - \\
\hline Walrus & Odobenus rosmarus ssp. rosmarus & Zeezoogdieren & - & Bijlage II & - & - \\
\hline Witflankdolfijn & Lagenorhynchus acutus & Zeezoogdieren & Bijlage IV & Bijlage II & - & - \\
\hline \begin{tabular}{|l} 
Witsnuitdolfijn \\
\end{tabular} & Lagenorhynchus albirostris & Zeezoogdieren & Bijlage IV & Bijlage II & - & - \\
\hline Witte dolfijn & Delphinapterus leucas & Zeezoogdieren & Bijlage IV & & - & - \\
\hline Baardvleermuis & Myotis mystacinus ssp. mystacinus & Landzoogdieren & Bijlage IV & Bijlage II & - & - \\
\hline Bechsteins vleermuis & Myotis bechsteini & Landzoogdieren & Bijlage IV & Bijlage II & - & - \\
\hline Bever & Castor fiber ssp. albicus & Landzoogdieren & Bijlage IV & & - & - \\
\hline Bosvleermuis & Nyctalus leisleri ssp. leisleri & Landzoogdieren & Bijlage IV & Bijlage II & - & - \\
\hline Brandts vleermuis & Myotis brandti ssp. brandti & Landzoogdieren & Bijlage IV & Bijlage II & - & - \\
\hline \begin{tabular}{|l} 
Franjestaart \\
\end{tabular} & Myotis nattereri & Landzoogdieren & Bijlage IV & Bijlage II & - & - \\
\hline Gewone dwergvleermuis & Pipistrellus pipistrellus & Landzoogdieren & Bijlage IV & & - & - \\
\hline Grijze grootoorvleermuis & Plecotus austriacus ssp. austriacus & Landzoogdieren & Bijlage IV & Bijlage II & - & - \\
\hline Grote hoefijzerneus & Rhinolophus ferrumequinum ssp. ferrumequinum & Landzoogdieren & Bijlage IV & Bijlage II & - & - \\
\hline Grote rosse vleermuis & Nyctalus lasiopterus & Landzoogdieren & Bijlage IV & Bijlage II & - & - \\
\hline Hamster & Cricetus cricetus ssp. canescens & Landzoogdieren & Bijlage IV & Bijlage II & E & - \\
\hline Hazelmuis & Muscardinus avellanarius & Landzoogdieren & Bijlage IV & & - & - \\
\hline Ingekorven vleermuis & Myotis emarginatus ssp. emarginatus & Landzoogdieren & Bijlage IV & Bijlage II & - & - \\
\hline Kleine dwergvleermuis & Pipistrellus pygmaeus & Landzoogdieren & Bijlage IV & & - & - \\
\hline Kleine hoefijzerneus & Rhinolophus hipposideros ssp. hipposideros & Landzoogdieren & Bijlage IV & Bijlage II & - & - \\
\hline \begin{tabular}{|l|} 
Laatvlieger \\
\end{tabular} & Eptesicus serotinus ssp. serotinus & Landzoogdieren & Bijlage IV & Bijlage II & E & E- \\
\hline Lynx & Lynx Iynx ssp. Iynx & Landzoogdieren & Bijlage IV & & - & - \\
\hline Meervleermuis & Myotis dasycneme & Landzoogdieren & Bijlage IV & Bijlage II & - & - \\
\hline Noordse vleermuis & Eptesicus nilssoni ssp. nilssoni & Landzoogdieren & Bijlage IV & Bijlage II & - & - \\
\hline Noordse woelmuis & Microtus oeconomus ssp. arenicola & Landzoogdieren & Bijlage IV & & - & - \\
\hline Otter & Lutra lutra ssp. lutra & Landzoogdieren & Bijlage IV & Bijlage II & E & - \\
\hline Rosse vleermuis & Nyctalus noctula ssp. noctula & Landzoogdieren & Bijlage IV & Bijlage II & - & - \\
\hline Ruige dwergvleermuis & Pipistrellus nathusii & Landzoogdieren & Bijlage IV & Bijlage II & - & - \\
\hline Tweekleurige vleermuis & Vespertilio murinus ssp. murinus & Landzoogdieren & Bijlage IV & Bijlage II & - & - \\
\hline Vale vleermuis & Myotis myotis ssp. myotis & Landzoogdieren & Bijlage IV & Bijlage II & - & - \\
\hline Watervleermuis & Myotis daubentoni ssp. daubentoni & Landzoogdieren & Bijlage IV & Bijlage II & I- & E- \\
\hline
\end{tabular}




\section{Bijlage 5 Lijst van waargenomen mariene soorten die op bijlage II, III en IV van de habitatrichtlijn staan}

Overzicht van soorten die genoemd zijn in bijlage II, IV en/of V van de Habitatrichtlijn en die na 1900 in het wild in Nederland zijn waargenomen

(http://minez.nederlandsesoorten.nl/content/habitatrichtlijn). Met uitzondering van een aantal vleermuissoorten* zijn alleen de mariene soorten hier weergegeven, inclusief het voorkomen in de Nederlandse Noordzee (de status volgens het Nederlands soortregister van het ministerie van EZ (nu LNV; http://minez.nederlandsesoorten.nl/soorten), uitgezonderd vleermuissoorten).

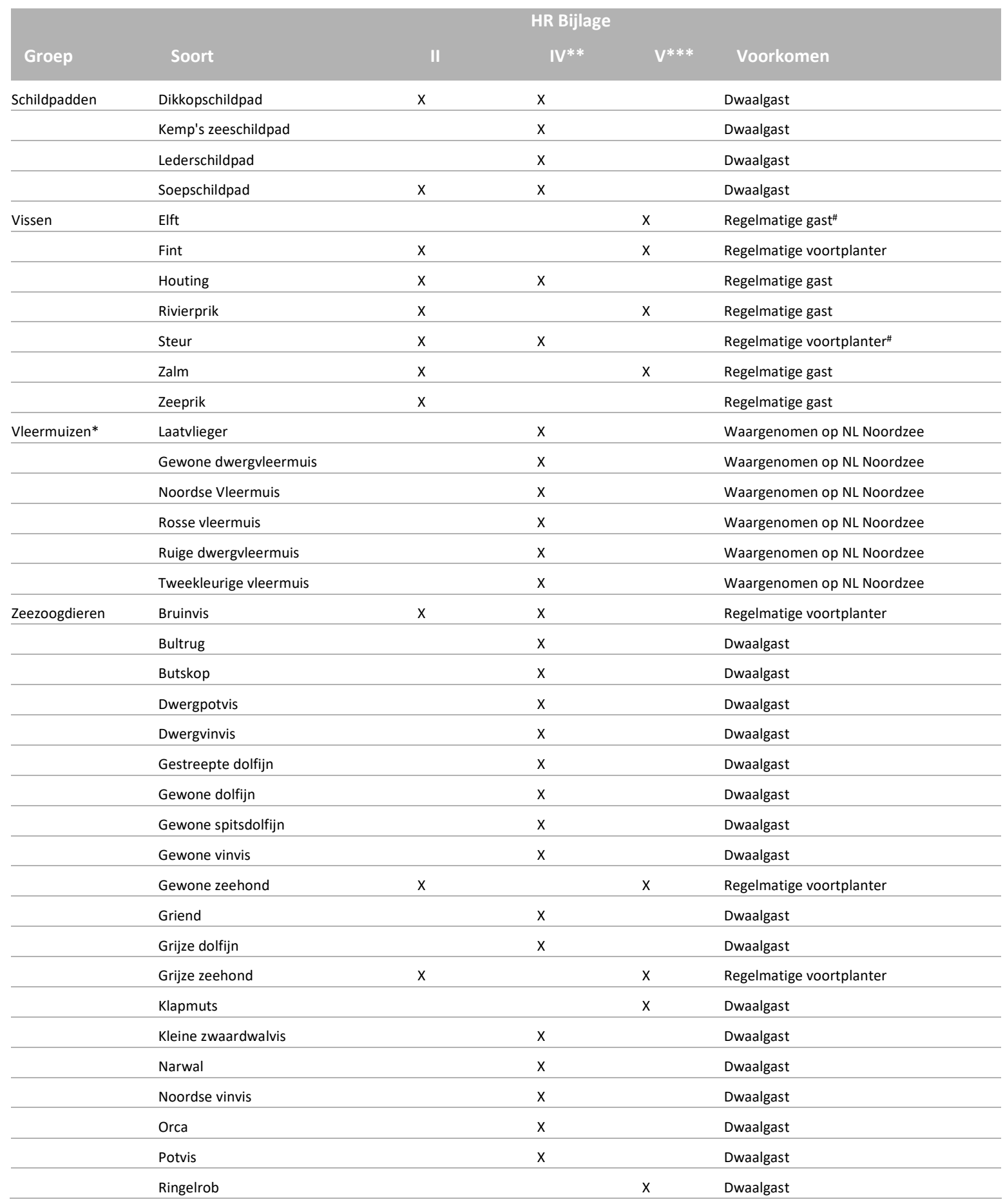




\begin{tabular}{|c|c|c|c|c|c|}
\hline \multirow[b]{2}{*}{ Groep } & \multicolumn{5}{|c|}{ HR Biflage } \\
\hline & Soort & II & IV** & $\mathbf{V}^{* * *}$ & Voorkomen \\
\hline & Spitsdolfijn van Gray & & $x$ & & Dwaalgast \\
\hline & Tuimelaar & $x$ & $x$ & & Regelmatige voortplanter ${ }^{\#}$ \\
\hline & Walrus & & $x$ & & Dwaalgast \\
\hline & Witflankdolfijn & & $x$ & & Dwaalgast \\
\hline & Witsnuitdolfijn & & $x$ & & Regelmatige voortplanter \\
\hline & Witte dolfijn & & $x$ & & Dwaalgast \\
\hline & Zadelrob & & & $x$ & Dwaalgast \\
\hline
\end{tabular}

*Voor wat betreft vleermuizen zijn alleen de soorten weergegeven die zijn waargenomen op de Nederlandse Noordzee, op basis van Leopold et al. (2014); ** incl. Bern annex II en Bonn annex I; *** incl. Bern annex III en Bonn annex II ; \#Status ter discussie

Deze bijlage is overgenomen uit Tamis, J.E., R.H. Jongbloed, A. Asjes, P. de Vries, G.J. Piet (2019): NatuurBalans Noordzee. Voorbeeld uitwerking van een Noordzee bijdrage aan de Balans van de Leefomgeving. Wageningen University \& Research rapport C034/19. 
Bijlage 6 AERIUS ${ }^{\circledR}$-Calculator resultaten

voor de verwachte

stikstofuitstoot van de

voorgenomen activiteiten 


\section{AERIUS À CALCULATOR}

Dit document bevat rekenresultaten van AERIUS Calculator. Het betreft de hoogst berekende stikstofbijdragen per

stikstofgevoelig Natura 2000-gebied, op basis van rekenpunten die overlappen met habitattypen en/of leefgebieden die aangewezen zijn in het kader van de Wet natuurbescherming, gekoppeld aan een aangewezen soort, of nog onbekend maar mogelijk wel relevant.

De berekening op basis van stikstofemissies gaat uit van de componenten ammoniak (NHz) en/of stikstofoxide (NOx).

Wilt u verder rekenen of gegevens wijzigen? Importeer de pdf dan in Calculator. Voor meer toelichting verwijzen wij u naar de website www.aerius.nl.
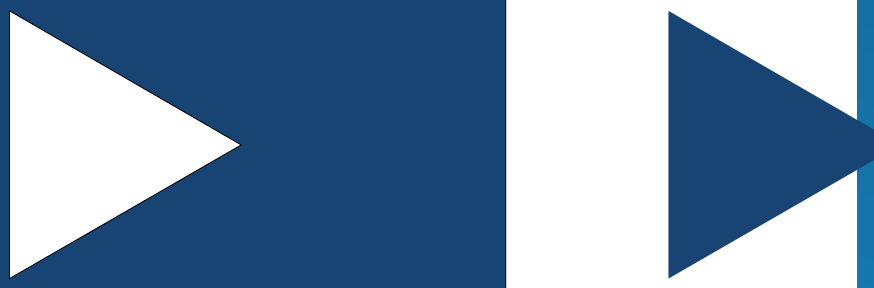

Berekening Situatie 1

- Kenmerken

- Samenvatting emissies

- Depositieresultaten

- Gedetailleerde emissiegegevens

Verdere toelichting over deze PDF kunt u vinden in een bijbehorende leeswijzer. Deze leeswijzer en overige documentatie is te raadplegen via:

https://www.aerius.nl/handleidingen-en-leeswijzers. 
Resultaten

\section{AERIUS Â CALCULATOR}

Contact

Rechtspersoon

Slow Mill Sustainable Power BV

Activiteit

Omschrijving

Pilot Slow Mill

Datum berekening

18 augustus 2020, 13:34

Situatie 1

NOx

$1.088,55 \mathrm{~kg} / \mathrm{j}$

$\mathrm{NH}_{3}$
Inrichtingslocatie

4 km ten westen van Texel (Paal 19), 1796AA Texel

AERIUS kenmerk

Rn1Gr51GuUQK

Rekenjaar

Rekenconfiguratie

2021

Berekend voor natuurgebieden

Totale emissie

Resultaten

Hectare met hoogste bijdrage (mol/ha/j)

Toelichting
Natuurgebied

Bijdrage

Duinen en Lage Land Texel

0,07 


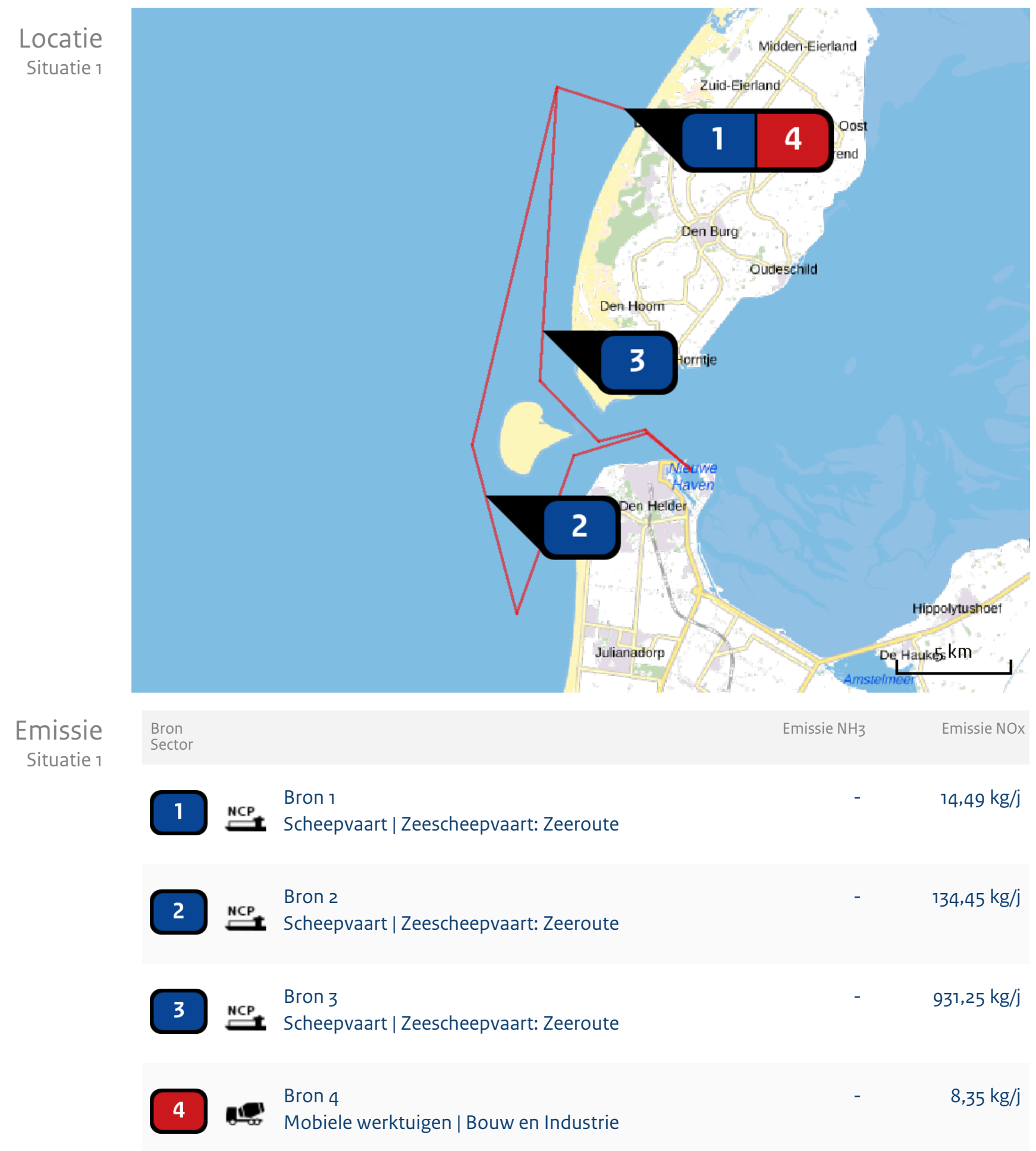




\author{
Resultaten \\ stikstof \\ gevoelige \\ Natura 2000 \\ gebieden \\ (mol/ha/j)
}

Natuurgebied

Hoogste bijdrage

Bijdrage op

\author{
(1)
}

Hoogstebidrage

overbelaste

hexagonen*

Duinen en Lage Land Texel

0,07

Waddenzee

0,01

Duinen Den Helder-Callantsoog

0,01

\begin{abstract}
Als de hoogste depositietoename plaatsvindt op een hexagoon waar géén sprake is van een (naderende) stikstofoverbelasting, dan is de hoogste toename op een hexagoon met wel een (naderende) stikstofoverbelasting in deze kolom weergegeven.
\end{abstract}




\section{Resultaten Duinen en Lage Land Texel}

habitattype

$(\mathrm{mol} / \mathrm{ha} / \mathrm{j})$

voor de 10 stikstofgevoelige Natura 2000gebieden met het hoogste resultaat

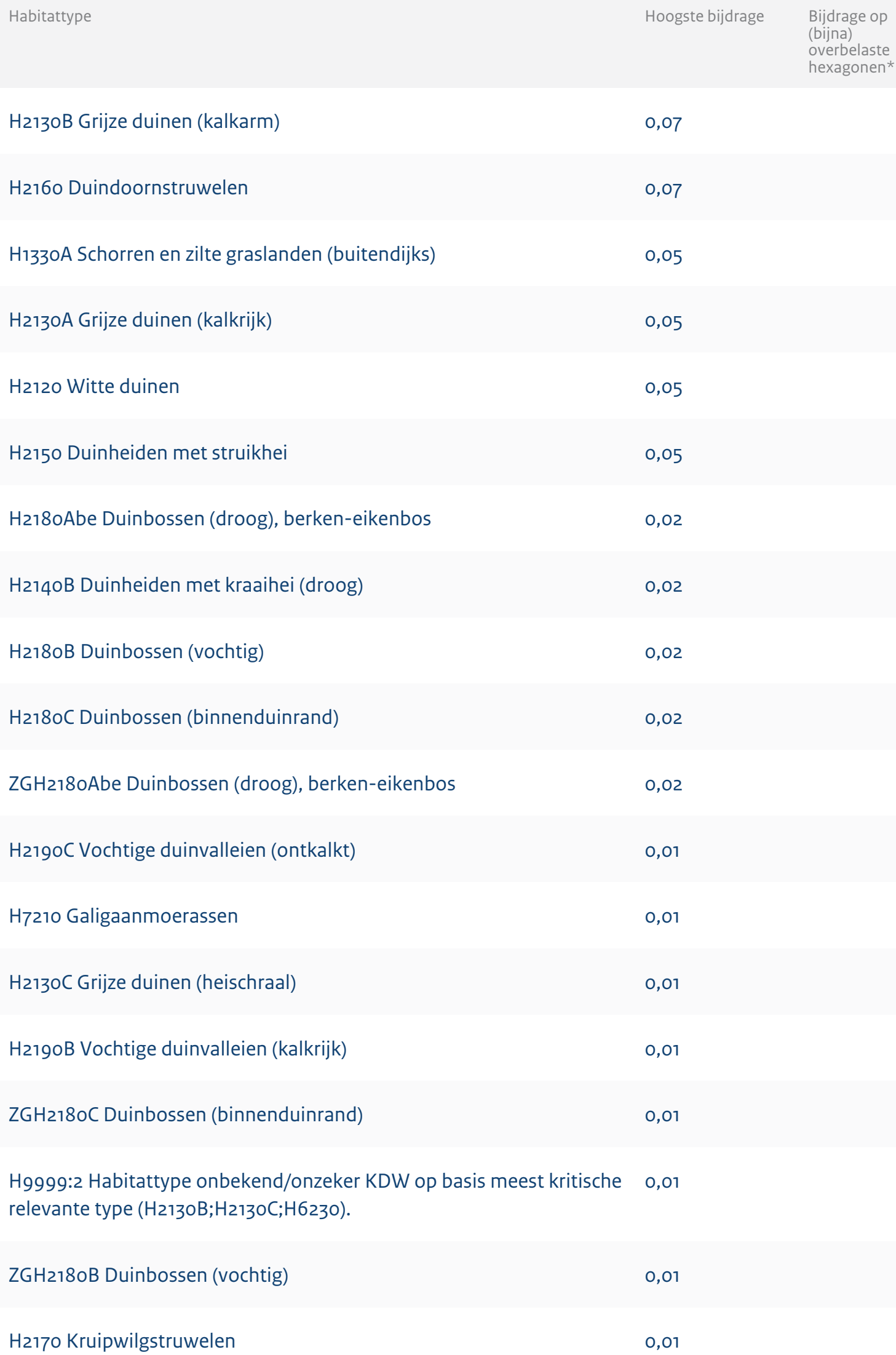

ZGH2180Abe Duinbossen (droog), berken-eikenbos 
Duinen en Lage Land Texel

\begin{tabular}{|c|c|c|}
\hline Habitattype & Hoogste bijdrage & $\begin{array}{l}\text { Bijdrage op } \\
\text { (bijna) } \\
\text { overbelaste } \\
\text { hexagonen* }\end{array}$ \\
\hline $\begin{array}{l}\text { H2190Aom Vochtige duinvalleien (open water), oligo- tot mesotrofe } \\
\text { vormen }\end{array}$ & 0,01 & \\
\hline H2110 Embryonale duinen & 0,01 & \\
\hline H6430C Ruigten en zomen (droge bosranden) & 0,01 & \\
\hline H2140A Duinheiden met kraaihei (vochtig) & 0,01 & \\
\hline H1310B Zilte pionierbegroeiingen (zeevetmuur) & 0,01 & \\
\hline H6230 Heischrale graslanden & 0,01 & \\
\hline H1310A Zilte pionierbegroeiingen (zeekraal) & 0,01 & \\
\hline H1320 Slijkgrasvelden & 0,01 & \\
\hline H1330B Schorren en zilte graslanden (binnendijks) & 0,01 & \\
\hline
\end{tabular}




\section{Waddenzee}

Habitattype

H2120 Witte duinen

0,01

H1330A Schorren en zilte graslanden (buitendijks)

0,01

H2130B Grijze duinen (kalkarm)

0,01

H216o Duindoornstruwelen

0,01

H2110 Embryonale duinen

0,01

H2130A Grijze duinen (kalkrijk)

0,01

H2190B Vochtige duinvalleien (kalkrijk)

0,01

H1310A Zilte pionierbegroeiingen (zeekraal)

0,01

H1320 Slijkgrasvelden

0,01 
Duinen Den Helder-Callantsoog

\begin{tabular}{|c|c|c|}
\hline Habitattype & Hoogste bijdrage & $\begin{array}{l}\text { Bijdrage op } \\
\text { (bijna) } \\
\text { overbelaste } \\
\text { hexagonen* }\end{array}$ \\
\hline H2150 Duinheiden met struikhei & 0,01 & \\
\hline H218oAbe Duinbossen (droog), berken-eikenbos & 0,01 & \\
\hline H2120 Witte duinen & 0,01 & \\
\hline H2130B Grijze duinen (kalkarm) & 0,01 & \\
\hline H2140B Duinheiden met kraaihei (droog) & 0,01 & \\
\hline H218oB Duinbossen (vochtig) & 0,01 & \\
\hline H2190B Vochtige duinvalleien (kalkrijk) & 0,01 & \\
\hline H2140A Duinheiden met kraaihei (vochtig) & 0,01 & \\
\hline H2180C Duinbossen (binnenduinrand) & 0,01 & - \\
\hline H216o Duindoornstruwelen & 0,01 & \\
\hline H2170 Kruipwilgstruwelen & 0,01 & \\
\hline $\begin{array}{l}\text { H2190Aom Vochtige duinvalleien (open water), oligo- tot mesotrofe } \\
\text { vormen }\end{array}$ & 0,01 & \\
\hline H219oC Vochtige duinvalleien (ontkalkt) & 0,01 & \\
\hline $\begin{array}{l}\text { Als de hoogste depositietoename plaatsvindt op een hexagoon waar } \\
\text { géén sprake is van een (naderende) stikstofoverbelasting, dan is de } \\
\text { hoogste toename op een hexagoon met wel een (naderende) } \\
\text { stikstofoverbelasting in deze kolom weergegeven. }\end{array}$ & & \\
\hline
\end{tabular}




\author{
Emissie \\ (per bron) \\ Situatie 1
}

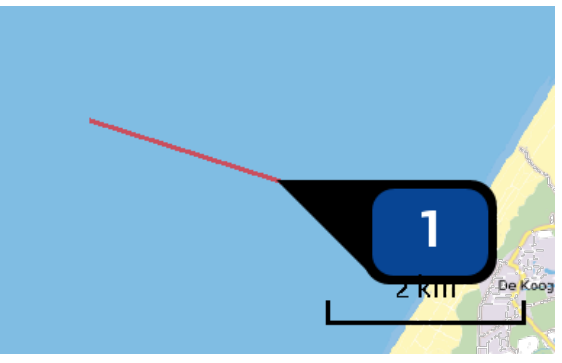

Naam

Locatie $(X, Y)$

NOx

Omschrijving

M/V RAM

Sleepboten,

werkschepen en

overige GT: 100-1599

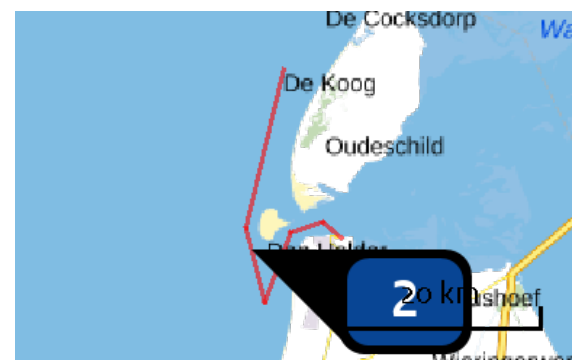

Naam

Locatie $(X, Y)$

NOx

Omschrijving

M/V RAM

Sleepboten,

werkschepen en

overige GT: 100-1599

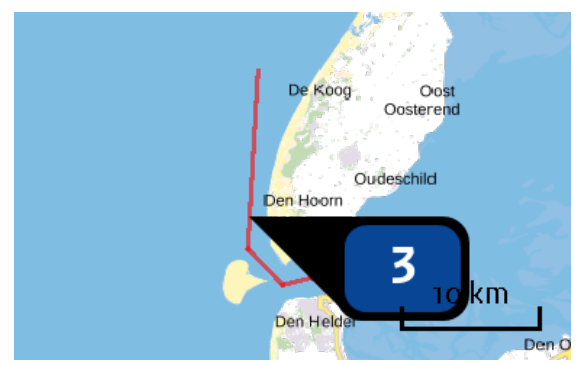

Naam

Locatie $(X, Y)$

NOx

\section{Bron 1}

110797, 569172

$14,49 \mathrm{~kg} / \mathrm{j}$
Aantal bezoeken Stof

$6 /$ jaar NOx
Emissie

$14,49 \mathrm{~kg} / \mathrm{j}$
Bron 2

105765, 551846

$134,45 \mathrm{~kg} / \mathrm{j}$
Aantal bezoeken Stof

6 / jaar NOx
Emissie $134,45 \mathrm{~kg} / \mathrm{j}$
Scheepstype

Sleepboten,

werkschepen en

overige GT: 100-1599
Omschrijving

Empiric
Bron 3 108266, 559105 $931,25 \mathrm{~kg} / \mathrm{j}$
Aantal bezoeken Stof

72 / jaar NOx

$931,25 \mathrm{~kg} / \mathrm{j}$ 


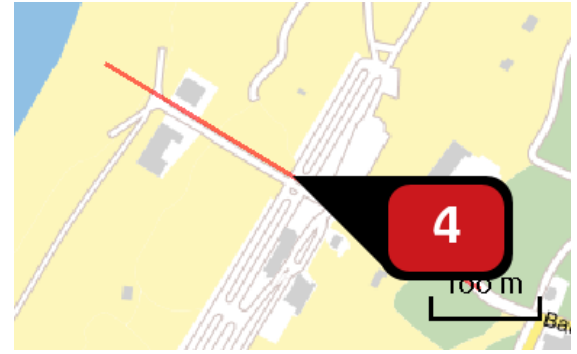

Voertuig

AFW
Omschrijving

Graafmachine
Naam

Locatie $(X, Y)$

NOx

Brandstof verbruik (I/j)
Bron 4

112863,568462

$8,35 \mathrm{~kg} / \mathrm{j}$ $\begin{array}{rrr}\begin{array}{r}\text { Uitstoot } \\ \text { hoogte }\end{array} & \begin{array}{r}\text { Spreiding } \\ (\mathrm{m})\end{array} & \begin{array}{r}\text { Warmte } \\ \text { inhoud } \\ (\mathrm{mW})\end{array}\end{array}$

2,5
4,0

$0,2 \mathrm{NOx}$
Emissie $8,35 \mathrm{~kg} / \mathrm{j}$ 
Hoewel verstrekte gegevens kunnen dienen ter onderbouwing van een vergunningaanvraag, kunnen er geen rechten aan worden ontleend. De eigenaar van AERIUS aanvaardt geen aansprakelijkheid voor de inhoud van de door de gebruiker aangeboden informatie. Bovenstaande gegevens zijn enkel bruikbaar tot er een nieuwe versie van AERIUS beschikbaar is. AERIUS is een geregistreerd handelsmerk in Europa. Alle rechten die niet expliciet worden verleend, zijn voorbehouden.

Rekenbasis Deze berekening is tot stand gekomen op basis van:

AERIUS versie 2019A_20200805_f3dee6357e

Database versie 2019A_20200805_f3dee6357e

Voor meer informatie over de gebruikte methodiek en data zie:

https://www.aerius.nl/nl/factsheets/release/aerius-calculator-2019A 


\section{AERIUS À CALCULATOR}

Dit document bevat rekenresultaten van AERIUS Calculator. Het betreft de hoogst berekende stikstofbijdragen per

stikstofgevoelig Natura 2000-gebied, op basis van rekenpunten die overlappen met habitattypen en/of leefgebieden die aangewezen zijn in het kader van de Wet natuurbescherming, gekoppeld aan een aangewezen soort, of nog onbekend maar mogelijk wel relevant.

De berekening op basis van stikstofemissies gaat uit van de componenten ammoniak (NHz) en/of stikstofoxide (NOx).

Wilt u verder rekenen of gegevens wijzigen? Importeer de pdf dan in Calculator. Voor meer toelichting verwijzen wij u naar de website www.aerius.nl.
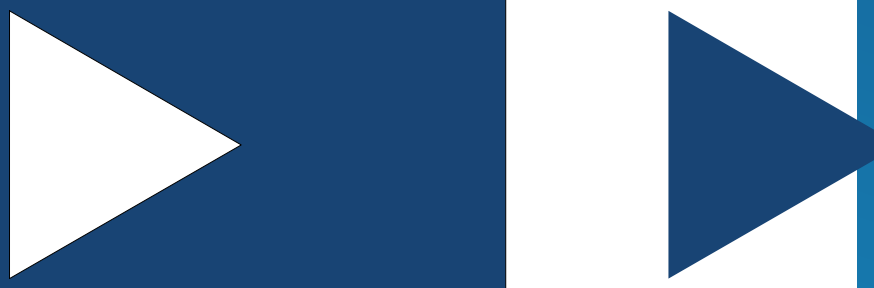

Berekening Situatie 1

- Kenmerken

- Samenvatting emissies

- Depositieresultaten

- Gedetailleerde emissiegegevens

Verdere toelichting over deze PDF kunt u vinden in een bijbehorende leeswijzer. Deze leeswijzer en overige documentatie is te raadplegen via:

https://www.aerius.nl/handleidingen-en-leeswijzers.

RVcMwJXmpumJ (18 augustus 2020) 
Resultaten

\section{AERIUS Â CALCULATOR}

Contact

Rechtspersoon

Slow Mill Sustainable Power BV

Activiteit

Omschrijving

Pilot Slow Mill

Datum berekening

18 augustus 2020, 14:03

Situatie 1

NOx

$370,37 \mathrm{~kg} / \mathrm{j}$

$\mathrm{NH}_{3}$

Inrichtingslocatie

4 km ten westen van Texel (Paal 19), 1796AA Texel

AERIUS kenmerk

RVcMwJXmpumJ

Rekenjaar

2022
Rekenconfiguratie

Berekend voor natuurgebieden

Totale emissie

Resultaten

Hectare met hoogste bijdrage (mol/ha/j)

\section{Toelichting}

Natuurgebied

Bijdrage

Duinen en Lage Land Texel

0,01 


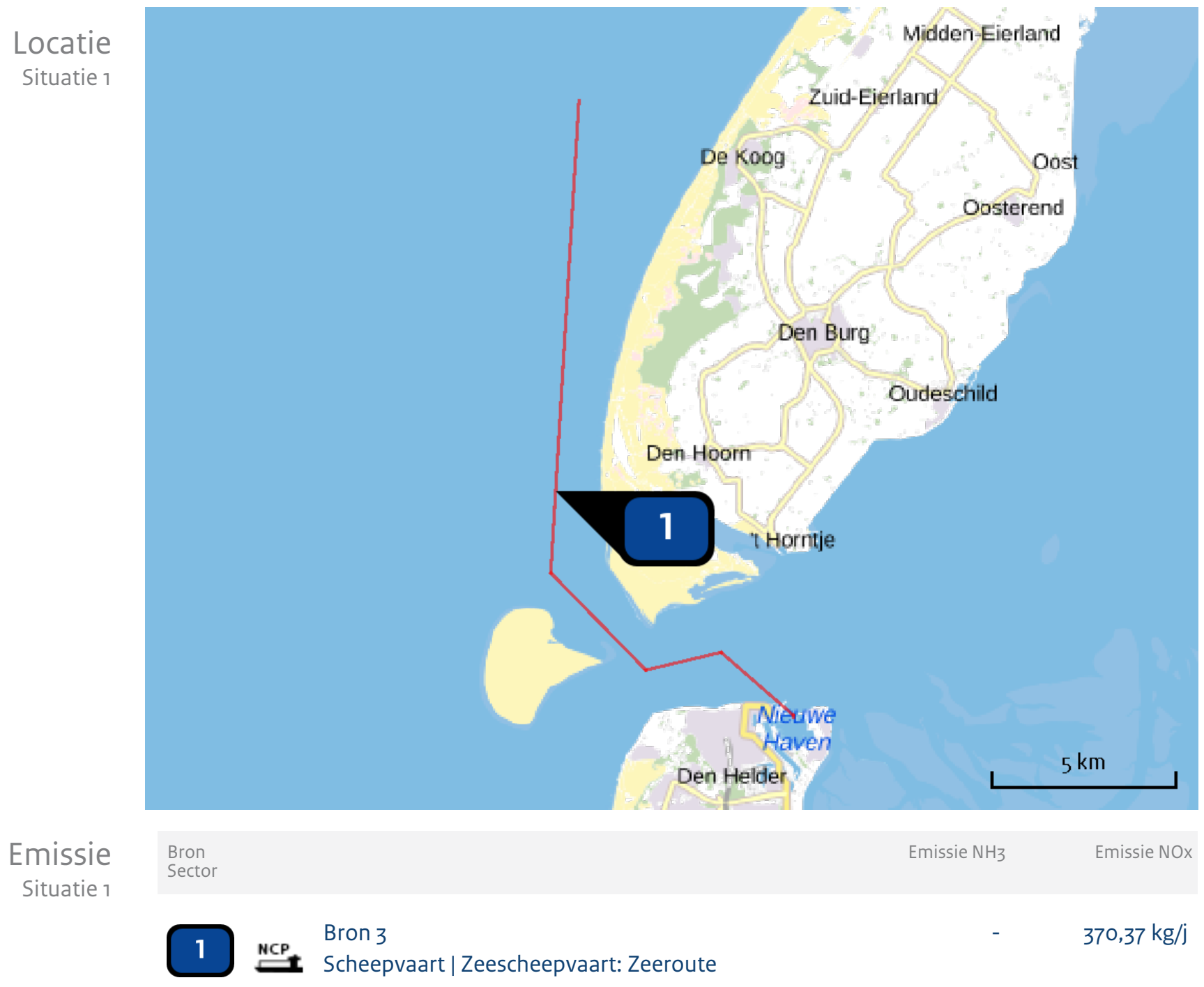


Resultaten

stikstof

gevoelige

Natura 2000

gebieden

(mol/ha/j)
Natuurgebied

Duinen en Lage Land Texel
Hoogste bijdrage

Bijdrage op

(bijna)

overbelaste

hexagonen*

0,01

* Als de hoogste depositietoename plaatsvindt op een hexagoon waar géén sprake is van een (naderende) stikstofoverbelasting, dan is de hoogste toename op een hexagoon met wel een (naderende) stikstofoverbelasting in deze kolom weergegeven. 


\section{Resultaten Duinen en Lage Land Texel}

habitattype

$(\mathrm{mol} / \mathrm{ha} / \mathrm{j})$

voor de 10 stikstofgevoelige

Natura 2000gebieden met het hoogste resultaat

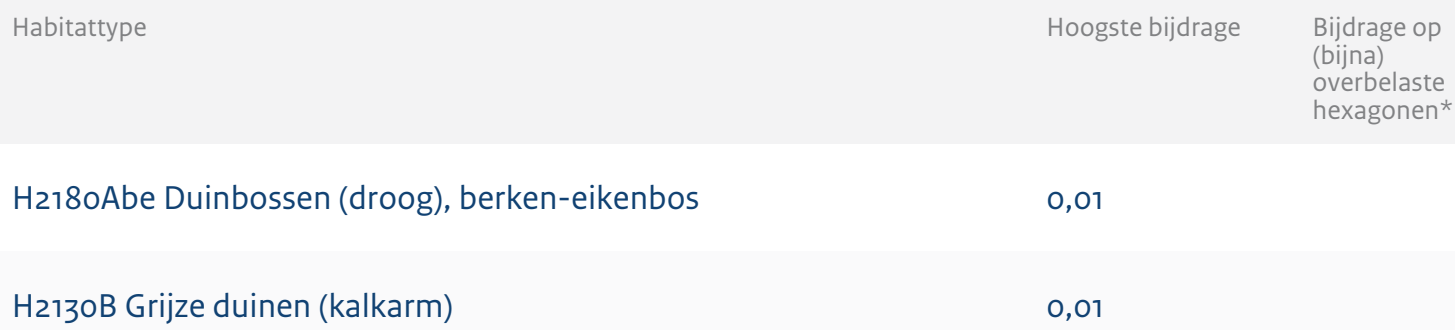

H7210 Galigaanmoerassen

0,01

H2130C Grijze duinen (heischraal)

H219oB Vochtige duinvalleien (kalkrijk)

0,01

H2130A Grijze duinen (kalkrijk)

0,01

H216o Duindoornstruwelen

0,01

H2120 Witte duinen

0,01

H1330A Schorren en zilte graslanden (buitendijks)

ZGH2180C Duinbossen (binnenduinrand)

0,01

ZGH2180B Duinbossen (vochtig) 


\author{
Emissie \\ (per bron) \\ Situatie 1
}

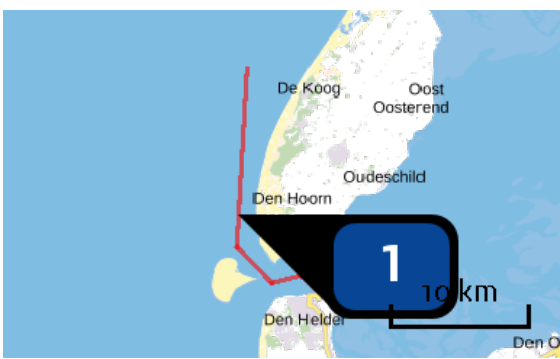

Naam
Locatie $(X, Y)$
NOx
Bron 3

108266, 559105

$370,37 \mathrm{~kg} / \mathrm{j}$

\begin{abstract}
Scheepstype
Omschrijving

Sleepboten,

werkschepen en

overige GT: 100-1599

Empiric

Empicic
\end{abstract}

Aantal bezoeken Stof

30 / jaar NOx
Emissie

$370,37 \mathrm{~kg} / \mathrm{j}$ 
Hoewel verstrekte gegevens kunnen dienen ter onderbouwing van een vergunningaanvraag, kunnen er geen rechten aan worden ontleend. De eigenaar van AERIUS aanvaardt geen aansprakelijkheid voor de inhoud van de door de gebruiker aangeboden informatie. Bovenstaande gegevens zijn enkel bruikbaar tot er een nieuwe versie van AERIUS beschikbaar is. AERIUS is een geregistreerd handelsmerk in Europa. Alle rechten die niet expliciet worden verleend, zijn voorbehouden.

Rekenbasis Deze berekening is tot stand gekomen op basis van:

AERIUS versie 2019A_20200805_f3dee6357e

Database versie 2019A_20200805_f3dee6357e

Voor meer informatie over de gebruikte methodiek en data zie:

https://www.aerius.nl/nl/factsheets/release/aerius-calculator-2019A 


\section{AERIUS À CALCULATOR}

Dit document bevat rekenresultaten van AERIUS Calculator. Het betreft de hoogst berekende stikstofbijdragen per

stikstofgevoelig Natura 2000-gebied, op basis van rekenpunten die overlappen met habitattypen en/of leefgebieden die aangewezen zijn in het kader van de Wet natuurbescherming, gekoppeld aan een aangewezen soort, of nog onbekend maar mogelijk wel relevant.

De berekening op basis van stikstofemissies gaat uit van de componenten ammoniak (NHz) en/of stikstofoxide (NOx).

Wilt u verder rekenen of gegevens wijzigen? Importeer de pdf dan in Calculator. Voor meer toelichting verwijzen wij u naar de website www.aerius.nl.
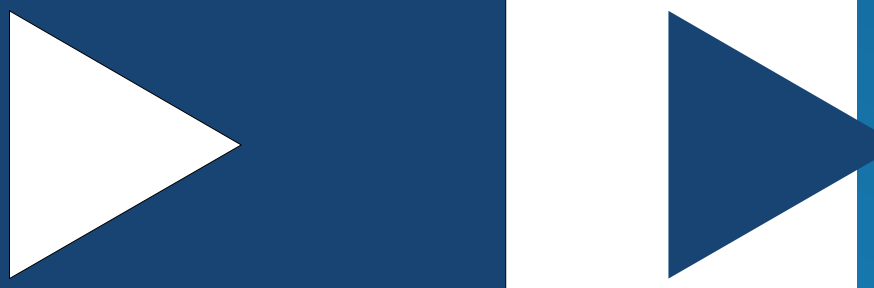

Berekening Situatie 1

- Kenmerken

- Samenvatting emissies

- Depositieresultaten

- Gedetailleerde emissiegegevens

Verdere toelichting over deze PDF kunt u vinden in een bijbehorende leeswijzer. Deze leeswijzer en overige documentatie is te raadplegen via:

https://www.aerius.nl/handleidingen-en-leeswijzers. 
Resultaten

\section{AERIUS Â CALCULATOR}

Contact

Rechtspersoon

Slow Mill Sustainable Power BV

Activiteit

Omschrijving

Pilot Slow Mill

Datum berekening

18 augustus 2020, 14:02

Situatie 1

NOx

$75,12 \mathrm{~kg} / \mathrm{j}$

$\mathrm{NH}_{3}$

Inrichtingslocatie

4 km ten westen van Texel (Paal 19), 1796AA Texel

AERIUS kenmerk

Rt3hCU6R8gr4

Rekenjaar

2026
Rekenconfiguratie

Berekend voor natuurgebieden

Totale emissie

Resultaten

Hectare met hoogste bijdrage (mol/ha/j)

Toelichting
Natuurgebied

Bijdrage

Duinen en Lage Land Texel

0,02 


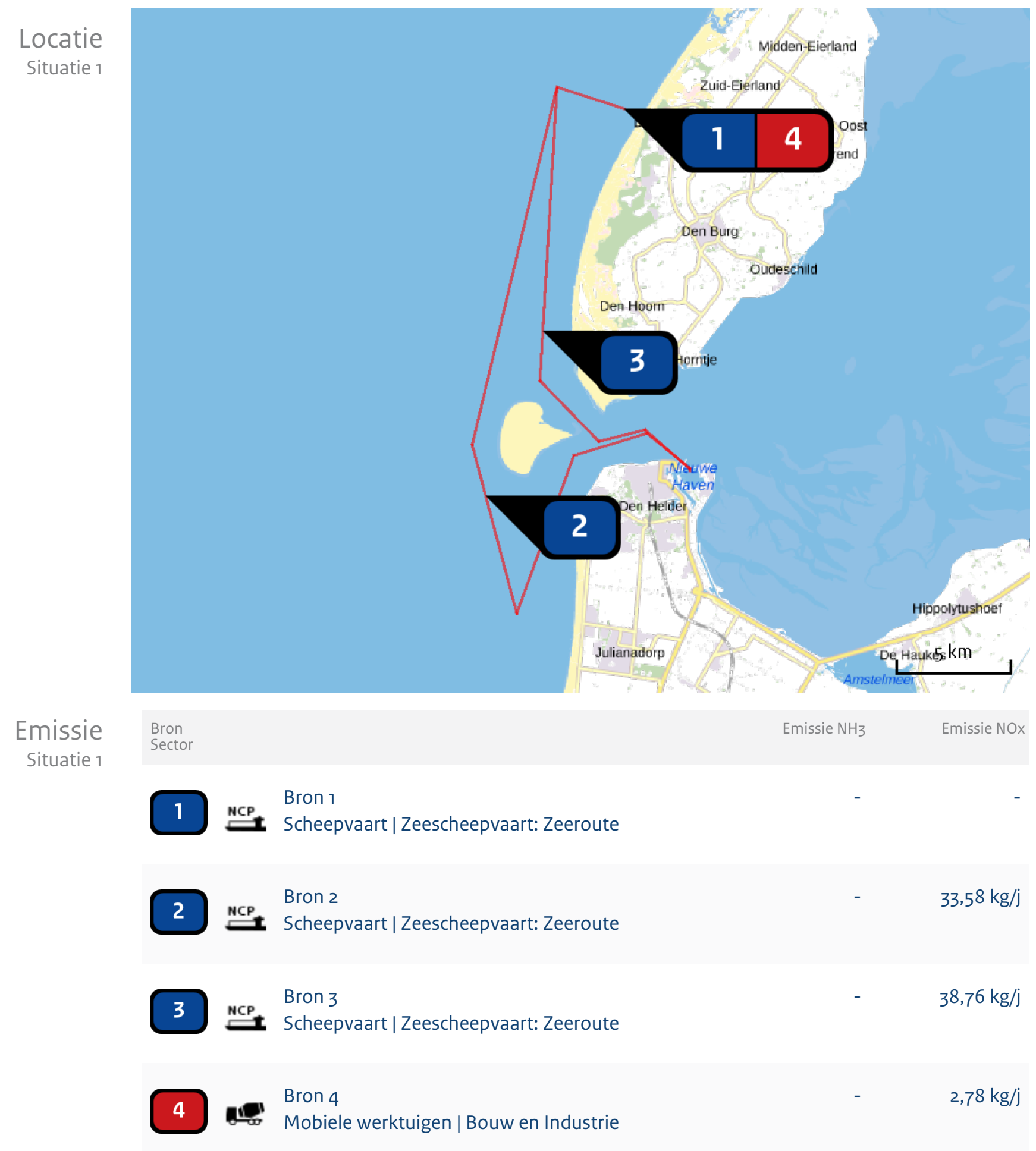


Resultaten

stikstof

gevoelige

Natura 2000

gebieden

(mol/ha/j)
Natuurgebied

Duinen en Lage Land Texel
Hoogste bijdrage

Bijdrage op

(bijna)

overbelaste

hexagonen*

0,02

* Als de hoogste depositietoename plaatsvindt op een hexagoon waar géén sprake is van een (naderende) stikstofoverbelasting, dan is de hoogste toename op een hexagoon met wel een (naderende) stikstofoverbelasting in deze kolom weergegeven. 


\section{Resultaten \\ per \\ habitattype \\ $(\mathrm{mol} / \mathrm{ha} / \mathrm{j})$ \\ voor de 10 stikstofgevoelige \\ Natura 2000- gebieden met het hoogste resultaat}

\section{Duinen en Lage Land Texel}

$\begin{array}{lll}\text { Habitattype } & \text { Hoogste bijdrage } & \begin{array}{l}\text { Bijdrage op } \\ \text { (bijna) } \\ \text { overbelaste } \\ \text { hexagonen* }\end{array} \\ \text { H2130B Grijze duinen (kalkarm) } & 0,02 \\ \text { H2160 Duindoornstruwelen } & 0,02\end{array}$

$\begin{array}{ll}\text { H1330A Schorren en zilte graslanden (buitendijks) } & 0,02\end{array}$

$\begin{array}{ll}\text { H2130A Grijze duinen (kalkrijk) } & 0,02\end{array}$

$\begin{array}{ll}\text { H2120 Witte duinen } & 0,01\end{array}$

$\begin{array}{ll}\text { H2150 Duinheiden met struikhei } & 0,01\end{array}$

H2180Abe Duinbossen (droog), berken-eikenbos $\quad 0,01$

Als de hoogste depositietoename plaatsvindt op een hexagoon waar géén sprake is van een (naderende) stikstofoverbelasting, dan is de hoogste toename op een hexagoon met wel een (naderende) stikstofoverbelasting in deze kolom weergegeven. 


\section{Emissie \\ (per bron) \\ Situatie 1}

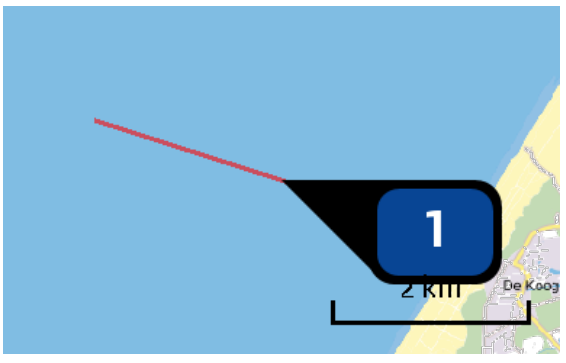

Naam

Locatie $(X, Y)$

Scheepstype

Omschrijving

M/N RAM

Sleepboten,

werkschepen en

overige GT: 100-1599

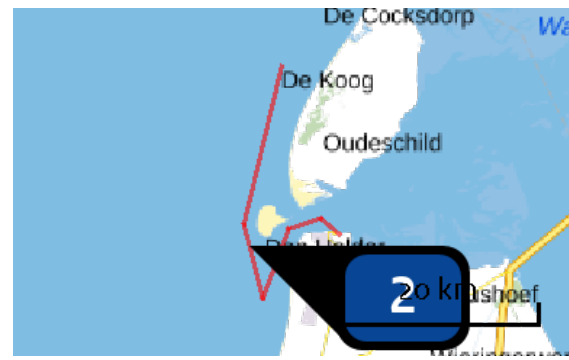

Naam

Locatie $(X, Y)$

NOx

Omschrijving

M/V RAM

Sleepboten,

werkschepen en

overige GT: 100-1599

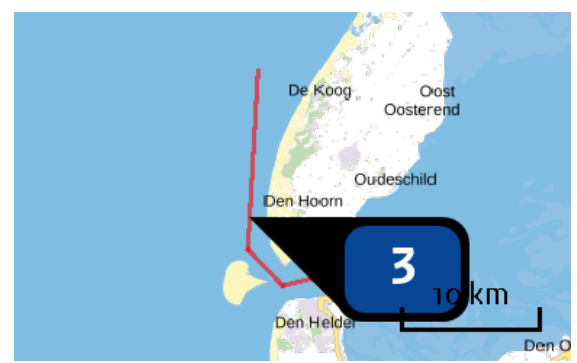

Naam

Locatie $(X, Y)$

NOx

\section{Bron 1}

110797, 569172
Aantal bezoeken Stof

6 / jaar
Emissie

\section{Bron 2}

105765,551846

$33,58 \mathrm{~kg} / \mathrm{j}$
Aantal bezoeken Stof

2/ jaar NOx
Emissie $33,58 \mathrm{~kg} / \mathrm{j}$

Sleepboten,

Empiric

4/jaar NOx

$38,76 \mathrm{~kg} / \mathrm{j}$

Bron 3

108266, 559105

$38,76 \mathrm{~kg} / \mathrm{j}$

overige GT: 100-1599 


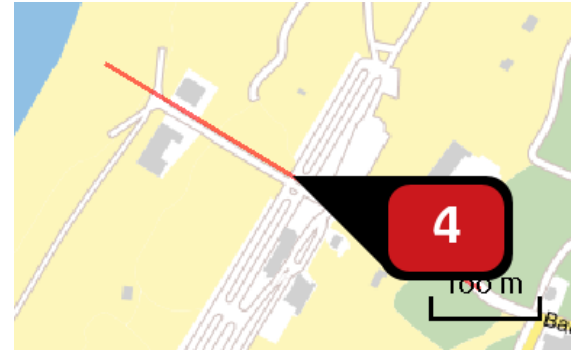

Voertuig

AFW
Omschrijving

Graafmachine
Naam

Locatie $(X, Y)$

NOx

Brandstof verbruik (I/j)
Bron 4

112863,568462

$2,78 \mathrm{~kg} / \mathrm{j}$
Uitstoot hoogte

2,5

4,0

$0,2 \mathrm{NOx}$

$2,78 \mathrm{~kg} / \mathrm{j}$ 
Hoewel verstrekte gegevens kunnen dienen ter onderbouwing van een vergunningaanvraag, kunnen er geen rechten aan worden ontleend. De eigenaar van AERIUS aanvaardt geen aansprakelijkheid voor de inhoud van de door de gebruiker aangeboden informatie. Bovenstaande gegevens zijn enkel bruikbaar tot er een nieuwe versie van AERIUS beschikbaar is. AERIUS is een geregistreerd handelsmerk in Europa. Alle rechten die niet expliciet worden verleend, zijn voorbehouden.

Rekenbasis Deze berekening is tot stand gekomen op basis van:

AERIUS versie 2019A_20200805_f3dee6357e

Database versie 2019A_20200805_f3dee6357e

Voor meer informatie over de gebruikte methodiek en data zie:

https://www.aerius.nl/nl/factsheets/release/aerius-calculator-2019A 
Wageningen Marine Research

T: $+31(0) 317480900$

E: marine-research@wur.nl

www.wur.nl/marine-research

Bezoekers adres:

- Ankerpark 271781 AG Den Helder

- Korringaweg 7, 4401 NT Yerseke

- Haringkade 1, 1976 CP IJmuiden
Wageningen Marine Research levert met kennis, onafhankelijk wetenschappelijk onderzoek en advies een wezenlijke bijdrage aan een duurzamer, zorgvuldiger beheer, gebruik en bescherming van de natuurlijke rijkdommen in zee-, kust- en zoetwatergebieden.
Wageningen Marine Research is onderdeel van Wageningen University \& Research. Wageningen University \& Research is het samenwerkingsverband tussen Wageningen University en Stichting Wageningen Research en heeft als missie: 'To explore the potential of nature to improve the quality of life' 